\author{
UNIVERSIDADE DE SÃO PAULO \\ FACULDADE DE FILOSOFIA, LETRAS E \\ CIÊNCIAS HUMANAS \\ DEPARTAMENTO DE LETRAS CLÁSSICAS E VERNÁCULAS
}

RENATA PALUMBO

\title{
Referenciação e Argumentação: a dinâmica nas orientações argumentativas em debates políticos televisivos
}




\section{Referenciação e Argumentação: a dinâmica nas orientações argumentativas em debates políticos televisivos}

Dissertação apresentada ao Programa de PósGraduação em Filologia e Língua Portuguesa, do Departamento de Letras Clássicas e Vernáculas, da Faculdade de Filosofia, Letras e Ciências Humanas da Universidade de São Paulo, para obtenção de título de Mestre em Letras.

Área de concentração: Língua Portuguesa Orientadora: Profa. Dra. Zilda Gaspar

Oliveira de Aquino

São Paulo 


\section{FOLHA DE APROVAÇÃO}

Renata Palumbo

Referenciação e Argumentação: a dinâmica nas

orientações argumentativas em debates políticos televisivos.

Dissertação apresentada ao Programa de Pós-

Graduação em Filologia e Língua Portuguesa, do Departamento de Letras Clássicas e Vernáculas, da Faculdade de Filosofia, Letras e Ciências Humanas da Universidade de São Paulo, para obtenção de título de Mestre em Letras.

Área de concentração: Língua Portuguesa Orientadora: Profa. Dra. Zilda Gaspar Oliveira de Aquino

Aprovado em:

Banca Examinadora

Profa. Dra.:

Instituição: Assinatura:

Profa. Dra.:

Instituição: Assinatura:

Profa. Dra.:

Instituição: Assinatura: 
A minha mãe (in memoriam) e a meu pai, por dedicarem a mim boa parte de suas vidas. 


\section{AGRADECIMENTOS}

À Professora e Orientadora Dra. Zilda Gaspar Oliveira de Aquino, pela orientação, dedicação, carinho, incentivo e oportunidade de crescimento e de aprendizado.

Às Professoras Dras. Maria Lúcia da Cunha Victorio de Oliveira Andrade e Anna Christina Bentes, pelas sugestões e pela presença, durante o exame de qualificação.

A todos os meus professores do curso de especialização (Lato Sensu) e de mestrado (Stricto Sensu), pelas preciosas aulas.

A meus pais, Angelina e Donato, pela minha vida e pelo apoio em todos os momentos.

À amiga Eliete, pelo companheirismo, força e colaboração.

À Tânia e família, por terem me encorajado e apoiado.

Ao Felipe, pela tradução do resumo desta pesquisa.

À minha família, Regiane, Darcio, Caroline, Beatriz e Vitor, pela presença valiosa em meu caminho.

Aos meus amigos, Melissa, Liliane, Roberta, Silvando, Iramildes, Rogério, Rosana, Beth, Fernanda, pelos momentos especiais nos quais crescemos, somamos, rimos e choramos. 
O governo da palavra não é tudo na política, mas a política não pode agir sem a palavra: a palavra intervém no espaço de discussão para que sejam definidos o ideal dos fins e os meios da ação política; a palavra intervém no espaço de ação para que sejam organizadas e coordenadas a distribuição de tarefas e a promulgação de leis, regras e decisões de todas as ordens; a palavra intervém no espaço de persuasão para que a instância política possa convencer a instância cidadã dos fundamentos de seu programa e das decisões que ela toma ao gerir os conflitos de opinião em seu proveito. 


\section{RESUMO}

PALUMBO, R. Argumentação e Referenciação: a dinâmica nas orientações argumentativas em debates políticos televisivos. 2007. 193f. Dissertação (Mestrado) - Faculdade de Filosofia, Letras e Ciências Humanas, Universidade de São Paulo, São Paulo, 2007.

Esta pesquisa investigou os processos de referenciação do ponto de vista argumentativo, e observou, especificamente, as ocorrências de expressões nominais definidas e indefinidas em discursos produzidos por grupos políticos em situação de debate na televisão. $O$ corpus selecionado compreendeu um debate político organizado pelo programa Roda Viva, transmitido pela TV Cultura de São Paulo, em 15 de julho de 2005, cujos debatedores, deputados e senadores, integrantes da CPI dos Correios, estavam divididos em dois grupos partidários: a oposição, formada por representantes dos partidos PFL, PPS e PSDB, e os governistas, do partido do PT. Estabelecemos em quais condições específicas de produção esse discurso foi elaborado e observamos as características específicas tanto do suporte, quanto do gênero no corpus selecionado. Analisamos a interação entre os debatedores, para observar a seleção lingüística a que cada um deles procedeu para construir determinados referentes, e examinamos o encaminhamento argumentativo que se constituiu na rede referencial. Enfim, investigamos como as orientações argumentativas se construíram de maneira interativa entre os grupos, já que estes, apesar de cumprirem o mesmo papel social na situação interacional, encontravam-se em posições partidárias distintas. Adotamos por referencial teórico: estudos sobre a referenciação, em Mondada e Dubois (2003), Apothéloz (2003), Marcuschi e Koch (1998); reflexões em torno da argumentação, em Perelman e Olbrechts-Tyteca (1958, 2002), Charaudeau (2006) e Aquino (1997); investigações sobre a modalidade falada da língua quanto às questões de interação, em Aquino, Fávero e Andrade (1998) e Marcuschi (2001).

Palavras-chave: argumentação, processos referenciais, debate televisivo, discurso político. 


\begin{abstract}
PALUMBO, R. Argumentation and Referentiation: the dynamic in the argumentative orientations in political media debates. 2007. 193f. Dissertation (Masters) - College of Philosophy, Letters and Human Sciences, University of São Paulo, São Paulo, 2007.

This research investigated the referencial processes from the argumentative point of view, and observed, specifically, the occurrences of nominal expressions in political debates in the media. The corpus consisted of a political debate organized by Roda Viva, a program transmitted by TV Cultura of São Paulo, on July 15 2005, whose participants (politicians) were divided into two groups: the opposition, formed by PFL, PPS and PSDB members, and governmetalists, who belonged to the PT. The particular conditions of production of the participants' discourses were described and the specific characteristics of both the support and the genre were observed. The analysis of the interaction between the participants was carried out in order to observe the linguistic selection that each one of them used to construct the textual referents, and to examine the argumentative orientation that was established in the referencial net. At last, we investigated how the argumentative orientations were constructed interactively by the groups, since they, in spite of having the same social role, took opposite stands. The adopted bibliographical references were: studies on the referentiation, in Mondada and Dubois (2003), Apothéloz (2003), Marcuschi and Koch (1998); reflections upon argumentation, in Perelman and Olbrechts-Tyteca (1958, 2002), Charaudeau (2006) and Aquino (1997) stand out; inquiries on spoken language, specially concerning interaction questions, in Aquino, Fávero and Andrade (1998) and Marcuschi (2001).
\end{abstract}

Key-words: argumentation, referencial processes, media debates, political discourse. 


\section{LISTA DE ILUSTRAÇÕES}

Figura 01 - Abertura do programa Roda Viva: a logomarca ................. 32

Figura 02 - Abertura do programa Roda Viva:

a logomarca remete a um alvo ......................................................... 32

Figura 03 - Alvo do programa: o mar de lama .................................... 33

Figura 04 - Charge a respeito da situação política ................................. 38

Figura 05 - Cenário do programa ........................................................ 111 


\section{LISTA DE TABELAS}

Quadro 01 - Normas utilizadas na transcrição do corpus

Quadro 02 - Representação da hipótese do trabalho

Quadro 03 - Processo da construção do acontecimento na mídia

Quadro 04 - Corredores isotópicos de Blikstein

Quadro 05 - Representação do exórdio do programa Roda Viva 109

Quadro 06 - Comparação de seleções lingüísticas sobre o presidente ..

Quadro 07 - Seleções lingüísticas dos políticos da oposição a respeito dos petistas acusados de corrupção

Quadro 08 - Seleções lingüísticas dos políticos do governo a respeito dos petistas acusados de corrupção

Quadro 09 - Seleções lingüísticas dos políticos da oposição a respeito de Roberto Jefferson

Quadro 10 - Seleções lingüísticas dos políticos da oposição a respeito de Marcos Valério 


\section{SUMÁRIO}

\section{CONSIDERAÇÕES INICIAIS}

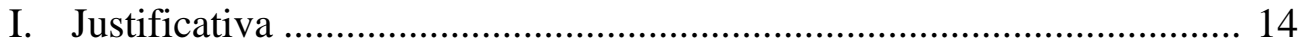

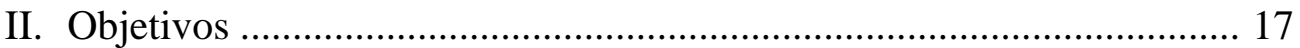

III. Procedimentos metodológicos ........................................................... 18

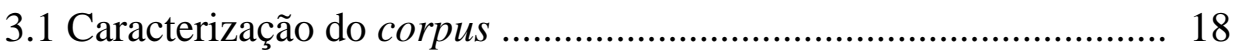

3.1.1 O programa Roda Viva .................................................... 20

3.1.2 O momento histórico da política brasileira ........................... 22

3.1.3 A Comissão Parlamentar de Inquéritos (CPI) ....................... 22

3.2 Tratamento do corpus ............................................................... 24

3.3 Esquema e unidade de análise .................................................... 25

IV. Organização do trabalho ................................................................. 27

\section{CAPÍTULO I}

\section{O discurso (de) político na mídia televisiva}

1.1 As condições de produção das práticas discursivas na televisão .......... 30

$1.2 \mathrm{O}$ gênero debate televisivo .............................................................. 40

1.2.1 O discurso (de) político em situações de

debate na televisão ......................................................................... 42

1.3 A posição ideológica e o jogo discursivo ........................................... 46

1.3.1 A situação discursiva entre grupos (de) políticos ....................... 50

\section{CAPÍTULO II}

\section{A dimensão argumentativa do discurso (de) político}

2.1 A argumentação como atividade discursiva, interativa e criativa ......... 54

2.2 A Retórica aristotélica e a retomada da argumentação

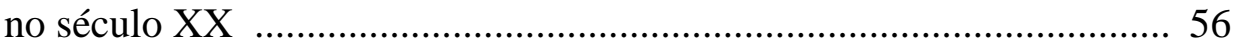

2.3 A construção de sentido como importante

processo da argumentação .............................................................. 61

2.4 O papel da argumentação no discurso (de) político ............................. 70

2.5 A apresentação do referente como escolha argumentativa ................... 74 


\section{A referenciação como processo constitutivo de orientações argumentativas}

3.1 A referenciação como construção discursiva de realidade ................. 80

3.2 A estratégia referencial e as orientações argumentativas ................... 84

3.2.1 A seleção de expressões nominais

como estratégia argumentativa ...................................................... 86

3.2.2 A metáfora como recurso argumentativo .................................. 92

3.2.2.1 As expressões de uso metafórico ................................... 95

3.2.2.2 A metáfora e os efeitos argumentativos ........................ 96

3.2.2.3 A metáfora nos processos de referenciação .................... 98

3.3 A importância da cognição situada nas orientações argumentativas ... 102

3.4 A dinâmica na construção de referentes nos debates

políticos televisivos: o jogo argumentativo 105

\section{CAPÍTULO IV}

\section{Análise dos processos referenciais e de suas orientações argumentativas nos debates políticos}

4.1A organização do programa: o exórdio ............................................. 108

4.2A construção conjunta da imagem do presidente ............................ 118

4.2.1 A construção pelo grupo da oposição ..................................... 120

4.2.2 A construção pelo grupo do governo .................................... 124

4.3 A dinâmica na "fabricação" dos acusados de corrupção ................. 128

4.3.1 Os petistas ...................................................................... 130

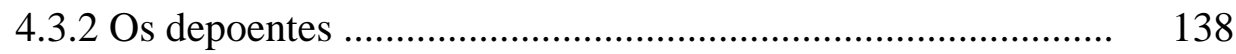

4.4 As (não) verdades de cada um: a disputa de "realidades” ............... 143

4.5 Conclusão das análises ................................................................ 150

CONSIDERAÇÕES FINAIS _................................................................ 156

REFERÊNCIAS BIBLIOGRÁFICAS ...................................................... 160

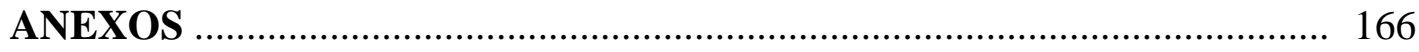




\section{Justificativa}

Entre as investigações que têm como objetos a língua e o discurso, o problema da referência vem ocupando um espaço significativo, tanto nas áreas da linguagem, quanto nas reflexões filosóficas, sociológicas, lógicas e psicológicas.

Muitas das reflexões abordaram, e ainda abordam, a questão da referência do ponto de vista da correspondência entre a língua e o mundo. Entre elas, a perspectiva das metáforas do espelho, do reflexo e do mapeamento considera a ação de referir uma representação adequada da realidade (Rorty, 1980), e avalia a sintaxe em relação à sua capacidade de cartografar a ordem natural das coisas. (Padley, 1985; Cohen, 1977; Grace, 1987)¹.

Essas posições vêm sendo questionadas, atualmente, por correntes que adotam uma perspectiva interacionista, sociocognitivista e discursiva, as quais privilegiam não mais a ligação palavras e coisas, mas sim as relações sujeito, percepção, mundo e língua.

Nessa perspectiva atual, assumida neste trabalho, vários fatores são considerados significativos nos estudos das atividades discursivas, em que os sujeitos criam realidades textuais, tais como: a intersubjetividade, a heterogeneidade, a argumentatividade da língua etc. Dessa maneira, a configuração teórica pode centrar-se em vários domínios de estudos: os semânticos, os pragmáticos, os textuais, os conversacionais, os argumentativos, entre outros.

Como é possível perceber, é vasto o campo de abordagem sobre a questão da referência. O foco de atenção do nosso trabalho versou sobre uma das várias implicações dessa área de estudo, a que diz respeito aos processos referenciais do ponto de vista argumentativo na modalidade falada da língua, em interações face a face em que dois grupos

\footnotetext{
${ }^{1}{ }^{1}$ Veja-se em MONDADA, L.; DUBOIS, D. (2003). Construção dos objetos de discurso e categorização: Uma abordagem dos processos de referenciação. In. CAVALCANTE, M. M.; RODRIGUES, B.B.; CIULLA, A. (org.). Clássicos da Lingüística 1. Referenciação. São Paulo: Contexto, p. 17-52.
} 
políticos - representantes do governo e da oposição - encontravam-se em situação de debate na televisão.

Nossa preocupação voltou-se para a maneira como os políticos apresentaram determinados referentes textuais por meio de seleções lingüísticas (expressões nominais) que, além de possibilitarem a progressão do texto e da interação, também fizeram parte do jogo discursivo-argumentativo instaurado entre esses sujeitos sociais.

Embora já soubéssemos da existência de muitos trabalhos significativos sobre a referenciação - destacamos os de Koch (1996, 2001, 2003, 2005, 2006), Koch e Marcuschi (1998), Apothéloz (2003), Marcuschi (2000, 2001, 2002), Mondada (2001, 2005), Mondada e Dubois (2003), entre outros. Verificamos que muito ainda era necessário investigar no que concerne ao fenômeno da referência associado ao campo da argumentação, especialmente na modalidade falada da língua, pois esta comporta elementos específicos que exigem ações coordenadas e cooperativas que transpassam a simples capacidade lingüística dos interactantes.

Dessa maneira, encaminhamos nossa pesquisa conforme o pressuposto de que o teor argumentativo das palavras e das expressões não se limita ao campo de estudo da seleção lexical, pois a atitude argumentativa não se encerra nas palavras em si, mas nas relações que elas têm na prática enunciativa, no momento de troca e nas regras estabelecidas socialmente.

Por esse motivo, o ponto em questão não foi a seleção lingüística em si, mas como ela, associada a outras, poderia estabelecer uma linha referencial capaz de "fabricar" sentidos e modificar contextos de maneira que as imagens construídas desse processo resultassem em elementos significativos para as teses defendidas pelos políticos na situação de interação.

Sobre esse ponto, quando falamos em argumentação no campo da política, partimos do pressuposto de que o debate político televisivo é, por excelência, o lugar das disputas 
argumentativas e, neste sentido, seguimos a orientação teórica de estudiosos, como Aquino, 1997 e Charaudeau, 2006b. É significativo lembrar que o próprio encontro propõe esse jogo, pois as diversas posições ideológicas fazem os políticos direcionarem olhares distintos sobre os assuntos abordados. Ainda, incluímos nesse quadro o fato de que, se a mídia possibilita esses encontros, ela o faz de maneira a provocar um acontecimento, por meio de vários fatores específicos do suporte e do gênero em questão (Charaudeau, 2006a).

Assim, os estudos da argumentação - a partir de Perelman e Olbrechts-Tyteca (1958, 2002), Aquino (1997, 2005), Koch (2005), entre outros - ligados aos da referenciação - Koch e Marcuschi (1998), Apothéloz (2003), Marcuschi (2000, 2001, 2002), Mondada (2001, 2005), Mondada e Dubois (2003), Francis (2003), Conte (2003), entre outros - possibilitaram uma visão da configuração argumentativa em seu modo dinâmico, como se instaura nos debates políticos transmitidos pela televisão, tanto na observação da linha referencial constituída nos enunciados pelos grupos políticos em posições ideológicas distintas, quanto no exame dos fatores contextuais implicados na organização midiática do encontro.

De maneira geral, ao conceber que a atividade argumentativa está presente nos processos referenciais e que ambos fazem parte do complexo sistema de interação humana em práticas socialmente estabelecidas, buscamos investigar sobre a organização da língua e do discurso e sobre a relação dos sujeitos com o mundo, a partir dos seguintes questionamentos:

o Como se constitui a construção referencial, especialmente nas interações face a face, em situações de debate transmitidas pela mídia televisiva?

o Como os processos referenciais, por meio de expressões nominais definidas e indefinidas, direcionam orientações argumentativas em discursos elaborados por políticos de partidos diversos? 
o Como se marcaram as posições ideológicas de grupos no processo referencialargumentativo?

o De que modo as condições específicas de produção podem intervir na construção do referente e no direcionamento argumentativo?

Tais questionamentos propiciaram a formulação dos objetivos de nosso trabalho, explicitados a seguir.

\section{Objetivos}

\section{Geral}

o Contribuir para as investigações sobre os estudos da referência e da argumentação na modalidade falada da língua, veiculada nos meios midiáticos.

\section{Específicos}

o Observar a configuração dos processos referenciais nos discursos políticos em situação de debate na televisão.

o Analisar a constituição de orientações argumentativas nas ocorrências de expressões nominais.

o Detectar a dinamicidade na construção do referente textual e na orientação argumentativa entre grupos políticos partidários.

o Examinar a influência das condições específicas de produção no direcionamento da interação e na construção avaliativa-argumentativa do referente. 


\section{Procedimentos metodológicos}

\subsection{Caracterização do corpus}

Selecionamos, da mídia televisiva, um debate político televisivo, o qual foi transmitido ao vivo pelo programa Roda Viva de São Paulo, veiculado pela TV Cultura, em 15 de julho de 2005. O debate teve duração de aproximadamente 1 hora e 25 minutos e abordou questões a respeito da crise do governo federal e das denúncias de corrupção ocorridas no ano em que o debate foi produzido.

Nesse programa, além do jornalista e mediador Paulo Markun (que será identificado nas análises pelas iniciais P.M.), estavam presentes seis debatedores, sendo que todos eram, na ocasião, integrantes da CPI Mista dos Correios; entretanto, dividiam-se em dois pólos políticos: os governistas (PT) e a oposição (PFL, PPS, PSDB).

O debate organizou-se em quatro blocos e foram apresentadas cinco perguntas. Cada participante teve o direito à resposta, totalizando seis pareceres para cada questão. Esses foram intercalados entre grupos partidários.

Em relação aos debatedores, entendemos ser necessário conhecer seus partidos, profissões, mandatos e formação ${ }^{2}$ :

\section{José Eduardo Cardozo (J.E.C.)}

Partido: PT, São Paulo.

Profissões: Advogado e Professor Universitário.

Mandatos: Vereador (1995-1996) São Paulo, SP, PT; Vereador (1997-2000), São Paulo, SP, PT; Vereador (2001-2003), São Paulo, SP, PT; Deputado Federal (20032007), SP, PT; Deputado Federal (2007-2011), SP, PT.

\footnotetext{
22 Informações obtidas nos seguintes sites: http:// www.camara.gov.br, http://www.senado.gov.br; http://www.ideli.com.br (último acesso em 03/12/2007).
} 
Formação: Direito (1977-1981) pela PUC de São Paulo; Mestrado (1982-1993) em Direito Civil pela PUC de São Paulo; Doutorado incompleto (1994) em Direito Administrativo pela PUC de São Paulo.

\section{o Ideli Salvatti (I.S.)}

Partido: PT, Santa Catarina.

Profissão: Professora efetiva do quadro do Magistério Estadual/SC, desde 1983.

Mandatos: Deputada Estadual (1994-1998, 1998-2002), Santa Catarina, PT; Senadora (2002-2006, 2007-2011), Santa Catarina, PT.

Formação: licenciatura em Física pela Universidade Federal do Paraná.

\section{o Maurício Rands (M.R.)}

Partido: PT, Pernambuco

Profissões: Advogado e Professor Universitário

Mandatos: Deputado Federal (2003-2007), Pernambuco, PT; Deputado Federal (2007-2011), Pernambuco, PT.

Formação: Direito (1979-1982) pela Universidade Federal de Pernambuco; PósGraduação em Direito do Trabalho e Relações Industriais (1990-1991), Università di Bari, Itália; Mestrado em Políticas Públicas na América Latina (1991-1992), University of Oxford, Inglaterra; Doutorado em Política (1992-1996), University of Oxford, Inglaterra.

\section{o César Borges (C.B.)}

Partido: PFL, Bahia.

Profissão: Engenheiro Civil e Empresário.

Mandatos: Vice-Governador (1998), Bahia, PFL; Governador (1998-2002), Bahia, PFL; Senador (2003-2007, 2007-2011), Bahia, PFL. 
Formação: Engenharia Civil pela Universidade Federal da Bahia.

\section{o Denise Frossard (D.F.)}

Partidos: PPS, Rio de Janeiro (1998-1999, 2004-2007); PSDB (2001-2004).

Profissão: Advogada, Juíza, Redatora e Professora Universitária.

Mandatos: Deputada Federal (2003-2007), Rio de Janeiro, PPS.

Formação: Direito pela Pontifica Universidade Católica do Rio de Janeiro.

\section{o Gustavo Fruet (G.F.)}

Partidos: PMDB, 1991-2004; PSDB, 2005.

Profissão: Advogado.

Mandatos: Vereador (1997-1999), Curitiba, PR, PMDB; Deputado Federal (19992003), PR, PMDB; Deputado Federal (2003-2007), PR, PMDB; Deputado Federal (2007-2011), PR, PSDB.

Formação: Direito pela Universidade Federal do Paraná (UFPR), 1982-1986; Especialização em Direito Penal, UFPR, 1989; Mestrado em Direito Público, UFPR, 1991-1994; Doutorado em Direito das Relações Sociais, UFPR, 1996-1997.

\subsubsection{O programa Roda Viva}

O Roda Viva consolidou-se como uns dos mais tradicionais programas de entrevistas da televisão brasileira. Em seus 21 anos de exibição, com mais de mil edições, muitos foram os temas abordados, principalmente aqueles voltados às questões políticas, culturais e econômicas. Durante esse tempo, ele contou com a presença de importantes personalidades, ou especialistas, nacionais e internacionais.

Além de ser transmitido pela TV Cultura, nacionalmente, o programa é exibido pela TV Educativa do Rio Grande do Sul e por outras redes de televisão, via satélite ou cabo. 
Como também, é possível assistir ao Roda Viva no site http://www.tvcultura.com.br/rodaviva/ ou na rádio Cultura AM-120.

No cenário do programa, há uma cadeira giratória localizada no centro do estúdio, posição esta reservada ao entrevistado da noite. Ao seu redor, estão posicionados, em círculo, o mediador do programa e os entrevistadores.

Além do mediador, também há outro participante, o desenhista Paulo Caruzo. Suas charges são criadas segundo o andamento da entrevista, satirizando os participantes, enquanto eles interagem. Ao mesmo tempo, além de levar humor, os desenhos comportam críticas, possivelmente pela especificidade do próprio gênero "charge” ancorada ao estilo do programa.

Apesar de ser formatado para entrevistas em que apenas um convidado se apresenta por noite, nos últimos anos, o programa Roda Viva vem promovendo debates especiais (o que selecionamos para constituir o corpus de nosso trabalho), em que o enfoque não é o entrevistado, mas os tópicos selecionados, sempre voltados às questões econômicas, culturais e políticas. Isso aconteceu, principalmente no período de junho a dezembro de 2005, momento pelo qual ocorria uma crise política federal provocada por várias denúncias de corrupção as quais envolviam importantes nomes do governo.

O cenário dos programas, com formato de debates, permanece com a mesma configuração em relação aos de entrevista, destacando-se que, no debate selecionado como nosso corpus para análise, a cadeira do entrevistado desapareceu, e foi colocada lama, com várias pegadas, em seu lugar, fazendo com que o alvo dessa edição fosse a crise e a corrupção, encerrando uma imagem pejorativa ao tópico.

A respeito do nome do programa e de seu slogan (Roda Viva: o Brasil passa por aqui), se lembrarmos da história do jornalismo, dos momentos de opressão ocorridos nas décadas de 
60 a 80, sobretudo da questão da liberdade de imprensa, é possível pensarmos em uma ligação com a peça teatral "Roda Viva” escrita por Chico Buarque e estreada em 1968. A peça tornou-se símbolo contra a ditadura militar e a censura dos palcos dos teatros brasileiros. O próprio termo rodaviva, no dicionário Aurélio, refere-se à ação de movimentar, correr, fazer acontecer.

\subsubsection{O momento histórico da política brasileira}

No ano de 2005, questões políticas, como a corrupção e a crise do governo, tornaramse temas freqüentes na mídia brasileira. O começo de tudo isso se deu com as denúncias de corrupção na Empresa Brasileira de Correios e Telégrafos. A divulgação de uma gravação, em que o ex-chefe do departamento de contratação e administração de material do ECT, Maurício Marinho, aparece recebendo três mil reais para facilitar a licitação de uma empresa, iniciou uma série de denúncias envolvendo nomes de políticos, como o do ex-deputado federal Roberto Jefferson que, para se defender das acusações, acusou o governo de pagar trinta mil reais a parlamentares da base aliada em troca de votos favoráveis no Congresso.

Após esse primeiro episódio, instalou-se uma crise política que causou demissões e renúncias de alguns ministros e de vários membros do PT, envolvidos no chamado “mensalão”. Assim, foram abertas várias CPIs (Comissões Parlamentares de Inquéritos), como a dos Correios, dos Bingos, entre outras. Muitas delas foram transmitidas por emissoras de televisão aberta, tornando-se possível acompanhar o desdobramento dos fatos.

\subsubsection{A Comissão Parlamentar de Inquéritos (CPI)}

A Comissão Parlamentar de Inquéritos surgiu na Inglaterra do século XVI, em razão da necessidade de os representantes da população (o poder Legislativo) controlarem os atos praticados por seus governantes (poder Executivo). 
Essas comissões chegaram ao Brasil apenas no século XX, em torno da década de 30, e foram inseridas na Constituição. Vinte anos mais tarde, a CPI Federal foi regulamentada pela lei 1.579, sendo aprimorada em 1988.

Como já diz o nome, a comissão é formada por parlamentares; quando federal, deputados federais ou senadores; quando estadual, deputados estaduais; quando municipais; vereadores. Os participantes são reunidos com o propósito de investigar determinados indícios de ato ilegal, como possíveis irregularidades na administração pública.

Vale lembrar que, no Brasil, controlar a administração pública é também papel dos Tribunais de Contas, que realizam a análise financeira dos gastos dos governantes.

Frisamos que há uma diferença entre CPI e CPMI, pois, nesta última comissão, deputados federais e senadores podem tomar parte. Geralmente, uma CPMI é aberta quando a questão a ser investigada é de grande repercussão, pois não é tarefa fácil conseguir sua abertura, já que é preciso da aprovação de um terço das duas casas (Câmara dos Deputados e Senado Federal).

Ainda, há regras para a formação de uma CPI, ou CPMI: a composição deve respeitar a proporcionalidade dos partidos que compõem a casa, todos os atos, interrogatórios e investigações devem ser registrados por escrito e é preciso de um tema objetivo.

Ressaltamos que uma Comissão Parlamentar de Inquéritos não tem poder para julgar ou condenar. Assim, o relator, depois de ter seu relatório aprovado pelos membros, encaminha-o ao Ministério Público encarregado de abrir um processo judicial. Além disso, a CPI não é autorizada a investigar o Presidente da República e nem pode obrigar uma pessoa a depor; apenas convidar. 


\subsection{Tratamento do corpus}

Selecionado o corpus, o material foi transcrito segundo as normas instituídas pelo Projeto NURC/SP (Preti, 1999, p.12-13). Acrescentamos a essas normas também os elementos não-verbais presentes na interação, como entonações, gestos, olhares e outros.

As normas utilizadas foram as seguintes:

\begin{tabular}{|c|c|}
\hline Ocorrências & Sinais \\
\hline Incompreensão de palavras ou segmentos & ( ) \\
\hline Hipótese do que se ouviu & (hipótese) \\
\hline $\begin{array}{l}\text { Truncamento (havendo homografia, usa-se acento } \\
\text { indicativo da tônica e/ou timbre). }\end{array}$ & / \\
\hline Entonação enfática & Maiúscula \\
\hline $\begin{array}{l}\text { Prolongamento de vogal e consoante } \\
\text { (como s, r). }\end{array}$ & ::podendo aumentar para::: ou mais \\
\hline Silabação & - \\
\hline Interrogação & $?$ \\
\hline Qualquer pausa & ... \\
\hline Comentários descritivos do transcritor & ((minúscula)) \\
\hline $\begin{array}{l}\text { Comentários que quebram a seqüência temática da } \\
\text { exposição; desvio temático }\end{array}$ & --- \\
\hline Superposição, simultaneidade de vozes & [ ligando as linhas \\
\hline $\begin{array}{l}\text { Indicação de que a fala foi tomada ou } \\
\text { interrompida em determinado ponto. Não no seu } \\
\text { início, por exemplo. }\end{array}$ & $(\ldots)$ \\
\hline $\begin{array}{l}\text { Citações literais ou leituras de textos, durante a } \\
\text { gravação }\end{array}$ & “citação” \\
\hline
\end{tabular}


Outras observações (Preti, 1999, p.13) também foram seguidas:

1. Iniciais maiúsculas: só para nomes próprios ou para siglas (USP etc.).

2. Fáticos: ah, éh, ahn, ehn, uhn, tá (não por está: tá? Você está bem?).

3. Números: por extenso.

4. Não se indica o ponto de exclamação (frase exclamativa).

5. Não se anota cadenciamento da frase.

6. Podem-se combinar sinais. Por exemplo: oh::.... (alongamento e pausa).

7. Não se utiliza sinais de pausa, típicos da língua escrita, como ponto-e-vírgula, ponto final, dois pontos, vírgula. As reticências marcam qualquer tipo de pausa.

A transcrição (em anexo) foi apresentada da seguinte maneira: na primeira coluna, do lado esquerdo, numeramos as linhas (em intervalos de cinco linhas); em seguida, identificamos os falantes por meio de siglas (iniciais do nome); por último, transcrevemos os enunciados.

\subsection{Esquema e unidade de análise}

Anteriormente às investigações, organizamos um esquema de análise; para tanto, partimos da hipótese de que a situação de interação do corpus selecionado - debate político televisivo - propiciaria uma divisão partidária/ideológica entre os debatedores: o grupo da oposição e o do governo. Essa polarização influenciaria nos processos referenciais, fazendo que a (re) construção de objetos de discurso e a orientação argumentativa tendessem a ser efetuadas de maneira dinâmica e colaborativa entre grupos. Dessa maneira, os políticos da oposição construiriam imagens de seus referentes textuais, cooperando com o ponto de vista e/ou os interesses do seu grupo, conforme a ação e reação dos outros participantes (governistas); e vice-versa. 
Pressupomos que os políticos de cada grupo também direcionariam efeitos de sentido conjuntamente, conforme o encaminhamento dado pelos participantes e pelo programa. Ainda, consideramos que, por se tratar de um programa televisivo, toda a ação linguageira levaria em conta o auditório em questão: o telespectador, foco de atenção dos políticos e do programa.

A seguir, apresentamos um quadro representativo da hipótese mencionada, já dividida em relação a nossa unidade de análise (expressões nominais definidas e indefinidas com função referencial):

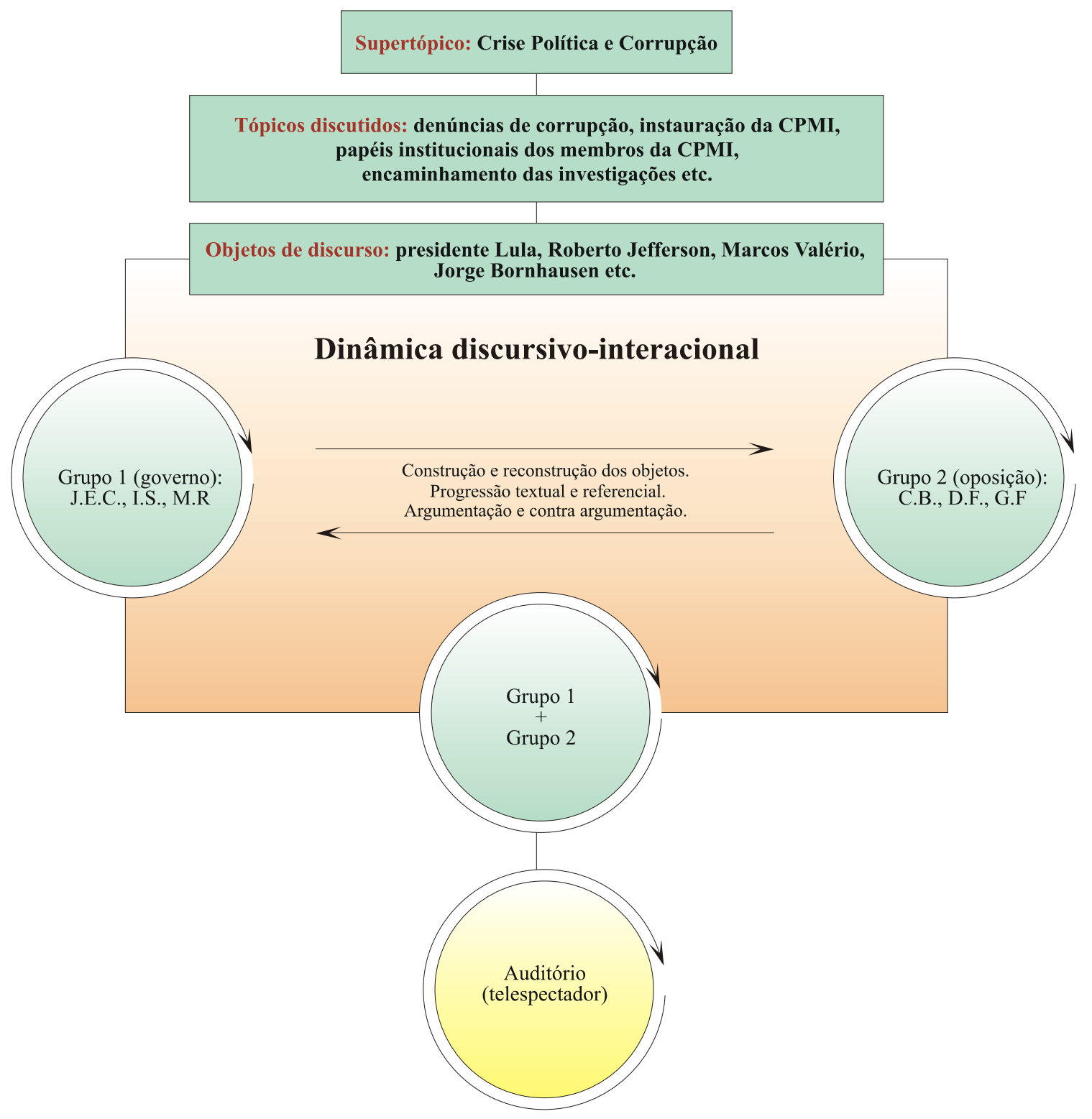


Nosso esquema de análise obedeceu aos seguintes passos: no primeiro momento, observamos todo o processo interacional e depreendemos alguns referentes (re)ativados de maneira recorrente ou significativa pelos debatedores políticos. Foram eles: o presidente Lula, o Roberto Jefferson, os petistas acusados de corrupção, entre outros; em seguida, passamos à análise da (re)construção desses objetos efetivada por cada grupo político. Finalmente, comparamos como cada grupo direcionou o sentido, orientou-o argumentativamente por meio do processo de referenciação.

Ainda, durante as análises, tornou-se necessário examinar e destacar: alguns momentos da interação em que os discursos ou posições dos próprios debatedores foram avaliados e (des)qualificados por meio de encapsulamentos e rótulos metadiscursivos; a influência da organização do programa, tais como: o título do debate, o cenário, a apresentação dos debatedores, entre outros.

\section{Organização do trabalho}

Este trabalho encontra-se organizado nas seguintes partes:

o Considerações iniciais: justificativa, objetivos do trabalho, procedimentos metodológicos (caracterização e tratamento do corpus, esquema e unidade de análise).

\section{o Capítulo I - O discurso (de) político na mídia televisiva}

Levantamento de teorias sobre os discursos políticos na mídia televisiva e sobre os gêneros midiáticos, em especial, os debates na televisão. Neste capítulo, apontamos os elementos discursivos e extradiscursivos que configuram o debate político 
televisivo, inserindo-o em um campo discursivo propenso a disputas ideológicas e confrontos de idéias.

o Capítulo II - A dimensão argumentativa do discurso (de) político Apresentação do jogo argumentativo e interacional presente no debate político televisivo, e dos recursos lingüísticos e seus valores argumentativos.

o Capítulo III - A referenciação como processo construtivo e dinâmico de orientações argumentativas

Estudo dos processos referenciais, em ocorrências de expressões nominais, relacionando-o às questões argumentativas, em interações face a face.

o Capítulo IV - Análise dos processos referenciais e suas orientações argumentativas nos debates políticos

Exame do corpus selecionado conforme os objetivos deste trabalho, utilizando os pressupostos teóricos discutidos nos capítulos I, II e III.

o Considerações finais: retomada dos objetivos e interpretação dos dados obtidos na análise.

o Anexos: transcrição do corpus e DVD. 


\section{CAPÍTULO I}

O discurso (de) político na mídia televisiva 
O discurso político é, por excelência, o lugar de um jogo de máscaras. Toda palavra pronunciada no campo político deve ser tomada ao mesmo tempo pelo o que ela diz e não diz. Jamais deve ser tomada ao pé da letra, numa transparência ingênua, mas como resultado de uma estratégia cujo enunciador nem sempre é soberano.

Patrick Charaudeau

Antes de iniciarmos os estudos a respeito do discurso (de) político em situação de debate na mídia televisiva, é de extrema importância observarmos tanto o lugar em que são construídos os enunciados, quanto as múltiplas finalidades que englobam o espaço da interação. Isso nos permite dizer que não só a dinâmica entre enunciados produzidos por políticos, em determinados encontros, resulta em efeitos de sentido, mas também a interrelação instaurada entre os discursos desse grupo social aliado ao suporte e ao gênero em que esses estão inseridos.

Para esse propósito, discutiremos, nos subitens 1.1 e 1.2, os estudos de Charaudeau (2006a, 2006b) a respeito dos gêneros discursivos midiáticos, especificamente às questões voltadas aos debates televisivos, e as investigações de Aquino (1997, 2005) sobre o discurso de políticos na televisão. Isso não quer dizer que não tenhamos observado o posicionamento de outros autores como Marcuschi (2002b), Bakhtin (1992), Chilton (2004); entretanto, privilegiaremos os dois primeiros estudiosos por dedicarem boa parte de suas pesquisas às investigações a respeito das práticas discursivas de políticos na mídia ligadas à argumentação.

\subsection{As condições de produção das práticas discursivas na televisão}

Observar o discurso é ir além da língua, é analisar as regras de seu uso. Nenhum discurso é produzido fora de circunstâncias específicas, ou seja, falamos ou escrevemos dentro de um espaço em que levamos em consideração aquele para quem o discurso se dirige, 
a relação dos participantes, os objetivos do encontro. E são, também, nessas condições extradiscursivas e interativas que os sentidos são constituídos.

Charaudeau (2006a, p.204), ao estudar o discurso das mídias, considera três elementos determinantes de um gênero discursivo: o grau de generalidade das características que definem a classe textual, o modo de organização textual e o lugar de construção de sentido.

O grau de generalidade das características textuais corresponde à organização textual (macro e micro estrutural), e às relações interativas, de trocas sociais. Ao reportar-se às trocas, o autor faz menção à classificação de Bakhtin (1992), sobre os gêneros primários (circulação social ampla) e os gêneros secundários (restrita circulação social), que um é assimilado pelo outro.

Além disso, as modalidades da língua, a falada, a escrita e suas interligações, explicitam as variadas maneiras de materialização do discurso em determinadas situações de produção. Charaudeau (2006a) ainda ressalta que quanto mais gerais forem as características textuais, menos são discriminantes. Por outro lado, quando são específicas, podem indicar traços definidores de um tipo de texto.

A segunda característica corresponde à organização dos enunciados; estes podem-se compor de maneira a se apresentarem como descritivos, narrativos, argumentativos. É possível dizer que, na composição textual, todos esses elementos podem aparecer conjuntamente, mesmo que um deles seja dominante, em relação aos outros.

Em relação ao lugar de construção de sentido do texto, terceiro fator que determina o gênero discursivo, Charaudeau (2006a) afirma que há três fatores implicados: o lugar de produção, o lugar de recepção e o lugar do produto acabado. 
Quanto ao primeiro, se pensarmos nos programas transmitidos pela televisão, observaremos que os enunciados são produzidos e inseridos em cenários ${ }^{3}$, ou seja, em espaços construídos por produtores, com o auxílio de recursos tecnológicos e visuais que resultam em encenações ${ }^{4}$ e em efeitos de sentido. Tomemos como exemplo o seguinte cenário (figuras 1, 2 e 3) construído no programa Roda Viva, cujo corpus selecionamos para análise neste trabalho:

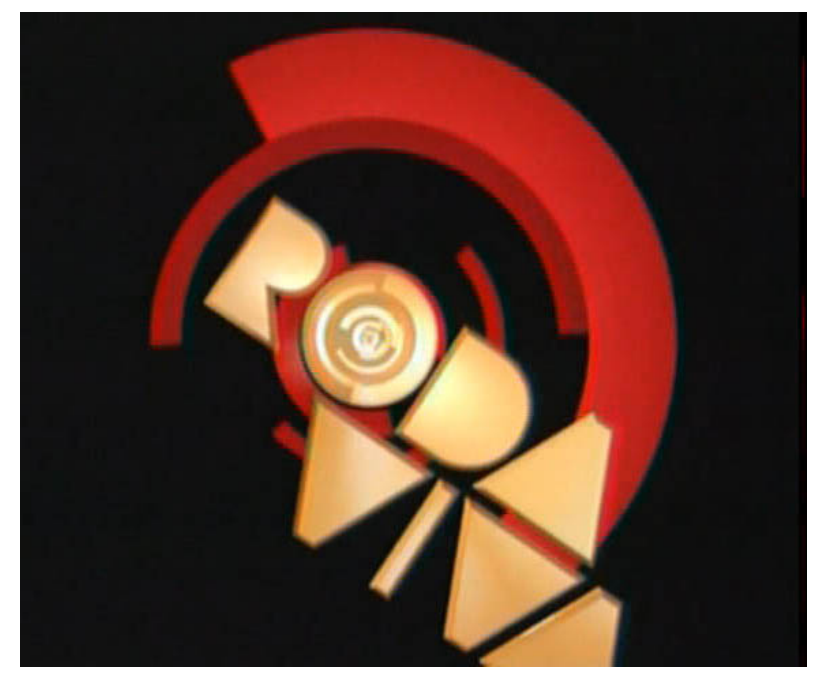

Fig.01. Abertura do programa Roda Viva: a logomarca.

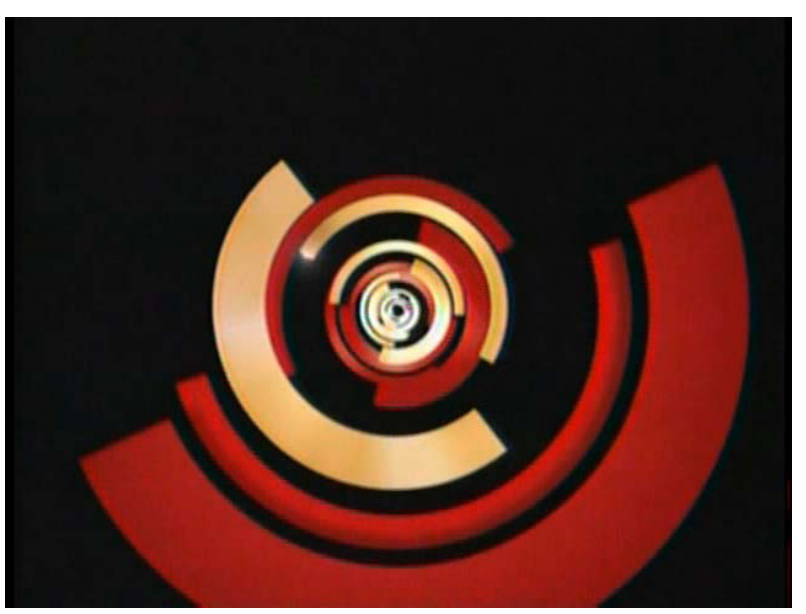

Fig.02. Abertura do programa Roda Viva: a logomarca remete a um alvo.

\footnotetext{
${ }^{3}$ Termo utilizado por Charaudeau (2006a) para designar a situação instaurada nos programas midiáticos.

${ }^{4}$ Outro termo utilizado pelo autor, referindo-se que nessas práticas há uma simulação de realidade, de verdade.
} 


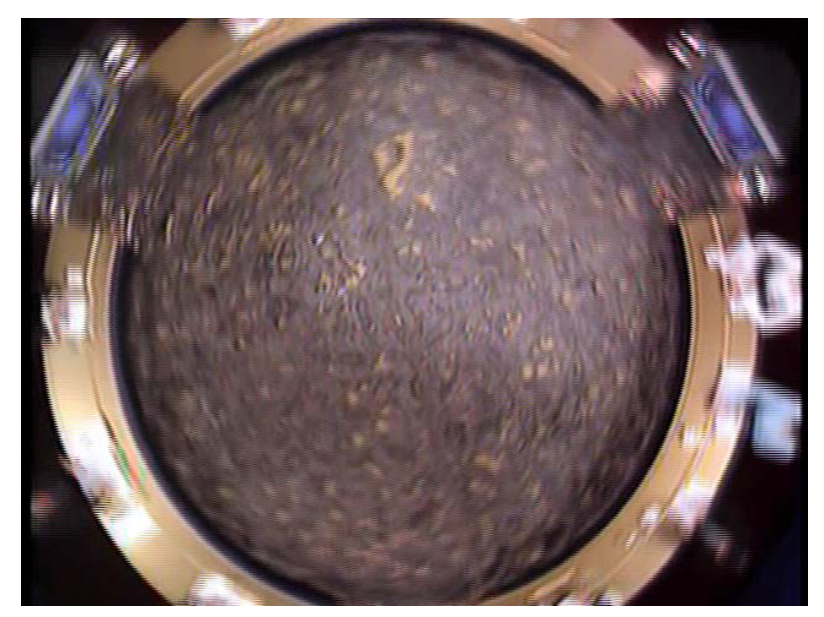

Fig.03. Alvo do programa: o mar de lama

O título “Crise Política e Corrupção” é apresentado como alvo desse debate especial promovido pelo programa Roda Viva, como é possível observar em seu cenário ${ }^{5}$ (figuras 01 , 02 e 03). O direcionamento dado à questão da corrupção na política brasileira é efetivado pela representação de um mar de lama, remetendo valores negativos às situações que serão discutidas durante o debate. Esse espaço é construído de maneira a constituir sentidos que irão influir na situação discursiva.

Já o lugar da recepção reporta-se, especificamente, a quem o discurso é direcionado, ou seja, às pessoas que assistem a programas de televisão e com ele interagem, por meio de um aparelho eletrônico, neste caso, a televisão.

O terceiro fator referente ao lugar de construção de sentido do texto corresponde ao que Charaudeau (2006a) denominou produto acabado. Este se relaciona ao texto e aos efeitos de sentido resultantes dos dois fatores anteriormente esboçados, isto é, à relação entre o lugar de produção (instância midiática), em que discursos são fabricados e inseridos em cenários, e o lugar de recepção (audiência), em que os textos são reconhecidos e interpretados. O estudioso afirma que (2006a, p.204-205):

\footnotetext{
${ }^{5}$ Como indicamos à pagina 21 deste trabalho, o cenário foi produzido especialmente para esse programa com formato de debate, pois o Roda Viva caracteriza-se por ser um programa de entrevistas.
} 
O lugar de pertinência que escolhemos aqui é o do produto acabado, aquele no qual se configura um texto portador de sentido como resultado de uma encenação que inclui os efeitos de sentido visados pela instância midiática e aqueles, possíveis, construídos pela pluralidade das leituras da instância de recepção numa relação de co-intencionalidade ${ }^{6}$.

Se relacionarmos todos esses elementos com os programas televisivos, poderemos dizer que a construção de sentido é o produto de um processo dinâmico, interdiscursivo; em outras palavras, os enunciados produzidos pelos participantes também dialogam com o lugar em que estão inseridos, com o direcionamento dado pelo programa e, principalmente, com o público (a audiência).

Nesse quadro, como na concepção de gêneros discursivos está implicado o lugar de construção de sentido, cabe-nos explanar melhor sobre a televisão. Esta pode ser entendida como uma indústria, em que interesses mercadológicos, sociais e políticos fazem parte do cotidiano de equipes, de empresas, de produtores envolvidos, direta ou indiretamente, na produção dos programas televisivos. O que é produzido nesse meio deve ser consumido. Como é uma ação complexa produzir um programa de televisão, pois é necessária a mobilização de vários elementos (renda, espaço físico, tecnologia etc), essa atividade torna-se reservada a uma minoria, em relação ao número de habitantes de um país, por exemplo. Dessa maneira, não há um contato direto entre produtor e consumidor, e sim uma "relação simbólica de contato” (Charaudeau, 2006a, p.223), em que o primeiro direciona o seu programa ao segundo, utilizando-se, como bases, estatísticas mercadológicas, opiniões públicas, definições de grupo.

Apesar desse aparente distanciamento, nesse suporte, cria-se um efeito de proximidade entre o telespectador e o programa, de tal modo que parece querer-se despertar a ilusão de uma interação face a face direta, principalmente quando algum participante do programa volta-se à câmera e dialoga com o público. Atualmente, essa busca de aproximação com o

\footnotetext{
${ }^{6}$ Grifos do autor.
} 
telespectador vem aumentando, tornando-se freqüente pedidos de participações por meio de ligações telefônicas ou por mensagens eletrônicas e fax. Apesar disso, o que ocorre é um efeito de contato, e não uma aproximação efetiva, pois as opiniões dos telespectadores também são inseridas na encenação midiática, tornando-se parte de uma representação.

Ainda de acordo com Charaudeau (2006a), um dos objetivos das mídias, e assim o da televisão, é a sobrevivência econômica, a lógica comercial. Esta faz com que os programas necessitem da publicidade e, em conseqüência disso, objetivem atrair o maior número de pessoas (audiência). A outra finalidade é informar o cidadão (o que foi intitulado lógica democrática), é possibilitar que acontecimentos políticos, sociais e outros interesses cheguem à população.

A lógica comercial e a democrática trazem alguns desafios no que se refere à construção de um programa midiático: inteligibilidade, visibilidade e espetacularização ${ }^{7}$. O primeiro desses desafios corresponde ao tratamento da notícia, à maneira como é efetivada a encenação verbal; a visibilidade tem o objetivo de tornar a notícia perceptível, visível; o último refere-se ao encaminhamento das encenações para que estas despertem interesses e, até mesmo, emoções.

Por tudo isso, o acontecimento, nos programas midiáticos, passa pelo processo de construção de sentido, em que um sujeito enunciador, com vistas a quem o seu discurso irá alcançar, faz uma captura perceptiva e interpretativa do fato, inserindo-o em um mundo comentado, nomeando-o. Nas mídias, isso se convencionou chamar notícia, sendo definida por Charaudeau (2006a, p.132) como: “um conjunto de informações que se relaciona num “espaço temático”, tendo um caráter de “novidade”, proveniente de uma determinada "fonte” e podendo ser diversamente tratado". 8

\footnotetext{
${ }^{7}$ Aquino (1997, p.103) já fazia menção à matiz de espetáculo que modela a linguagem televisiva.

${ }^{8}$ Grifos do autor.
} 
Dessa maneira, na mídia, todo acontecimento é construído. O evento em seu estado bruto é constituído em mundo relatado/comentado, ou até mesmo provocado, ganhando sentido por meio da língua e enveredando por caminhos diversos, dependendo do olhar do enunciador. Remetemos a este ponto o fato de que a instância enunciadora, sendo representada por vozes, tais como as de jornalistas e as de apresentadores, por meio do discurso e dos recursos extralingüísticos disponíveis, constrói relatos/comentários através da relação percepção-mundo-conhecimento, tendo em vista com quem irá interagir.

O seguinte esquema, elaborado por Charaudeau (2006, p.42), ilustra o processo efetivado na construção do acontecimento na mídia:

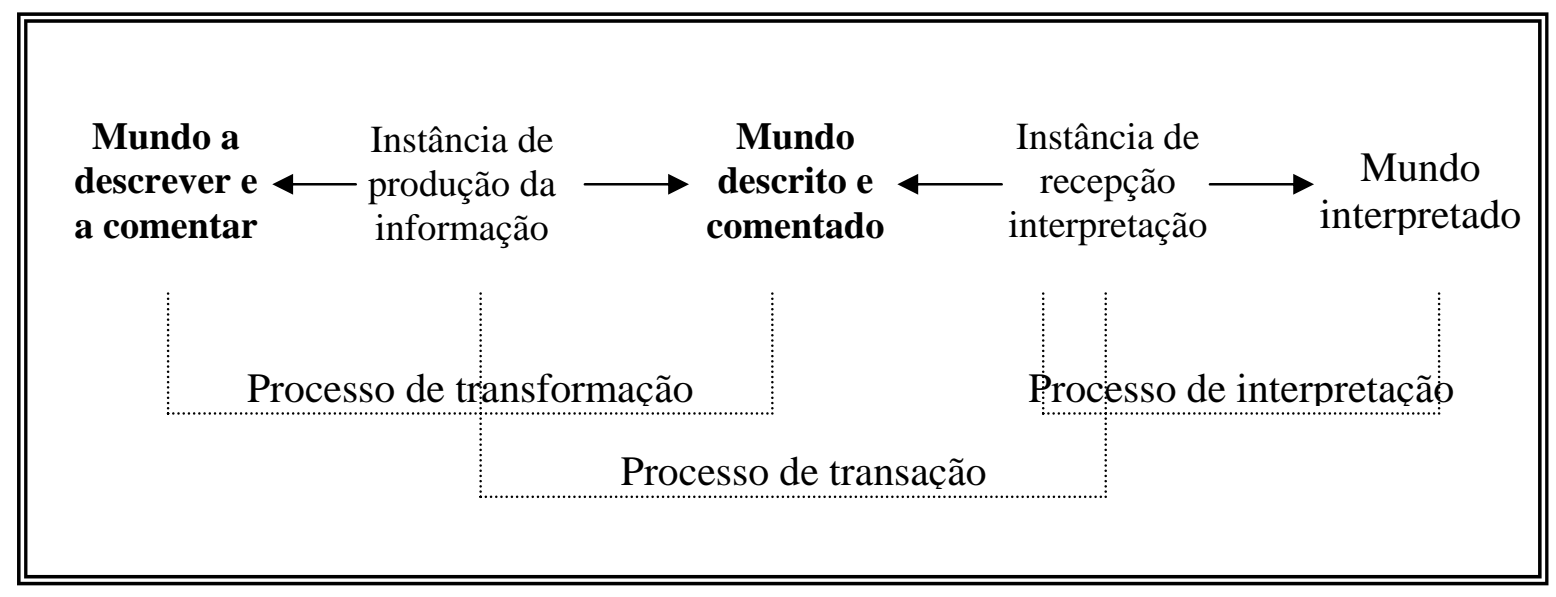

Quadro 03. Processo da construção do acontecimento na mídia.

Em geral, o acontecimento relatado e/ou comentado seria um primeiro contato com o mundo não-imediato, que produz efeito de verdade, de atualidade e de momentaneidade. Na mídia, apesar de serem representados esses efeitos, não há, por exemplo, um relato concluído, pois o tempo, por vezes, é curto para uma cronologia dos fatos.

Além do mais, na maior parte das vezes, o tempo de transmissão não coincide com o tempo do acontecimento, por uma questão de programação. Isso pode-se inverter, quando a transmissão é ao vivo, possibilitando que o efeito de momentaneidade, entre outros, se 
fortaleça. Porém, mesmo nesses casos, há câmeras que interferem na espontaneidade dos acontecimentos e das ações dos participantes.

Em relação ao interactante, ou à audiência, pode-se dizer que este, por sua vez, ao entrar em contato com os relatos e comentários, tenderá a interpretar as informações de acordo com seus conhecimentos de língua, de mundo, com o entorno sócio-históricoideológico. Para Charaudeau (2006a, p.94):

[...] Aquilo de que se fala, na notícia de um desastre de avião, difere de acordo com as pessoas que recebem essa notícia e as circunstâncias nas quais a recebem. Para uma será a causa (acidental ou criminal), para outras serão as conseqüências (individuais ou políticas), para outras ainda serão os detalhes do acidente (mórbidos ou técnicos). Assim, definiremos essa noção como ligada a de "universo de discurso", a qual se refere ao aspecto referencial da linguagem, isto é, ao movimento da linguagem que, ao mesmo tempo, em que está relacionado a um ato de troca, volta-se para o mundo para recortá-lo de uma maneira mais ou menos racional através das representações linguageiras e reconstruí-lo em categorias de sentido. ${ }^{9}$

Charaudeau (2006a) afirma que, ao referir-se ao mundo, por meio da atividade discursiva, o sujeito está posicionando um olhar, fazendo um recorte. O ponto evidenciado sobre determinado evento e a maneira como isso é efetivado no enunciado devem-se, por diversas vezes, ao objetivo da situação de troca. Assim, a instância midiática, quando enuncia e interpreta, utiliza-se das várias possibilidades de linguagens, tanto a verbal, quanto as nãoverbais, para orientar o sentido. Como também, quem interage com a notícia estará apto a fazer recortes, construir sentido e formar opinião a respeito da informação apresentada.

Sobre isso, devemos ressaltar que a maneira como a mídia informa sobre determinados acontecimentos, e direciona sentido, pode influenciar e conduzir opiniões de milhares de telespectadores, como afirma Aquino (1997, p.104):

Não se pode esquecer que a TV forma opinião ou a reforça - este é o seu poder; ela exerce controle. A grande massa brasileira não lê; informa-se pela

\footnotetext{
${ }^{9}$ Grifos do autor.
} 
televisão e isso constitui uma grande responsabilidade para esse organismo controlador de poder.

Dessa maneira, nas situações interativas produzidas pela mídia, instaura-se um jogo de vozes. Isso se refere à relação triangular presente nessas práticas sociais, em que a posição assumida pela instância midiática orienta e dialoga com os discursos dos participantes da interação, incluindo também “a terceira parte” (Perelman e Olbrechts-Tyteca, 1958, 2002), ou seja, aqueles para quem os programas são direcionados.

Os pontos de vista dos programas podem ser observados na maneira com que estes são organizados e, mais explicitamente, nas inserções de entrevistas, de proclamações públicas e de charges utilizadas durante a exibição, elementos que contribuem para criar os efeitos de verdade, como ocorre, em alguns momentos, no debate do programa Roda Viva, corpus deste trabalho. Destacamos, entre essas inserções, a charge criada pelo desenhista Paulo Caruzo para satirizar a situação política apresentada como um mar de lama (figura 3, página 33) pela organizadora do debate:

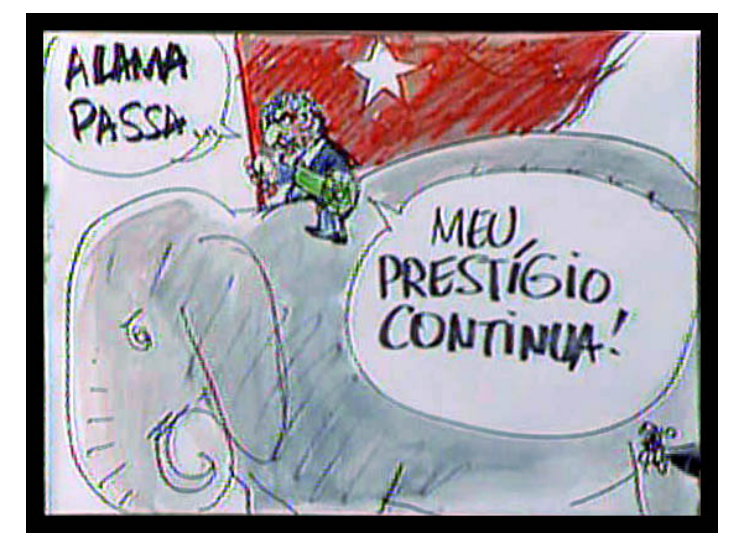

Fig.04. Charge a respeito da situação política.

Na figura 04, podemos constatar direcionamento de sentido a respeito das situações políticas debatidas durante a exibição do debate. Apesar do tom de brincadeira próprio do gênero charge, o desenho e o texto criados por Paulo Caruzo e focalizados pela câmera do 
programa apontam para uma crítica que revela o ponto de vista da instância enunciadora. Ao dizer que “A lama passa”, "Meu prestígio continua”, o desenhista faz menção ao conceito “mar de lama” (figura 03, página 33) apresentado pelo programa, e apresenta uma possível posição do presidente Lula a respeito da corrupção. Esse exemplo corrobora a afirmação de Charaudeau (2006a, p.131):

Não há captura da realidade empírica que não passe pelo filtro de um ponto de vista particular, o qual constrói um objeto particular que é dado como um fragmento do real. Sempre que tentamos dar conta da realidade empírica, estamos às voltas com um real construído, e não com a própria realidade.

À perspectiva apontada, salientamos que cada suporte midiático apresenta suas especificações, como no caso da televisão e seus recursos visuais e sonoros. Assim, observar programas televisivos é ter em vista as várias linguagens que se inter-relacionam para produzir sentido. Nesse suporte, imagens ancoram-se ao material lingüístico, sendo que todos esses elementos são direcionados por um olhar: a presença da câmera.

Charaudeau (2006a, p. 231) ainda ressalta que os gêneros sofrem mudanças no decorrer do tempo; os veiculados pela televisão não escapam disso, de maneira evidente ou discreta. Se antes os programas televisivos apresentavam características específicas de determinados gêneros (debate, entrevista etc), agora possibilitam um contínuo entre elas. Isso é possível observar nos debates televisivos que, atualmente, apresentam em seu formato inserções de micro-reportagens.

Sobre esse ponto, ressaltamos que os atuais gêneros televisivos caracterizam-se pela hibridização (Marcuschi, 2002b ${ }^{10}$; Charaudeau, 2006a). Isso se deve a fatores como o avanço tecnológico, as tendências mercadológicas, os “modismos” e os objetivos das mídias (comercial e democrático), como indicamos à página 35 deste trabalho.

\footnotetext{
${ }^{10}$ Em seus estudos sobre gêneros discursivos, Marcuschi (2002b) denomina intertextualidade inter-gêneros (um gênero com a função do outro) e heterogeneidade tipológica (um gênero com a presença de vários tipos).
} 
De maneira geral, as características dos programas midiáticos apresentadas nesta etapa do trabalho também fazem parte da formatação dos debates televisivos; entretanto, esses incluem peculiaridades que serão discutidas a seguir.

\section{$1.2 O$ gênero debate televisivo}

Charaudeau (2006a) sugere denominar gêneros do discurso da informação midiática às práticas discursivas que ocorrem na mídia, como é o caso do debate televisivo. Este se caracteriza pela presença de um mediador e, no mínimo, de dois participantes que comentam sobre um determinado tópico discursivo. Geralmente, as pessoas convidadas a participar têm algum tipo de relação com o tópico, ou por serem conhecedoras do mesmo, ou por terem certa autoridade para explanar sobre o assunto, ou mesmo por serem representantes de um determinado grupo.

Ainda de acordo com esse estudioso, na maioria das vezes, o posicionamento de cada participante é antagônico. Por esse motivo, essas interações estão propensas a momentos de conflito e de polêmica, em maior ou menor grau, conforme as ações e as reações dos debatedores.

Apesar de o debate ser um momento de deliberação, de troca linguageira entre sujeitos sociais, devemos estar atentos para o fato de que a mídia, como transmissora e organizadora do programa, organiza a situação interativa de modo a proporcionar um confronto de idéias e a provocar um novo acontecimento. Nas palavras de Charaudeau (2006a, p. 188-189):

Esse surgimento e esse confronto não são espontâneos ou ao sabor do debate social que se instaura no espaço público. Trata-se, ao contrário, de uma encenação organizada de tal maneira que os confrontos de falas tornam-se, por si, um acontecimento notável (saliente).

Dessa maneira, além de relatar ou comentar um acontecimento, a mídia pode provocálo. Isso se deve à encenação organizada dos programas, como afirma Charaudeau (2006a); já 
que cabe aos produtores escolherem quem serão os participantes, sobre qual assunto irão explanar, quais questões serão colocadas em pauta e como irão direcionar a situação.

Muitas vezes, a apresentação de certas perguntas já indica uma estratégia que possibilita o direcionamento da interação, ou seja, é possível que o mediador, ao perguntar e pedir informação, aponte características dos participantes que podem levar à (des)qualificação de suas imagens, conforme afirma Aquino (1997, p. 91):

As perguntas passam a se constituírem, muitas vezes, em estratégias cujos efeitos são cumulativos; além de um pedido de informação, esclarecimento, o entrevistador consegue, muitas vezes, mostrar, reforçar a face negativa ou positiva do entrevistado.

Além disso, a escolha de convidados com pontos de vista distintos e a opção por determinados temas polêmicos e atuais são elementos indicativos de utilização de uma estratégia de direcionamento do programa de maneira a provocar situações de confrontos.

Tais fatores, juntamente com o desempenho do mediador, que tanto pode tecer comentários, quanto provocar uma polêmica ou, ainda, determinar pausas e interferências, estabelecerão a extensão e o campo de ação do debate (cultural, científico, político, entre outros), e influenciarão a situação interativo-discursiva.

Apontamos, ainda, outras especificidades do gênero debate televisivo. Destacamos que, nessas práticas discursivas, os debatedores estão numa situação face a face direta. Por esse motivo, apesar de haver acordos pré-estabelecidos, os enunciados são constituídos durante a interação, de acordo com a ação e a reação de cada participante, o que torna a produção discursiva uma atividade interpessoal, dinâmica e única.

Em outras palavras, os discursos são adaptados durante a atividade enunciativa, conforme o encaminhamento dado pelos participantes. No decorrer desse processo interacional, os falantes, unidos em torno de um contexto espaço-temporal e sócio-histórico- 
ideológico, fazem escolhas lingüísticas que refletem tanto essa configuração contextual, quanto as posições sociais assumidas por eles.

Por esse último, frisamos que o objetivo da situação, aliado aos papéis institucionalizados dos debatedores, além de definirem o campo de ação do encontro, também delineará o grau de conflitos de idéias e de confrontos ideológicos do debate. Por essa razão, ressaltamos que os debates políticos trazem em sua configuração alguns traços específicos constituintes de um amplo jogo discursivo. Tais características serão discutidas a seguir.

\subsubsection{O discurso (de) político em situações de debate na televisão}

Como vimos, estudar a língua como prática social é também observar as condições de produção em que essa atividade é constituída; é considerar que, nas interações, os sujeitos elaboram seus discursos de acordo com a intencionalidade da situação discursiva. Também mencionamos que há nos programas de televisão, inclusive nos debates, características peculiares que englobam desde a produção desses encontros até as múltiplas finalidades (comerciais e sociais) pelas quais esses são veiculados. O que nos interessa frisar, quando explanamos sobre essas peculiaridades, é que essas influenciam o desenvolvimento da interação, especialmente o encaminhamento de sentido efetivado discursivamente. No caso de debates em que participam políticos, a questão não é diferente.

Ao tratarmos do discurso político, entendemos que já o termo "político” faz com que a palavra "discurso" resulte num sentido delimitado, ou seja, esse discurso é elaborado por sujeitos que cumprem papéis específicos no campo da política, inseridos em determinadas situações de interação que comportam objetivos particulares.

Há amplas vertentes derivadas tanto de estudos no campo das ciências sociais, quanto de investigações a respeito dos discursos políticos. Segundo Chilton (2004), há uma visão micro e uma macro, conforme a situação social e os fins, ambas relacionadas às questões de 
luta de poder ou, até mesmo, às cooperações oriundas de interesses comuns entre sujeitos ou grupos sociais.

Ainda de acordo com esse estudioso, no sentido micro "há conflitos de interesse, lutas de posição dominante e esforços de cooperação entre indivíduos, entre sexos e entre grupos sociais de vários tipos ${ }^{11 ”}$ (2004, p.03). Nesses casos, o que está em jogo corresponde às práticas estabelecidas, ou reforçadas, pelas próprias instituições sociais, como os direitos e os deveres dos cidadãos (liberdade, igualdade etc) ou como os múltiplos interesses que envolvem as relações sociais (dinheiro, por exemplo).

O conceito "macro", em que se inclui o nosso estudo a respeito dos discursos políticos, corresponde às ações relacionadas às instituições políticas do Estado, ou seja, aos conflitos de interesses entre aqueles sujeitos que almejam manter seu poder e aqueles que tentam resistir a ele, ou tomá-lo. Esse ponto de vista está diretamente relacionado a um poder dominante, ou “macro”, de um indivíduo (político) ou um grupo (partido e filiações) sobre uma sociedade.

Apesar de toda essa complexidade do conceito, podemos afirmar que o discurso cumpre importante papel no mundo da atividade política, como aponta Chilton (2004, p.06):

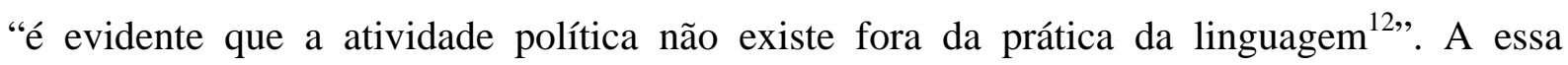
afirmação incluímos que é pelo discurso que podemos constituir espaços de deliberação e discussão política e, ainda, é pela elaboração de enunciados que é possível chegar ao convencimento e à persuasão, ambos extremamente almejados no campo da política, já que cabe a uma decisão coletiva, da população de um país, a escolha de manter ou mudar seus representantes, por meio de votos, nas eleições.

\footnotetext{
${ }^{11}$ At the micro level there are conflicts of interest, struggles for dominance and efforts at co-operation between individuals, between genders, and between social groups of various kinds.

${ }^{12}$ Whats is clear is that political activity does not exist without the use of language.
} 
Dessa maneira, os políticos devem ora prestar contas à comunidade de seus atos praticados, ora apresentar suas propostas, seus meios e suas finalidades. Por vezes, esses textos são pré-elaborados e proferidos (lidos) por algum político; em outros momentos, em interações face a face, os discursos são desenvolvidos durante a atividade interacional, instaurando-se um jogo imediato e dinâmico entre os participantes. No último caso, são organizados espaços para discussão, entre estes, alguns intermediados pela mídia, como os debates televisivos.

Aquino (2005) afirma que devemos atentar para a diferença entre analisar o discurso político, aquele previamente elaborado, institucionalizado, como comícios e declarações públicas, e o discurso de políticos, como os desenvolvidos em entrevistas e/ou debates. Essa diferença refere-se às características específicas das modalidades escrita ou falada e ao próprio meio utilizado para veicular o discurso.

A partir do que se expõe, é importante ressaltar que assumimos, neste trabalho, a expressão “discurso (de) políticos”, por selecionarmos como objeto de nossa investigação os discursos desenvolvidos por políticos que discutem a respeito de política, em situação de debate na televisão.

Outro ponto importante a mencionar refere-se aos discursos que constituem sentido político. Estes não são voltados, necessariamente, a um objetivo do campo da política, nem são enunciados constituídos por políticos; são discursos formadores de conceitos e idéias que circulam socialmente e podem ser encontrados em diversas situações de interação: em reuniões entre amigos e familiares, em programas jornalísticos etc. São aqueles que Charaudeau (2006b, p.40) intitulou “comentários”.

Falar a respeito de política, ou de ações de alguns políticos, é prática freqüente em nosso cotidiano. Esses “comentários” transpassam grupos, constituem opiniões, transformamse, criam efeitos de verdade e, principalmente, perdem sua origem, chegando até mesmo a ser 
utilizados em enunciados desenvolvidos no campo da política. Por todos esses elementos, esses discursos - não voltados, a princípio, para fins políticos - tornam-se forte fator de influência sobre a sociedade.

Em outras palavras, os discursos produzidos pela população constroem idéias, conceitos e imagens referentes ao campo político e podem, dessa maneira, colaborar para a interpretação ou para a construção da opinião pública, no momento em que esta interage com os debates políticos televisivos.

Quanto a esse último, por se tratar de um gênero polêmico, provocado pela mídia ao escolher participantes com posicionamento partidário oposto, abrange fatores culturais, históricos, ideológicos registrados lingüisticamente nos enunciados produzidos pelos políticos. Estes, por se encontrarem em um contexto resultante de contrastes ideológicos e controvérsias discursivas, elaboram discursos que podem orientar conclusões que desqualificam fatos, pessoas e situações relacionadas ao(s) seu(s) adversário(s). Ao contrário do que ocorre nos textos escritos em que, apesar de estabelecerem um diálogo entre o "eu" enunciador e o “outro” leitor, isso acontece de modo não imediato, nos debates, as trocas são constantes, possibilitando reajustes nas falas. Assim, nesse campo de ação comum, por muitas vezes, há a presença de vozes procurando negar ou até mesmo derrotar a(s) outra (s).

Dessa maneira, utilizar-se de discursos desqualificantes pode resultar na exaltação da própria imagem ou do ponto de vista assumido, objetivo muito almejado nos debates entre políticos, o que transforma o encontro em uma "luta discursiva” (Charaudeau, 2006b, p.23), isto é, nessas interações, o campo discursivo é dominante, e por meio dele, os sujeitos procurarão apresentar legitimidade, justificada em nome de valores, e conquistar credibilidade.

Todos esses elementos são constitutivos da situação de interação dos debates políticos televisivos. Como vimos, o próprio encontro propõe uma disputa, principalmente se 
pensarmos que as posições dos participantes permitem que cada um direcione um olhar específico a determinados fatos ou assuntos. Além disso, há valores, crenças, posições ideológicas e, principalmente, relações de força, próprias desse jogo, que agem sobre a situação discursiva, pois estão presentes nos processos cognitivos e são registradas no discurso, por meio de pistas lingüísticas.

\subsection{A posição ideológica e o jogo discursivo}

Ao centrarmos o campo de observação nos discursos de políticos em debates televisivos, observamos que, nesses encontros, geralmente, ou na maioria das vezes, os participantes tendem a não compartilhar das mesmas opiniões, o que cria um espaço de disputas de idéias ou de confrontos de posições ideológicas assumidas. De fato, como toda atividade discursiva subjaz uma ideologia (Koch, 1996; Guimarães, 1999), não mencioná-la nos estudos a respeito de debates políticos, é deixar de observar importantes elementos que estão presentes nessas práticas e que influenciam, de certa maneira, os discursos produzidos por esses sujeitos sociais.

Sabemos que cada um de nós possui uma história particular e outra coletiva, ambas relacionadas. Isso implica o quanto conhecemos sobre o mundo e sobre nossa língua. Portanto, constituímos crenças, hierarquizamos valores, aprendemos a nos posicionar ideologicamente por meio de nossas vivências. Nesse quadro, as visões de mundo não existem desvinculadas da linguagem, entendida no seu sentido amplo, que comporta a verbal e as nãoverbais. Dessa maneira, os sujeitos compreendem e atribuem valores ao mundo também, e principalmente, por meio do discurso, designando-o, problematizando e construindo um posicionamento em relação a ele. Isto quer dizer que a posição que assumimos socialmente já é um recorte de percepção da realidade e nos permite afirmar que não há visão única sobre os 
fatos observáveis do mundo, pois esse olhar dependerá de fatores históricos, culturais, ideológicos, como também, conhecimentos, crenças e valores.

É de nosso conhecimento a existência de uma vasta literatura sobre ideologia: desde o século XIX, na França, com o filósofo Antoine Destutt de Tracy, em 1801, que a tratou como ciência das idéias, passando por Napoleão Bonaparte, em que o termo ganhou sentido pejorativo e chegando ao Marxismo, em meados do século XIX, enveredando seus estudos para o campo social e, consecutivamente, para as relações de dominação.

Essa última concepção de ideologia perpassou os enlaces dos séculos XX e XXI. Atualmente, muitos são os estudiosos que abordam esse tema, considerando, como base, a concepção marxista. Outros partem desta visão, porém, enveredam suas pesquisas por outros campos, tal como a dimensão ideológica do discurso. Lembremos de Bakhtin (1929) que já mencionava a relação língua e ideologia, afirmando que, ao utilizarmos a língua, estamos assumindo uma postura ideológica.

Partimos dessa última visão para assumir o conceito de ideologia como é entendido por Van Dijk (2003), no quadro da Análise Crítica do Discurso, que a concebe como um fenômeno de cognição social. Para ele, as ideologias afetam as estruturas mentais, intervindo na produção discursiva. Isso é ativado nas práticas sociais e nas relações entre grupos.

O autor observa a ideologia de maneira multidisciplinar, abordando temas que englobam discurso, cognição e sociedade. Van Dijk (2003, 2004, 2005) aponta que as ideologias são as bases das atitudes sociais. Para esse estudioso, muitas de nossas idéias ideológicas foram assimiladas, primeiramente, no contexto familiar; também as constituímos em outras interações sociais, assistindo à televisão, lendo revistas, jornais ou livros escolares, conversando com amigos, entre outros. 
Em relação às práticas discursivas, as ideologias estruturam desde a organização do discurso até as escolhas lexicais pelas quais optamos ao designar o mundo. Além disso, a interpretação também é inserida num quadro ideológico, pois, como mencionamos, essas idéias e crenças estão diretamente ligadas aos conhecimentos armazenados em nossa memória e que são ativados, paralelamente, nas ações linguageiras. Assim, quando um sujeito opta por determinada palavra para designar um objeto, ele estará opinando acerca dele, de acordo com sua opinião ideológica.

Por todos esses elementos, consideramos também nas análises discursivas e, assim, interacionais e sociais, os elementos cognitivos implicados nos discursos dos falantes, que constituem, no palco das interações, relações de autoridade e poder. Dentro desse quadro, os participantes constroem discursos e fazem interpretações de acordo com seu papel institucionalizado, sua posição ideológica e seus conhecimentos sobre as regras e os acordos da situação de interação.

Ainda de acordo com Van Dijk (2003, 2004, 2005), observamos que o discurso abrange uma dimensão ideológica perceptível pelas marcas deixadas nos enunciados. Nestes, a ideologia pode aparecer de maneira explícita, por exemplo, pela escolha de certas nomeações, ou implícita, por meio de entonação enfática (na modalidade falada) etc. Apenas para ilustrarmos este último caso, tomemos o turno de José Eduardo Cardozo (J.E.C.) no debate transcrito em anexo, às linhas 1007-1009:

J.E.C. [...] a a memória se apaga não existiu o Collor no Brasil não existiu o o escândalo do governo Fernando Henrique Cardo::so não não o no governo do PFL nunca houve NAda... houve apenas aGOra... ou seja a corrupção nasceu com o PT senador será isso?

Para contestar a opinião de César Borges, do PFL, José Eduardo Cardozo (J.E.C.) desenvolve um discurso que apresenta a corrupção como ação ilícita praticada também em 
outros governos. Para tanto, o enunciador além de indicar nomes de personalidades políticas envolvidas em denúncias, também seleciona a expressão "no governo do PFL nunca houve NAda... houve apenas aGOra” (linha 1008), utilizando-se de entonação enfática, reforçando seu ponto de vista.

Sobre isso, nosso conhecimento do contexto situacional/histórico permite-nos depreender tom irônico no procedimento lingüístico e extralingüístico de José Eduardo Cardozo (J.E.C.) utilizado para demarcar uma posição ideológica. Em outras palavras, o enunciador inclui em seu discurso o ponto de vista de seu adversário de maneira a ironizá-lo.

As marcas ideológicas podem também aparecer nos assuntos discutidos (tópicos $\operatorname{discursivos}^{13}$ ). Quanto a estes, podemos salientar que eles organizam, em categorias, os fatos observáveis no mundo, principalmente na maneira como são referidos, nas seleções lingüísticas, como ocorre com alguns títulos. Ainda, as idéias utilizadas como tópicos estão diretamente ligadas aos fatores sociais, pois são discutidas aquelas presentes na sociedade. No campo da política, liberdade, democracia, ética e moral são assuntos freqüentes nas atividades discursivas de políticos, podendo enveredar por diferentes sentidos conforme a maneira de pensar o mundo desses falantes.

É possível que esses tópicos ganhem concepções distintas, na maneira como são referidos no discurso, nas escolhas lexicais que revelam universos ideológicos e que exprimem valores ora positivos, ora negativos.

Por mais que levemos em consideração a interferência das ideologias na produção discursiva, devemos salientar que, por vezes, um enunciador pode ocultar sua verdadeira visão de mundo e construir um discurso que resulte numa outra ideologia.

\footnotetext{
${ }^{13}$ Terminologia da Análise da Conversação.
} 


\subsubsection{A situação discursiva entre grupos (de) políticos}

Outro ponto a salientar refere-se à possibilidade de falarmos como integrantes de certos grupos sociais, tal como ocorre com os políticos, ao representarem um partido. Nessas ocasiões, há um posicionamento, por meio do discurso, de maneira ideológica. Assim, é possível falar em ideologias de grupo, representações sociais constituintes de identidades. Na visão de Van Dijk (2003), os esquemas específicos de grupo são organizados por um número de categorias que representam a posição assumida de seus membros, tais como a aparência, as atividades, os objetivos, as normas, as relações com outros grupos, entre outros.

Ainda de acordo com o autor, os esquemas de grupos implicam fatores que permeiam os processos cognitivos e se refletem nos discursos. O estudioso afirma que há algumas “perguntas” armazenadas em nosso sistema cognitivo que estão relacionadas a uma identidade de grupo e às ideologias. A saber:

1. Pertinência: quem nós somos? Quem pertence ao nosso grupo? Quem nós podemos admitir?

2. Atividades: o que temos feito? O que esperam de nós?

3. Objetivos: por que fazemos isto? O que almejamos?

4. Normas: o que é bom ou mau? O que é permitido ou não?

5. Relações: quem é amigo ou inimigo? Qual lugar nós ocupamos na sociedade?

6. Recursos: o que temos que os demais não têm?

7. O que temos que os demais também têm?

Os esquemas apontados tornam-se evidentes quando dois ou mais grupos apresentam interesses opostos ou, mais precisamente, quando há uma "luta social em uma determinada situação de dominação” (Van Dijk, 2003, p. 63). O autor assinala que a oposição ideológica entre grupos manifesta-se nos planos cognitivo e discursivo, por meio de várias formas de polarização. 
Sobre esse ponto, em algumas situações de interação, principalmente nos debates políticos televisivos, é perceptível a elaboração de enunciados que ora enaltecem as características positivas de quem fala, ou de seu grupo, ora evidenciam recortes negativos do seu (s) opositor (s). Selecionamos, entre as ocorrências de nosso corpus, os turnos de José Eduardo Cardozo (PT) e de César Borges (PFL), que selecionam elementos lingüísticos indicativos de uma oposição ideológica entre grupos (às linhas 1061-1072):

J.E.C. só uma parte... breve apeSAR disso... eu acho que não pode haver esse ( ) senador César Borges... há gente boa e gente má em todos os partidos infelizmente... porque os partidos são formados por pessoas... e que se submetem às tentações ou resistem a elas... agora

C.B.

mas também só havia gente boa do PT

Durante o debate (corpus deste trabalho), os grupos políticos (oposição e governo) apresentaram suas opiniões a respeito da corrupção no espaço político e das denúncias que envolviam membros do Partido dos Trabalhadores (PT), na época em que o programa foi organizado. Se por um lado, os políticos da oposição enfatizaram a necessidade de investigar e de punir os petistas culpados, e apresentaram acusações ao PT por conta de algumas ações ilícitas; por outro, o grupo do governo defendeu a tese de que também havia corrupção em outros governos e partidos e, por isso, a solução seria uma reforma política.

Essa última posição está registrada no discurso de José Eduardo Cardozo (J.E.C.) por meio de formulações lingüísticas indicativas da idéia de que em todos os partidos políticos há corrupção, como: “há gente boa e gente má em todos os partidos” (linha 1063). Durante seu turno, César Borges, do PFL, seleciona ironicamente a expressão "só havia gente boa do PT" (linha 1066).

Observamos, nesse exemplo, que o político do governo procede à defesa de seu grupo, enquanto seu adversário apresenta desqualificação por meio de um discurso que, por ser 
elaborado dentro de um contexto, possibilita-nos depreender um sentido contrário do que foi dito sobre os políticos petistas, ou seja, “não havia somente gente boa do PT”. Dessa maneira, ambos procedimentos são indicativos de uma disputa ideológica.

Todos esses elementos nos permitem afirmar que, em algumas práticas discursivas, há uma auto-apresentação positiva em contraste com uma negativa com referência ao (s) adversário (s). Isso pode-se dar por meio de quatro princípios, de acordo com Van Dijk (2003):

1. Dar ênfase as nossas características positivas.

2. Dar ênfase às características negativas do outro.

3. Esconder nossas características negativas.

4. Esconder as características positivas do outro.

Em geral, essas ações discursivas dão sentido ao mundo a partir de pontos de vista de determinados grupos. Nos enunciados de políticos, geralmente, estabelece-se uma oposição. Há uma relação entre o “eu”, a voz de um grupo, e o “outro”. Isso é compreendido pela relação que o discurso mantém com a ideologia, pois, enquanto a primeira determina o uso do segundo, este, por sua vez, influencia a maneira de apreender, de expressar e, até mesmo, de modificar as ideologias que permeiam os sistemas cognitivos dos sujeitos.

Se o discurso reflete as posições ideológicas e é determinado por elas, podemos afirmar que os enunciados se transformam em estratégias que podem ser utilizadas para o convencimento e a persuasão, isto é, os sujeitos organizam seus textos de maneira a escolher determinados elementos lingüísticos disponíveis para construir seus discursos e conseguir a adesão do(s) outro(s) interactante(s), em relação ao seu ponto de vista. Isso nos permite dizer que as ações discursivas são providas de intencionalidade e, assim, especificam-se pela argumentatividade - assunto que será tratado no próximo capítulo. 


\section{CAPÍTULO II}

A dimensão argumentativa do discurso (de) político 
[...] Assim, para retomarmos o exemplo familiar do homem político, este justifica a sua ação, na altura da campanha para sua reeleição, retendo unicamente as medidas e os resultados favoráveis. O seu adversário, de uma maneira não menos seletiva, encarrega-se dos malogros e das insuficiências.

Pierre Oléron

\subsection{A argumentação como atividade discursiva, interativa e criativa}

Ao falarmos, agimos sobre as pessoas e sobre o mundo. Nas relações sociais, os sujeitos, por intermédio da língua, criam e partilham juízos de valor, avaliando e julgando o mundo empírico. Ao mesmo tempo, eles almejam influir no comportamento do outro, fazendo com que este compartilhe de suas opiniões (Koch, 1996; Guimarães, 1999).

Por todos esse elementos, é possível afirmar que a argumentatividade é inerente à língua (Guimarães, 1999) e esta, por sua vez, como sistema e como instrumento do discurso, realiza-se nas relações interativas. Assim, examinar a língua em uso é pensá-la dialogando com fatores sociais e históricos. E ainda, é pensar o homem como ser social capaz de agir e de reagir discursivamente.

Nesse quadro social-interativo, todo discurso inclui outros discursos, de maneira a aceitá-los, negá-los ou, mesmo, ironizá-los. Dessa maneira, as práticas discursivas tornam-se momentos de trocas, e o discurso constitui-se como dialógico e dinâmico.

Também nessa perspectiva, é possível dizer que o ato de argumentar insere-se em um quadro interativo. Enquanto um sujeito argumenta, o outro tenderá, por vezes, a contraargumentar. Isso pode-se dar, em conformidade com a situação, em maior ou em menor grau, isto é, há interações que propiciam o jogo argumentativo, podendo resultar em polêmica ou, até mesmo, em acordo, “ainda que seja acordado o fato de que é impossível chegar a um acordo” (Aquino, 1997, p.127), como é possível ocorrer em debates entre políticos. 
Quando falamos em interação, definimo-la como sendo a co-presença entre dois ou mais sujeitos, que constroem, concomitantemente, um diálogo espontâneo ou previamente determinado, envolvidos em fatores cognitivos, sociais, culturais e históricos. Podemos afirmar que cada interação é única, por se constituir de acordo com as características dos interactantes, juntamente com seus papéis institucionalizados, as condições de produção e as estratégias utilizadas para determinados fins. De acordo com Fávero, Andrade e Aquino, (1998, p. 93):

[...] a interação caracteriza-se por situar-se em um contexto em cujo âmbito se estabelece um campo de ação comum no qual os sujeitos envolvidos podem entrar em contato entre si. Torna-se, portanto, fundamental a capacidade de ação de cada indivíduo, que deve estar apto a influir no desenvolvimento sucessivo da interação, determinando-o com sua atuação: cada ação de um sujeito deve constituir uma premissa das ações realizadas posteriormente pelos demais.

Assim, os participantes, em situação interativa, agem e reagem entre si. Os discursos possibilitam uma transformação nos contextos presentes, fazendo com que cada interactante saia diferente após uma interação.

Ainda, salientamos que, além da argumentatividade já fazer parte da organização interna da língua, as palavras são instrumentos do ato de argumentar. Sobre isso, os recursos disponíveis no repertório lingüístico são utilizados para dar sentido aos seus referentes de maneira a evidenciar recortes pelos quais comportam valores argumentativos.

Por tudo o que mencionamos até agora, torna-se evidente que a atividade discursiva/argumentativa também é determinada pela criatividade dos sujeitos que, ao elaborarem seus discursos, de maneira dinâmica, levam em conta o outro da interação e o seu projeto de dizer - como os políticos, em debates televisivos, consideram tanto o telespectador, quanto os seus adversários. Assim, nessa ação criativa e interativa está também implicada uma relação retórica e argumentativa. 


\subsection{A Retórica aristotélica e a retomada da argumentação no século XX}

A argumentação foi importante objeto de estudo da Retórica na Antigüidade. Apesar de seu esquecimento ${ }^{14}$, a Retórica ressurgiu, libertando-se do valor pejorativo e abordando novas perspectivas em direção aos estudos da argumentação, sendo denominada, por Perelman e Olbrechts-Tyteca $(1958,2002)$ - entre outros - Nova Retórica, baseada nos valores, na cooperação e no acordo entre os participantes.

Os estudos contemporâneos sobre a argumentação, em específico os de Perelman e Olbrechts-Tyteca (1958, 2002) mantêm alguns conceitos dos pensamentos clássicos da Retórica:
o a função prática da argumentação na sociedade;
o a relação argumentação/convencimento/persuasão;
o as opiniões partilhadas entre os participantes;
o a adequação a um público;
o os papéis sociais;
o a noção de verossimilhança.

Na sua concepção contemporânea, os estudos da argumentação retomam alguns preceitos de Aristóteles, principalmente no que se refere às noções de verdade e de verossimilhança. Seus estudos distanciam-se dos raciocínios lógicos formais, do pensamento cartesiano e assumem uma noção do razoável, do crível.

Nesse quadro, a argumentação é uma ação de alcançar ou intensificar, por meio do discurso, o assentimento do auditório. Perelman e Olbrechts-Tyteca $(1958,2002)$ apontam dois tipos de adesão: a persuasão, quando o orador está preocupado com o resultado, com a ação; e a convicção, ou convencimento, que se volta à racionalidade, às faculdades

\footnotetext{
${ }^{14}$ Os estudos de Aquino (1997), Guimarães (1999), entre outros, indicam o fato de que a Retórica, durante um longo período, distanciou-se das concepções aristotélicas, voltando-se, principalmente, às figuras de estilo, de ornamento, e incluindo-se exclusivamente às questões literárias.
} 
intelectuais. Isso não quer dizer que ambos agem de maneira totalmente independente um do outro, mas sim que eles estão ligados por uma relação estreita.

É importante salientar a respeito da enumeração das partes da argumentação observadas também na Antiguidade: exórdio, narração, prova, refutação, conclusão e epílogo. Entre elas, o exórdio, amplamente estudado por Aristóteles, Cícero e Quintiliano, foi apontado por Perelman e Olbrechts-Tyteca $(1958,2002)$ como importante momento em que a atitude lingüística visa atingir o auditório de maneira a aproximá-lo, ou seja, despertar sua atenção, seu interesse, já que segundo esses autores, "para que uma argumentação se desenvolva é preciso, de fato, que aqueles a quem ela se destina lhe prestem alguma atenção” (op. cit., p.20).

No exórdio, é possível que se apresentem elementos que irão influenciar a situação enunciativa e, assim, as escolhas argumentativas posteriores, tornando-se, por diversas vezes, um momento significativo para a argumentação, pois é na apresentação do discurso e na preparação do auditório que o orador poderá direcionar, o mais próximo possível, o sentido pretendido por seu enunciado.

Ainda de acordo com Perelman e Olbrechts-Tyteca (1958, 2002), o sujeito enunciador tenderá, ao elaborar seu exórdio, encaminhar seu discurso de maneira a construir uma imagem de competência, de honestidade, ou mesmo, de imparcialidade, imprimindo a si credibilidade e prestígio para explanar a respeito do assunto em questão.

Por todos esses elementos, o exórdio deverá ser elaborado de acordo com as condições de produção, com o(s) tópico(s) discursivo(s) abordado(s) e com a relação entre os participantes. Caso o orador leve em conta todos esses fatores, possivelmente construirá enunciados que ora exaltarão suas características positivas, para que estas fortaleçam seu ponto de vista e lhe dêem autoridade para argumentar, ora valorizarão as qualidades do 
auditório, “estimulando o amor-próprio deste, falando de suas capacidades, de seu bom senso, de sua boa vontade” (Perelman e Olbrechts-Tyteca, 1958, 2002, p. 562).

Nessa perspectiva, consideramos ser a situação interacional o lugar em que a habilidade argumentativa poderá construir um discurso convincente e persuasivo, o qual alcançará uma identificação com o auditório. Além disso, a condição de produção influencia a elaboração da argumentação, pois sabemos da existência de regras que estabelecem a organização de um diálogo, de um debate, entre outros, ou seja, existem acordos prévios resultantes das próprias normas da vida social.

Outro fator essencial à análise da argumentação refere-se à relação entre orador e auditório. O primeiro é o sujeito que, por meio do discurso, objetiva ganhar a adesão do segundo, que pode aceitar ou não a tese apresentada.

É importante frisar que o auditório nem sempre é o conjunto de pessoas presentes, numa interação. Também, não é necessariamente aquele a quem o orador dirige seu discurso de maneira direta. O auditório pode ser o que Perelman e Olbrechts-Tyteca $(1958,2002)$ denominou terceira parte, como, por exemplo, nos debates políticos televisivos, em que o telespectador é o sujeito a quem os discursos visam agir.

A Nova Retórica introduziu os conceitos sobre dois tipos de auditório: o universal e o particular. Ao primeiro, que parte sempre de um auditório heterogêneo, deve-se à aprovação unânime ou à argumentação provável de ser aceita por uma maioria. O segundo corresponde a grupos específicos caracterizados por assumirem valores e opiniões relativos a determinada cultura e ideologia. Sobre o último, Perelman e Olbrechts-Tyteca mencionam (1958, 2002, p.23) que:

[...] as opiniões de um homem dependem de seu meio social, de seu círculo, das pessoas que freqüenta e com quem convive: "Você quer", dizia M. Millioud, "que o homem inculto mude de opinião? Transplante-o". Cada meio poderia ser caracterizado por suas opiniões dominantes, por suas 
conviç̧ões indiscutidas, pelas premissas que acerta sem hesitar, tais concepções fazem parte de sua cultura e todo orador que quer persuadir um auditório particular tem de se adaptar a ele. Por isso a cultura própria de cada auditório transparece através dos discursos que lhe são destinados [...]

Os autores afirmam que o orador, com vistas à argumentação, deve levar em consideração toda a complexidade que envolve seu auditório, desde sua natureza social e cultural, até suas opiniões dominantes. O desprezo dessas condições cognitivas e sociais pode resultar em argumentos isentos de objeto e de sentido.

Todos esses elementos permitem-nos dizer, como já observaram Perelman e Olbrechts-Tyteca (1958, 2002), que não apenas a língua em comum possibilitará o acordo entre os interactantes, mas também a maneira de organizá-la e apresentá-la, isto é, a escolha de recursos lingüísticos e a elaboração de estratégias discursivas e argumentativas devem ser sempre ajustadas ao auditório em questão.

Vale ressaltar que o tipo de auditório é uma construção do próprio orador que, por meio de perfis psicológicos, sociais, culturais, prevê uma imagem daquele a quem ele quer conseguir uma adesão. Por esse motivo é que Perelman e Olbrechts-Tyteca $(1958,2002)$ ressaltam a importância de o orador conhecer com quem irá interagir, principalmente tomar conhecimento das funções sociais cumpridas por esse(s) sujeito(s), pois isso já revela possíveis posições.

Assim, a argumentação é, por inteiro, relativa ao auditório. É a adequação do discurso a quem o orador deseja influenciar que fará com que o auditório não seja o mesmo no final da interação; uma nova concepção da realidade ou do referente será conferida ao mesmo pelo orador.

Conforme a definição de auditório universal e particular, salientamos a existência de dois objetos de acordos. Ao primeiro vale-se o acordo baseado no real, e ao segundo, o ligado ao preferível. Nas palavras de Perelman e Olbrechts-Tyteca: 
[...] na argumentação, tudo o que se presume versar sobre o real se caracteriza por uma pretensão de validade para o auditório universal. Em contrapartida, o que versa sobre o preferível, o que nos determina as escolhas e não conforme uma realidade preexistente, será ligado a um ponto de vista determinado que só podemos identificar com o de um auditório particular. (Perelman e Olbrechts-Tyteca, 2002, p.74)

Em relação aos acordos baseados no real, temos os fatos, as verdades e as presunções. Primeiramente, explanaremos sobre a questão dos fatos e das verdades, pois, de maneira geral, ambos estão sempre ligados ao que é aceito pelo auditório.

Os fatos correspondem aos acordos comuns entre os participantes. Isso não quer dizer que o argumento tido como fato não seja suscetível de ser questionado, pois, principalmente em situações polêmicas, ele poderá deixar de ser reconhecido a partir de questionamentos por parte do (s) adversário (s).

Já as verdades assumem as mesmas características dos fatos, contudo, são mais abrangentes, inserem-se em programas mais complexos, como nos discursos científicos, filosóficos e religiosos; incluem-se, assim, aos sistemas de alcance geral.

Além dos fatos e das verdades, há a presunção que é ligada ao verossímil, ou, mais precisamente, ao que é dado como “normal” pelo auditório. De acordo com a intenção do orador, torna-se possível a tentativa de inverter a posição assumida pelo outro.

Sobre os argumentos baseados no preferível, ou seja, nos valores, em suas hierarquias e nos lugares comuns, Perelman e Olbrechts-Tyteca $(1985,2002)$ afirmam que eles estão mais ligados aos auditórios particulares.

Há no mundo um sistema de valores que, da maneira como são hierarquizados e classificados, caracterizam os grupos sociais. Estes construirão suas imagens, positiva ou negativamente, de acordo com os valores assumidos e com suas condutas em relação a eles. 
No campo político, alguns valores, tais como a lealdade, a ética e a honestidade, são vistos como unânimes e universais, chegando até mesmo a surtir efeitos de fato. Geralmente, podem ser utilizados com o intuito de motivar o auditório a certas escolhas, justificando-as como sendo indispensáveis.

Por todos esses elementos, os valores cumprem importante função na argumentação. Até mesmo é possível afirmar que eles se inserem como base de todo processo argumentativo, principalmente nos discursos jurídico, filosófico e político. Para tanto, mais uma vez torna-se necessário conhecer quais são os valores aceitos pelo auditório em questão. Ao tomar conhecimento, o orador poderá afirmá-los ou, mesmo, desqualificá-los, entretanto, dificilmente poderá negá-los.

No discurso, os valores são possíveis de serem percebidos pelas marcas lingüísticas, principalmente por palavras e por expressões que trazem, à presença do outro, certa carga de valor. Ainda, frisamos que eles fazem parte do processo de construção de sentidos, sendo este importante fator para a argumentação.

\subsection{A construção de sentido como importante processo da argumentação}

Como vimos, na argumentação, o orador visa obter o assentimento do auditório, e isso é efetivado no e pelo discurso. Portanto, cabe ao falante elaborar seus enunciados de maneira a direcionar, o mais próximo possível, sentidos conforme seu projeto de dizer, pois, é por esse viés que será possível chegar aos acordos propostos pela Nova Retórica.

Koch (2006a) afirma que o sentido não é algo preexistente à decodificação. Para a autora, ele consiste numa relação complexa de interpretação, em que a situação de discurso fornecerá subsídios para o preenchimento dos vazios existentes nos textos. Assim, é na enunciação, nas pistas lingüísticas e nas informações da situação de interação que efeitos de 
sentido são constituídos. Sobre isso, lembremos Charaudeau (2006a) que faz menção ao lugar da construção de sentidos, ponto já discutido em nosso primeiro capítulo.

Dessa maneira, podemos afirmar que o sentido é construído nas relações interativas e sociais. Charaudeau (2006a) também faz menção sobre isso, afirmando que o sentido é resultante de dois processos implicados na atividade discursiva: o da transformação e o da transação.

O primeiro consiste em significar o mundo, estruturando-o em categorias. Isso se dá pela ação de nomeá-lo que, consecutivamente, leva à (des)qualificação e ao julgamento, ambos imbricados na atividade de argumentar.

O segundo processo, denominado transação, está relacionado à presença do outro(s) participante(s), à relação dinâmica entre os interactantes. Esse processo está ligado ao conceito de auditório proposto pela Nova Retórica, em que o orador constrói uma imagem do outro, baseada nos papéis sociais, nos interesses e na situação instaurada no momento da interação; a partir de então, pelo discurso, ele dará sentido aos seus referentes. Em outras palavras, é falando para alguém, ainda que seja numa deliberação consigo mesmo, que o sujeito constrói uma imagem do mundo. Assim, o processo de transação sempre determinará o de transformação.

Entre esses dois processos, há ainda fatores imbricados na atividade de significar o mundo. São eles: nossos conhecimentos e nossas crenças.

No discurso, as categorias lingüísticas combinam-se, efetivando o sentido do objeto, isto é, ao nomear e categorizar, o orador o faz por meio de tentativas, que podem ora se modificar, ora se manter. Dessa maneira, o sujeito, ao posicionar um olhar sobre o mundo, estará incluindo-o em categorias de conhecimento. Ao mesmo tempo, voltado para si, tenderá a construir categorias de crença. 
Tanto o conhecimento, quanto a crença fazem parte da atividade discursiva e são determinantes na configuração do sistema de interpretação. Trata-se de uma relação estreita e recíproca e, por meio dela, os sujeitos criam sentidos discursivamente. Sobre a construção e armazenamento dos saberes de conhecimento, Charaudeau (2006a, p.44) afirma:

Pela aprendizagem que se desenvolve através das práticas da experiência, às quais se aplica uma observação na empiria do sentir, do ver e do ouvir, no jogo dos erros e dos acertos, na predição das percepções, e que permite ao sujeito depreender recorrências no interior desses fenômenos, e construir assim uma explicação empírica do mundo fenomenal. E pela aprendizagem dos dados científicos e técnicos que tentam explicar o mundo a partir do que não é visível com o auxílio de um instrumental intelectual (cálculo, raciocínio, discurso de explicação mais ou menos vulgarizado).

Todos esses elementos, adquiridos nas experiências humanas, são armazenados na memória do falante, formando seus conhecimentos. Evidentemente, eles são filtrados pelo entorno cultural e histórico de cada um. Em geral, é possível dizer que os conhecimentos determinam a “objetividade” do discurso.

A respeito dos saberes de crença, estes, paralelamente aos conhecimentos, possibilitam o processo de interpretação e de construção de sentidos, ao posicionar um olhar ligado a uma “subjetividade”.

De maneira geral, as crenças estão ligadas à ação de avaliar e de apreciar o mundo, o homem e as regras sociais. Elas apontam tanto para a avaliação dos comportamentos sociais, aceitos ou não em certas sociedades, quanto para a justificativa desses julgamentos.

É pelos saberes de crença que os sujeitos podem ora aderir, ora rejeitar determinadas situações e atitudes. Isso se deve à existência de categorias avaliativas, tais como: o bom e o mau, o belo e o feio, o eficaz e o ineficaz, o justo e o injusto, o herói e o vilão, entre outros.

Assim, na atividade discursiva, as crenças e os conhecimentos de mundo resultam em um duplo processo para a construção de sentido, e é por meio deles que a argumentação se efetiva. 
Ainda, salientamos que, no campo político, os discursos tendem a orientar certas categorias de crenças, levando em conta o que é aceito ou não pela sociedade. Ao designar seus referentes, os políticos podem levar à presença de seu auditório (os eleitores em geral) características qualificativas ou desqualificativas, em conformidade com sua posição. Essa atitude possibilita ao auditório um olhar e um julgamento a respeito do objeto designado. Em relação a isso, Charaudeau (2006a, p.46) aponta que:

[...] toda informação a respeito de uma crença funciona ao mesmo tempo como interpelação do outro, pois o obriga a tomar uma posição com relação à avaliação que lhe é proposta, colocando-o em posição reativa - o que não é necessariamente o caso da informação que se refere aos conhecimentos.

Ainda de acordo com esse autor, os saberes de conhecimentos e de crenças constituem-se dentro de um processo de representação, isto é, são organizados por meio de imagens mentais transpostas em discurso e apresentadas como se fossem o próprio real. Vale frisar que as palavras apontam para essas representações, tanto para avaliar, quanto para julgar e (des) qualificar. Isso nos permite afirmar que a escolha lexical, possivelmente uma ação não ingênua, é portadora de valores.

Interessa-nos também ressaltar, quanto à argumentação, a respeito dos efeitos de verdade constituídos no e pelo discurso. Como já foi mencionado, Perelman e OlbrechtsTyteca $(1958,2002)$ baseiam seus estudos na noção de verossimilhança, que o discurso deve buscar para alcançar a adesão desejada. Também vimos com esses estudiosos, que o orador cria uma imagem daquele a quem visa convencer e/ou persuadir e tende a desenvolver discursos que privilegiam as verdades pressupostas como aceitas pelo esse auditório, objetivando chegar a um acordo.

Charaudeau (2006a) também faz menção ao efeito de verdade. Para ele, esse efeito está mais para o parecer, o acreditar, do que para o ser. O efeito de verdade é um produto da 
relação entre o sujeito e o mundo, entre o sujeito e o seu auditório, pois a "verdade” é determinada conforme seja compartilhada entre as pessoas.

Dessa maneira, os efeitos de verdade são constituídos também na interação, discursivamente, sendo que todos os elementos anteriormente mencionados estão imbricados: os conhecimentos, as crenças e os valores, o entorno social e histórico de cada participante. Para Charaudeau (2006a, p. 49):

O efeito de verdade não existe, pois, fora de um dispositivo enunciativo de influência psicossocial, no qual cada um dos parceiros da troca verbal tenta fazer com que o outro dê sua adesão a seu universo de pensamento e verdade. O que está em causa aqui não é tanto a busca de uma verdade em si, mas a busca de "credibilidade", isto é, aquilo que determina o "direito à palavra” dos seres que comunicam, e as condições de validade da palavra emitida. (grifos do autor)

Levando em conta a afirmação anterior, ressaltamos que nos debates políticos instaura-se uma disputa de “verdades”, um jogo discursivo pelo qual o julgamento ficará nas mãos do auditório. A credibilidade alcançada será um fator significativo para conseguir a adesão.

Charaudeau (2006b) ainda aponta sobre os imaginários de verdade, ou seja, aqueles discursos que assimilam determinados valores (liberdade, justiça, benevolência, igualdade etc) resultantes de representações imaginárias construídas e vistas positivamente por grupos sociais, ou comunidades. Entre eles, o autor enfoca três imaginários recorrentes na troca linguageira entre políticos e colaboradores na disputa entre as "forças de verdade": o da tradição, o da modernidade e o da soberania popular.

O imaginário da tradição sustenta-se por discursos que prezam pelos acontecimentos de tempos longínquos, pela busca de origens. O apelo a esse tipo de discurso possibilita a retomada de valores que, em um momento passado, foram assimilados por determinada sociedade e motivaram certas atitudes caracterizadoras de uma identidade de grupo. Em 
outras palavras, mantém-se uma "linha de crença” (Charaudeau, 2006b, p.212) que transcende à história, mantendo o elo das gerações.

O discurso da tradição pode valorizar a natureza, a pureza, a fidelidade e a responsabilidade. A primeira corresponde a uma maneira de apresentar os sujeitos como criaturas regidas por leis, aproximando-os das espécies animais que defendem seu espaço. A segunda (pureza) define-se como a busca de identidade, ou seja, a apresentação da origem de certos grupos, suas causas fundadoras e seus objetivos principais. Já a terceira (fidelidade) está relacionada aos valores morais e aos deveres assumidos pelos sujeitos de acordo com sua “herança moral”. Em relação à responsabilidade, podemos dizer que esta é o sentimento que obriga os integrantes de um grupo a agir de acordo com seus objetivos e seus valores morais, conservando sua história.

De maneira geral, o imaginário da tradição colabora tanto para justificar certas ações, quanto para questioná-las, (des) qualificá-las. Salientamos, de nosso corpus, o segmento às linhas 1125-1134 para ilustrar a questão do imaginário da tradição:

J.E.C. [...] eu tenho CERteza que o presidente está preserVAdo... rigorosamente preservado desse escândalo e tem dados sinais muito CLAros na LInha é:: disso como disse invesTIR em mim vamos cortar na própria CARne” que é o coMANdo que ele tem dado a nós... e nós vamos seguir isso fielmente porque o PT construiu...durante vinte e cinco anos um patrimônio ético... e eu não tenho a menor dúvida... que a melhor maneira de nós mantermos esse patrimônio... é cortamos como diz o presidente "na carne”... assim que se comprovar o envolvimento de alGUÉM... do PT... militante dirigente parlamentar... ( ) nós temos que ser INtolerantes com aqueles que transgridem a ética e até tenho dito mais Markun... nós temos que ser TÃO ou MAIS intolerantes com aqueles do PT que transgridem a ética [...]

Nesse segmento, José Eduardo Cardozo (J.E.C.), do Partido dos Trabalhadores, ao ser questionado sobre o possível conhecimento do Presidente Lula a respeito do envolvimento de petistas em denúncias de corrupção, refere-se ao seu partido “o PT” como possuidor de “um patrimônio ético”. Sobre isso, apontamos que essa expressão enfatiza os valores do partido 
como baseados na ética. Além disso, a atitude lingüística do locutor apresenta a origem do PT, levando o conhecimento, ou a lembrança, sobre a história do partido e de sua ideologia ao auditório em questão.

Em seguida, o enunciador (J.E.C.) retoma "um patrimônio ético" (linha 1129) por meio da formulação "esse patrimônio" (linha 1130), encaminhando seu discurso de maneira a apresentar as atitudes visadas pelo Presidente e pelos membros do PT em relação aos acusados de corrupção. Interessa-nos observar que a valorização da ética é evidenciada durante o seu turno, principalmente na maneira como são mencionados os referentes e suas devidas punições: “aqueles que transgridem a ética” (linhas 1133-1134), "aqueles do PT que transgridem a ética” (linha 1134). Isso faz com que se fortaleça o imaginário da tradição do partido e da "herança moral” (Charaudeau, 2006b).

Já no segmento de César Borges (C.B.), do PFL, observamos a organização de um discurso que também privilegia o imaginário da tradição; entretanto, o enunciador utilizou-se dessa estratégia para desqualificar e questionar a ação do governo e do Partido dos Trabalhadores, como se observa às linhas 276-280 do corpus:

C.B. eu conclamo que inclusive muitas vezes o Partido dos Trabalhadores... que deixa essa postura de desqualificar testemunhas... e procurem simplesmente fazer o trabalho de investigação... Abra efetivamente nesse momento... as suas enTRAnhas... para que nós possamos esclarecer para a nação... o que aconteceu inclusive com esse partido... importante partido da República brasileira

Nesse segmento, César Borges (C.B.) reportar-se à atitude de alguns petistas de desqualificar testemunhas na Comissão Parlamentar de Inquéritos. Se nos detivermos nas formulações lingüísticas selecionadas pelo enunciador “esse partido" e "importante partido da República brasileira” (linha 280), considerando todo processo interacional, já poderemos detectar que o enunciador utiliza-se da tradição do partido (sua história) para convalidar que o 
comportamento de alguns membros do PT não se coaduna com a "herança moral” (valores, origens) do partido.

O segundo imaginário de verdade apontado por Charaudeau (2006b) como estratégia utilizada de maneira recorrente em discursos políticos é o da modernidade. Neste caso, tratase de um conjunto de representações que certos grupos constroem a partir de um julgamento do momento presente, tomando como base a época precedente e realizando uma comparação.

Esse imaginário opõe-se ao da tradição, pois visa a romper com certos valores, e com determinadas maneiras de pensar e de agir. Os discursos da modernidade, segundo esse estudioso, caracterizam-se pela transformação, pela imagem do poder-fazer e do saber-fazer. Conseqüentemente, essa construção imaginária também estabelece uma relação entre utopia/sonho versus ação, apresentando a última como único meio de concretizar a primeira. É possível identificar nos turnos de Maurício Rands (M.R.) e de César Borges (C.B.), às linhas 873-888 do texto em anexo:

M.R. eu quero saBER... eu quero saBER... por que é que por que... é que alguns setores do PFL que ANtes de defenderem a reforma política... já estão dizendo agora... "não não quero mais fazer a reforma polí::tica... vamos esquecer outro momento" parece que quer o quê?... que o Brasil continue assim? é por isso que os senhores... é/rejeitam todas as mudanças que querem ser feitas

C.B.

( ) súbitos interesses de reforma política porque os senhores... estão aí com uma bancada de réu de responder... e induzir ( ) na campanha eleitoral de dois mil e dois de há muito tempo inclusive... que o PT vem (abordando) essas práticas... tem o caso do Santander ( ) tem a CPMI dos Bingos ( )

M.R.

súbitos interesses NÃO... senador... quando eu era... senaDOR... eu era presiden::te da Comissão de Constituição e Justiça sabe o que que eu fiz? Quando... senador... eu era presidente... da Comissão de Constituição e Justiça... quando eu estava quando eu estava na presiDÊNcia da (CCJ) sabe qual foi a matéria que eu elegi como prioriDAde além da reforma do processo da justiça ser mais rápida para o brasileiro? foi a reforma política [...] 
Nesse segmento, Maurício Rands (M.R.), do PT, apresenta a proposta de reforma política como possibilidade de melhoria, de avanço do quadro atual do país. Assim também, questiona os motivos pelos quais os políticos do PFL negam esse projeto de reforma. Sobre o procedimento de M.R., observamos que seu discurso defende a modernidade, a transformação, em que o governo é possuidor do saber-fazer, porém, não alcança o poderfazer por conta da atitude dos políticos da oposição.

Essa posição de Maurício Rands é avaliada por César Borges (C.B.) como "súbitos interesses de reforma política” (linha 879). Em contrapartida, e rapidamente, o petista reage por meio da expressão “súbitos interesses NÃO” (linha 884), enfatizando sua opinião contrária a do senador e, em seguida, encaminhando sua defesa em resposta à acusação. De maneira geral, os procedimentos de ambos tornam evidente a disputa de idéias, em que a modernidade é defendida por um, e questionada por outro.

O último imaginário, o da soberania popular, apresenta a população como objeto soberano capaz de julgar e de opinar. Como afirma Charaudeau (2006), esse imaginário é o mito da democracia, em que se cria o efeito de que a voz da sociedade é valorizada. Dessa maneira, opondo-se à valorização da origem (tradição) e à transformação de um mundo ideal (modernidade), esse imaginário volta-se à justiça e à lei e, consecutivamente, inscreve-se na imagem de soberania popular e dos direitos à identidade, ao igualitarismo e à solidariedade. Um exemplo disso ocorre às linhas 118-125 do texto em anexo:

M.R. eu penso que:: o que a sociedade quer... éh:: que o Brasil funcione...para o Brasil funcioNAR... para que:: as instituições do Estado... resolva os problemas da população... um dos GRANdes obsTÁculos...é::... o fenômeno da corrupção... e:: a sociedade quer Paulo que:: NEsse episódio...TOdos que cometeram irregularidades sejam puni::dos... o que a sociedade quer o que nós queremos...é que TOda a verDAde... seja trazida... para todos os brasileiros... e brasileiras... mas a sociedade quer um pouco MAis... ela quer que nós teNHAmos a capacidade de fazer as muDANças institucionais... SEjam aquelas do funcionamento da administração pública... sejam aquelas do funcionamento do sisTEma político [...] 
No segmento de Maurírio Rands (M.R.), a repetição do referente “a sociedade” (linhas 118,120,121,123), “todos os brasileiros e brasileiras” (linhas 122-123) é elemento indicativo da estratégia utilizada pelo enunciador, ou seja, aquela que privilegiou a voz da população, encaminhando para a valorização da justiça e da lei.

De maneira geral, podemos dizer que os discursos produzidos por políticos, ou mesmo por grupos políticos, situam-se em posições distintas. Enquanto, em determinado momento da interação, um defende uma posição tradicionalista, o outro certamente construirá enunciados que prezam pela transformação. Isso ocorre devido à disputa discursivo-argumentativa própria dessa situação social, em que a elaboração de enunciados tem como propósito alcançar o maior número de indivíduos para fazê-los aderir aos efeitos de verdade defendidos por cada político.

\subsection{O papel da argumentação no discurso (de) político}

Por tudo o que apresentamos até agora, torna-se evidente que todo enunciado é produzido na relação instaurada entre os falantes no evento em que determinada interação está situada, sendo que esta já implica objetividades.

Em relação a essa intencionalidade do encontro, sabemos que, em algumas interações, principalmente naquelas relacionadas aos debates políticos na mídia, os interactantes almejam mais do que informar e/ou expor opiniões; eles desenvolvem seus enunciados com o principal intuito de convencer e persuadir um público específico: a audiência.

Nessas situações de debate, é perceptível o jogo argumentativo instaurado, em que argumentos são confrontados e, por esse motivo, ajustam-se, modificam-se durante o desenrolar do diálogo, num processo de co-produção, co-argumentação. Perelman e 
Olbrechts-Tyteca (1958, 2002, p.231) fazem menção a essa construção dinâmica da argumentação:

Enquanto o orador argumenta, o ouvinte por sua vez, ficará inclinado a argumentar espontaneamente acerca desse discurso, a fim de tomar uma atitude a seu respeito, de determinar o crédito que lhe deve dar. O ouvinte que percebe os argumentos não só pode percebê-los a sua maneira como é o autor de novos argumentos espontâneos, o mais das vezes não expressos, mas que ainda assim intervirão para modificar o resultado final da argumentação.

Dentro dessa afirmação, os enunciados estão diretamente ligados a outros, antecedentes ou posteriores. Dessa maneira, durante a interação, os contextos se modificam e, sucessivamente, os discursos podem tomar outros direcionamentos; tudo dependerá da situação discursiva constituída pelos participantes.

Nos debates entre políticos, a atitude lingüística-argumentativa de cada um também dependerá da tripla relação instituída na interação: o político e a audiência, o político e o partido que ele representa e o político e os seus adversários, estabelecendo-se um jogo de relações intersubjetivas.

A primeira relação refere-se aos eleitores, aqueles que o orador visa a convencer e a persuadir. Nesse caso, ele deve prever a opinião pública, como sendo favorável ou desfavorável, ou até mesmo incerta, e adaptar seu discurso de acordo com a imagem prevista.

Como também o político sempre falará em nome de algum partido e sua imagem estará em ligação de coexistência entre a pessoa e o grupo, Perelman e Olbrechts-Tyteca (1958, 2002) mencionam que essa relação, geralmente, é a mais freqüente, pois o membro é a manifestação de seu grupo e vice-versa.

Assim, por suas atitudes, os sujeitos influenciam a imagem do seu grupo e esta, por sua vez, será atribuída a todos os membros. Salientamos que se trata de uma associação, uma 
relação metonímica em que o todo, o partido, dá-se pela parte, e vice-versa, estabelecendo um contínuo, em que o julgamento de um político chegará aos outros participantes.

O outro tipo de interlocutor é o adversário político. Ele pode ser um oponente de campanha eleitoral, um membro de outro partido ou, inclusive, aqueles que se fazem adversários na relação de interação, por algum acontecimento ou tema abordado.

Nessas relações, os políticos tenderão a desqualificar a imagem do adversário e de seu grupo. Isso dá pela exaltação da própria imagem e pela desqualificação da imagem do outro. Em decorrência disso, se cada debatedor estiver atento às suas falas, visando a surtir efeitos na construção de seus discursos de acordo com seu projeto de dizer, fará uso dos recursos da língua e tenderá organizá-los de maneira a conseguir a adesão pretendida.

Aquino (2005, p.108-109) afirma que:

Nenhum político aceita ingenuamente um convite para participar de um programa televisivo ou radiofônico, seja ele de entrevistas ou debates. $\mathrm{O}$ contexto que se apresenta é de conhecimento dos participantes: entrevistador/entrevistado, condutor de debates/convidados. Crenças, opiniões, valores, atitudes, interesses e objetivos podem ser diversos entre os participantes, o que nos permite dizer que nem sempre está garantida uma interação bem-sucedida.

Incluímos ainda nesse quadro o fato de que a televisão é uma mídia de grande alcance, que permite a interação entre milhares de pessoas. Isso colabora para que os debates políticos se tornem, por excelência, o lugar de disputas de idéias e, consecutivamente, o momento de troca de argumentos.

Ainda sobre esse ponto, é preciso considerar que os discursos elaborados por políticos enquadram-se em um domínio de prática social detentor de relações de disputas, cujo objetivo principal é a gestão de um poder. O político deve, pois, conquistar credibilidade e identificação; para tanto, é necessário convencer e persuadir um número significativo de pessoas. 
O exercício do convencimento e da persuasão torna-se possível na prática discursiva, pela utilização de estratégias argumentativas - como os processos de referenciação ${ }^{15}$-, na organização do discurso e na maneira de apresentá-lo. Portanto, o discurso pode direcionar olhares, atribuindo valores que podem ser aceitos e/ou compartilhados por uma sociedade.

Além disso, o contexto sócio-histórico e a imagem que um político constrói de si, no decorrer de sua carreira, também são elementos que podem interferir no momento da disputa discursiva.

Juntamente com todos esses elementos mencionados, ressaltamos que a sociedade possui instituições que organizam e possibilitam a interação entre sujeitos, seja no campo da educação, seja no campo político. Há funções sociais que autorizam o orador a tomar a palavra e a explanar sobre certos assuntos diante de específicos auditórios.

Na posição de falante, o sujeito autorizado elabora enunciados que comportam expressões ou palavras que, além de informar, carregam certa carga de juízo de valor que podem conduzir a orientações argumentativas.

Deve-se, neste ponto, ressaltar o fato de que as palavras não são portadoras de um sentido estrito. Ao contrário disso, na prática discursiva, elas são dotadas de ideologias e de valores socialmente reconhecidos; portanto, vestem-se de carga argumentativa. Quando utilizadas no discurso, interagem com a situação na qual este se insere e com os outros elementos lingüísticos do enunciado, possibilitando uma “plasticidade” (Guimarães, 1999) em relação aos seus sentidos.

\footnotetext{
${ }^{15}$ Reservamos o capítulo III deste trabalho para a discussão sobre os processos referenciais como estratégia argumentativa.
} 


\subsection{A apresentação do referente como escolha argumentativa}

Por vezes, a escolha de um termo será destinada a servir de indício, indício de distinção, de familiaridade ou de simplicidade. Por vezes, ela se servirá mais diretamente à argumentação, situando o objeto do discurso numa categoria. (Perelman e Olbrechts-Tyteca, 1958, 2002, p.169)

Para Perelman e Olbrechts-Tyteca $(1958,2002)$, pensar em palavras sinônimas, com certo grau de familiaridade, seria mais plausível se relacionadas àquelas dicionarizadas. No discurso, a utilização de termos sempre estará interagindo com os contextos, ligando-se, assim, diretamente à argumentação. Isso ocorre mesmo com aquelas expressões que aparentam neutralidade, pois já o fato de selecioná-las indica uma intencionalidade.

Assim, ao selecionar certas características de um objeto, inseri-las em um co-texto e apresentá-las ao auditório, o locutor estará optando por uma escolha lingüística que comporta valores argumentativos. Sobre esse ponto, o recorte enfatizado levará à presença do auditório um conhecimento, ou um ponto de vista, que completará ou mesmo servirá de sugestão na construção da imagem do objeto referido. De acordo com esses estudiosos:

O fato de selecionar alguns elementos e apresentá-los ao auditório já implica a importância e a pertinência deles no debate. Isso porque semelhante escolha confere a esses elementos uma presença, que é um fator essencial da argumentação. (Perelman e Olbrechts-Tyteca, 1958, 2002, p.132)

Consideramos, também, nesse campo de ação comum, que certas marcas lingüísticas vão tecendo os enunciados, direcionando-os de maneira que o interlocutor chegue a certas conclusões. Isso evidencia que os falantes utilizam-se de estratégias discursivas para convencer e/ou persuadir seu interlocutor, ou seja, textos são produzidos baseados em escolhas, de acordo com os objetivos de cada participante.

Em outras palavras, determinadas formulações lingüísticas comportam cargas de valores que, ao interagirem com o auditório, podem levar à qualificação ou à desqualificação daquilo sobre o que se referem. Isso pode se dar com a utilização de adjetivos qualificativos, 
de nomes de classes (substantivos comuns) e, até mesmo, nomes próprios. Todos esses presentes em expressões nominais ${ }^{16}$ definidas e indefinidas (descrições, nominalizações etc).

Perelman e Olbrechts-Tyteca expõem a importância da escolha lingüística na argumentação. Os autores afirmam que certas palavras ou expressões, como os epítetos, enfatizam uma propriedade do referente, conferindo a este o sentido de fato. Nas palavras dos estudiosos: "Esse epíteto é utilizado sem justificação, porque se presume que enuncia fatos incontestáveis. Apenas as escolhas desses fatos parecerão tendenciosas”. (1958, 2002, p.143)

A qualificação ou a desqualificação pode ser constituída progressivamente pelo conjunto de recortes do referente que se faz presente no discurso, evidenciando que essas escolhas implicam intenções argumentativas as quais podem ser modificadas ou reforçadas pelos participantes durante a atividade discursiva.

Quanto a isso, tomemos o segmento extraído do nosso corpus (linhas1194-1208):

C.B. [..] veja... você tem o Banco do Brasil... Henrique Pizzolato... o Banco do Brasil gastou no ano de dois mil e quatro duzentos e quarenta milhões de reais de publicidade... quem é a agência? SMP\&B né... então o tempo é curto eu vou encerrar... mas nós temos o problema do GameCorp também que é outra denúncia grave a ser apurada de tráfico de influência... então há com gran::de tráfico de influência... DENtro deste governo prejudicial a gestão da coisa pública no país... mas que o presidente tem responsabilidade TEM

P.M. Maurício Hands

M.R. sabe qual é a diferença? é que este governo... sabedor da realidade do EsTAdo brasileiro... o que surge... o que tem de denúncia... ele manda apurar... eu vejo infelizmente mui::to jogo de cena... eu vejo lá quantas CPIs lá no governo do governador César Borges foram permitidas na Assembléia Legislativa ou de outro modo quantas foram abafadas...esse governo e aí a senadora Ideli Salvatti está muito correta... TOdas as denúncias que surgem este governo está investigando... por isso foi aquele que fez MAIS operação da Polícia Federal... aquele que fortaleceu a Controladoria Geral da União... aquele que está indo a fundo... e cortando na própria carne...

\footnotetext{
${ }^{16}$ Reservaremos uma parte do próximo capítulo para discutir sobre as expressões nominais referenciais e seus efeitos argumentativos em razão da necessidade de uma discussão mais detalhada a respeito das estratégias de referenciação.
} 
Nesse segmento, César Borges julga o governo como "prejudicial a gestão da coisa pública no país” (linhas 1198-1199), o que desqualifica o referente em questão. Por outro lado, Maurício Hands, deputado do Partido dos Trabalhadores, retoma o objeto “este governo” e seleciona a avaliação “sabedor da realidade do Estado brasileiro” (linha 1201). Dessa maneira, o enunciador apresenta o governo atual (de Lula, do PT) como possuidor do saber e, por esse motivo, com competência para atuar no campo da política.

O procedimento de M.R. é mantido e reforçado por meio de descrições que levam à presença do auditório as ações do governo que visam a combater a corrupção: “aquele que fez MAIS operação da Polícia Federal” (linha 1206), “aquele que fortaleceu a Controladoria Geral da União” (linhas 1206-1027), “aquele que está indo a fundo e cortando na própria carne” (linhas 1207-1208).

Observamos também que a escolha lingüística leva a uma classificação, ou a um rótulo, podendo despertar no auditório ações positivas ou negativas. Ao designar uma pessoa ou um acontecimento, o falante estará incluindo seu referente em uma classe, em uma categoria. Isso pode ocorrer com a utilização de expressões nominais definidas ou indefinidas.

Sobre isso, ainda ressaltamos a utilização de “definições oratórias” (Perelman e Olbrechts-Tyteca, 1958, 2002) como significativa escolha argumentativa. Segundo esses estudiosos, as definições possibilitam pôr em destaque determinadas características do referente que poderiam passar desapercebidas pelo auditório. Assim, como os epítetos (mencionados à página 73), as definições oratórias colaboram para a caracterização dos referentes textuais, incluindo-os em categorias e, consecutivamente, apresentando-os de maneira a qualificá-los ou desqualificá-los.

A seguir, mais um exemplo, extraído do nosso corpus, em que César Borges, deputado do partido PFL, expõe sua opinião sobre a questão do “caixa dois”, termo usado no campo 
político para designar as transações de dinheiro, concedido a partidos políticos, sem as devidas declarações legais. Observemos às linhas 98-107:

C.B. olha as:: declarações que nós assistimos este final de semana parece ser algo que está concatenado... de um lado... o presidente da República...coloca sobre::...o financiamento de campanha um problema... por outro lado... o senhor Marcos Valério vem com sua terCEira versão... também dizendo até que o empréstimo foi pessoAL... e feito...ao senho::r Delúbio Soares... e não ao partido em determinado momento ele declara isso... e vem seu Delúbio Soares dizendo que como essa prática também é normal... então:: ficaria com relação ao financiamento de campanha a grande cul::pa dessa situação... eu acho que isso é uma cortina de fumaça... não é verdade... nós estamos num momento de averiGUAr com... PROfundidade ((tosses)) o porquê dessas questões... não é? efetivamente...aí... HÁ dinheiro público envolvido... não é um mero financiamento de campanha... que pode ser feito legalmente[...]

Nesse exemplo, o demonstrativo “isso" refere-se aos pronunciamentos tanto do Presidente da República, quanto de Marcos Valério em relação às denúncias de desvios de dinheiro público. Para proceder a uma desqualificação dessas declarações, César Borges (C.B.) utilizou-se de definições, como: “é uma cortina de fumaça”, “não é verdade” e “não é um mero financiamento de campanha” (linhas 104, 105 e 107).

Sobre o procedimento de C.B., observamos que as definições selecionadas possibilitaram, no desenvolvimento do discurso, a orientação de sentido, colocando as declarações de Lula e de Marcos Valério como duvidosas, desqualificando-as. Depreendemos também, à linha 102, a seleção da expressão “com sua terceira versão” que corrobora as acusações feitas por César Borges. Em outras palavras, entre as categorias da verdade e da mentira, o enunciador nega a primeira para exaltar a segunda, imprimindo valores extremamente negativos à atitude lingüística avaliada.

Importa-nos ressaltar que o orador, ao utilizar uma definição, iniciando-a com um termo negativo, como o “não é”, estará negando uma afirmação já feita anteriormente, seja na situação de interação, utilizando-se do recurso metadiscursivo, seja no contexto social e histórico. 
Olerón (1983) afirma que qualificar é um ato de classificar, sendo que, por vezes, sua efetivação dependerá dos valores do auditório, isto é, as classificações circulam, em específicas sociedades, dotadas de valores ora positivos, ora negativos. Os conceitos já formados por determinados grupos a respeito de certas classificações definirão o tratamento e o julgamento conferidos a elas por um auditório. Dessa maneira, a escolha lingüística tenderá a ser sempre provida de intenção argumentativa. De acordo com o autor (1983, p.109):

A qualificação é um argumento, visto que intervém para determinar a decisão do juiz ou do júri. Mas também a consequência de uma argumentação: a análise dos fatos e sua relação com os textos legais é que vão fixá-la.

Interessa-nos frisar que as classificações podem ser negociadas durante a atividade interacional, de maneira a serem contestadas e, assim, modificadas, apresentando outras classes julgadas mais adequadas. Dessa maneira, o sentido é construído progressivamente e pode ser orientado pelas características (dos objetos) selecionadas pelo orador. Essa negociação é possível pela própria organização interna da língua, na progressão dos enunciados, no processo referencial constituído, principalmente, pela seleção de expressões nominais definidas ou indefinidas. O próximo capítulo tratará sobre esse assunto. 


\section{CAPÍTULO III}

A referenciação como processo constitutivo de orientações argumentativas 
The world is not ready categorized by God or nature in ways that we are all forced to accept. It is constituted in one way or another as people talk it, write it and argue it.

Jonathan Potter

Nos capítulos anteriores, observamos que a construção de sentido se dá na situação discursiva, na interlocução entre os participantes, por meio dos conhecimentos, das crenças e dos valores que cada sujeito constitui e armazena durante sua experiência de vida. Esses elementos manifestam-se na língua, e esta, constituída como discurso, possibilita que os falantes adequem suas falas segundo seu projeto de dizer e a intencionalidade do encontro.

\subsection{A referenciação como construção discursiva da realidade}

Acreditamos numa concepção de realidade que vai além dos fatores empíricos do mundo. Sobre esse ponto, podemos afirmar que é pelo complexo sistema, que envolve língua, pensamento e mundo, que os sujeitos, condicionados pela sua própria percepção, dão sentidos aos seus referentes, durante a formulação de seus enunciados.

Consideramos, portanto, que a língua não é reflexo da realidade, pois esta pode ser apreendida diversamente por sujeitos distintos. Essa perspectiva enquadra-se nos recentes estudos sobre a referenciação (Mondada, 2001, 2002, 2005; Mondada e Dubois, 2003; Apothéloz, 2003; Marcuschi e Koch, 1998; entre outros), que vêm apresentando uma nova concepção entre língua e mundo. Nesse quadro, os referentes, tidos como imagens mentais, são fabricados pela dimensão perceptivo-cognitiva dos interactantes na prática social, e a língua é um recurso para a construção intersubjetiva de categorias avaliativas, que se modificam durante determinadas interações.

Os apontamentos anteriores têm como base alguns pressupostos. O primeiro deles é a concepção de língua heterogênea, opaca, histórica, variável e socialmente constituída (Koch e 
Marcuschi, 1998). Em outras palavras, ela não é nem transparente e nem instrumento de espelhamento do mundo. Dessa maneira, a língua não é algo pronto, mas um recurso que possibilita a construção discursiva da realidade.

O segundo pressuposto - também apontado por Koch e Marcuschi (1998) - refere-se à condição dinâmica e cognitiva da construção de referentes, isto é, à realidade extra-mental que é designada por meio de uma ação lingüística, social, criativa e cognitiva. Por esta última, podemos afirmar que a percepção cognitiva da realidade está diretamente ligada aos pontos de vista do sujeito que, pela sua capacidade de designação, transforma o real em referente.

Blikstein (2003) também afirma que, ao observarmos essa capacidade dos sujeitos de designar “objetos mentais ou unidades culturais”, devemos levar em conta a necessidade de um olhar além da dimensão verbal, pois o sentido fabricado na atividade referencial, por meio da língua, não é de fato a apreensão da realidade em si, mas uma percepção-cognitiva desta que torna possível o evento semântico/discursivo.

Ainda de acordo com esse autor, é na dimensão da práxis que o sujeito, ser agente e cognoscente, desenvolve mecanismos de diferenciação e de identificação a respeito da “realidade empírica” (Blikstein, 2003), ou seja, dentro de determinado contexto culturalcomunitário, os sujeitos traçam diferenciais com os quais se tornam aptos a reconhecer e selecionar cores, formas, funções, atividades, entre outros. Por meio desse processo perceptivo/cognitivo, esses traços adquirem valores positivos (meliorativos) em oposição a valores negativos (pejorativos), conforme certas práticas, ou vivências sociais, tornando-se, assim, percepções ideológicas. Sobre esse ponto, o estudioso afirma:

Os traços ideológicos vão desencadear a configuração de "fôrmas" ou "corredores" semânticos, por onde vão fluir as linhas básicas de significação, ou melhor, as "isotopias" da cultura de uma comunidade ${ }^{17}$. (Blikstein, 2003, p.60-61)

\footnotetext{
${ }^{17}$ Grifos do autor.
} 
Segundo Blikstein (2003), em nossa cultura ocidental, há corredores isotópicos responsáveis pela criação de padrões perceptivos, ou “óculos sociais” como:

\begin{tabular}{|c|c|}
\hline Valores positivos/meliorativos & Valores negativos/pejorativos \\
\hline Superatividade & Inferatividade \\
\hline Frontalidade & Posterioridade \\
\hline Retitude & Tortuosidade \\
\hline Dureza & Moleza \\
\hline Branquitude & Pretidão \\
\hline $\begin{array}{c}\text { Verticalidade } \\
\text { (em pé, alto, altivo) }\end{array}$ & $\begin{array}{c}\text { Horizontalidade } \\
\text { (caído, deitado, abaixo) }\end{array}$ \\
\hline
\end{tabular}

Quadro 04. Os corredores isotópicos de Blikstein.

Esses corredores isotópicos (quadro 04) determinam os padrões perceptivos que, por sua vez, geram estereótipos culturais/sociais. Em outras palavras, eles, geralmente, estabilizam a maneira de vermos o mundo, pois estão configurados na interpolação: sujeito/práxis/discurso/referente. Isso se deve ao fato de essas ideologias sociais dominantes estarem enraizadas no próprio processo de significação presente também na discursivização do “extra mental”, ou seja, na ação de significar o mundo por meio da linguagem.

Assim, o referente textual não pode ser entendido como a própria realidade exterior e, nesse sentido, importa indicar a noção de referente conforme Mondada e Dubois (2003). Essas autoras denominam objetos de discurso, em oposição a objetos de mundo, os elementos do mundo empírico, mencionados no discurso. Segundo essas estudiosas:

[...] as categorias e os objetos de discurso pelos quais os sujeitos compreendem o mundo não são nem preexistentes, nem dados, mas se elaboram no curso de suas atividades, transformando-se a partir dos contextos. Neste caso, as categorias e objetos de discurso são marcados por uma instabilidade constitutiva, observável através de operações cognitivas ancoradas nas práticas, nas atividades verbais e não-verbais, nas negociações dentro da interação. (Mondada e Dubois, 2003, p.17) 
As autoras indicam que, nas práticas discursivas, os sujeitos sociais fabricam objetos de discurso durante a situação interacional. Isso é possível através de escolhas lingüísticas que inserem os referentes textuais em categorias, mais ou menos, estabilizadas por estereótipos culturais e sociais ${ }^{18}$.

A instabilidade constitutiva, apontada por Mondada e Dubois (op.cit.), refere-se às negociações que se fazem necessárias em determinados encontros. Nestes, os sujeitos vão adaptando seus enunciados de acordo com a ação e a reação dos outros participantes, sendo que, por vezes, o objeto mencionado é inserido em categorias que se adaptam, constantemente, à situação de interação.

A organização e a progressão textual permitem que as categorias sejam ajustadas ou reforçadas no enunciado. Em relação a isso, dois processos estão imbricados: a topicidade e a seqüencialidade. O primeiro refere-se à progressão tópica, aos assuntos abordados durante a atividade discursiva; já o segundo relaciona-se à progressão referencial, denominada estratégia de referenciação.

Esses dois processos podem estar relacionados, se pensarmos a designação de referentes como base do desenvolvimento de um tópico discursivo ${ }^{19}$, sendo que este também pode direcionar ou demarcar a continuidade referencial; entretanto, manter o tópico durante a interação, apesar de facilitar, não garante a progressão referencial.

Os processos de textualização, além de distintos e complementares, podem ser codeterminantes, ou seja, em algumas situações, a interpretação de um referente textual podese dar por meio do tópico discutido na interação.

\footnotetext{
${ }^{18}$ A respeito dos estereótipos culturais e sociais, lembremos da tabela de Blikstein (2003) indicada à página 82 deste capítulo.

${ }^{19}$ Consideramos a noção de tópico discursivo conforme a proposta do Grupo da Gramática do Português Falado (1992). Para este, o tópico, elemento significativo para a progressão do texto falado, é apresentado como o (s) assunto(s) da situação interativa, ou seja, sobre o que os falantes conversam. Esses assuntos estão ligados de maneira intrínseca e organizados em dois planos: linear (seqüência horizontal, adjacente) e hierárquico (relacionado à abrangência do assunto).
} 
Apesar de considerarmos os dois processos - topicidade e seqüencialidade - como base da progressão dos enunciados, voltaremos nossa atenção, neste trabalho, aos processos referenciais e ao fato de como estes possibilitam o direcionamento de sentido e a orientação argumentativa, dada a construção de objetos de discurso.

\subsection{A estratégia referencial e as orientações argumentativas}

De acordo com Koch (2006b), há alguns princípios de referenciação envolvidos na construção de um modelo textual:

1. Ativação: um referente textual até então não mencionado é introduzido, passando a preencher um nódulo (endereço cognitivo);

2. Reativação: o nódulo é novamente ativado na memória;

3. De-ativação: ativação de um novo nódulo, deslocando a atenção para um outro referente textual e desativando aquele objeto que estava em foco. Entretanto, o seu endereço cognitivo continua no modelo textual, podendo ser ativado a qualquer momento.

Esses princípios são acionados continuamente na construção textual. Se, por um lado, a ativação e reativação de um nódulo estabilizam o modelo textual, por outro, poderá haver modificações, quando novas referenciações forem adicionadas. Isso se deve ao fato de, durante o processo de elaboração do texto, outros objetos serem introduzidos, ou mesmo, aqueles já apresentados receberem outras informações ou avaliações. Nas palavras de Koch (2006b, p. 83):

[...] durante o processo de compreensão, desdobra-se uma unidade de representação extremamente complexa, pelo acréscimo sucessivo e intermitente de novas informações e/ou avaliações acerca do referente. 
Ainda de acordo com Koch (2006b), o modelo textual não se caracteriza por uma continuidade progressiva linear. Sua progressão dá-se pela ativação de referentes textuais somados a outros apresentados anteriormente. É possível, assim, dizer que o texto é constituído pela soma progressiva de suas partes.

A progressão textual torna-se possível pela oscilação de vários elementos os quais têm como base: o que já foi dito (anáfora), o que será dito (catáfora) e o que é sugerido (fusões, alusões etc.). A isso, Koch (2006b) denominou “co-determinação progressiva”.

No caso da anáfora, os estudos a respeito dos processos referenciais rediscutem a concepção tradicional do termo. Se tradicionalmente o termo anáfora significava a ação de repetir, trazer de volta, isso se deve ao valor etimológico da palavra que foi traduzida do grego anapherein, oriunda do latim referre. Atualmente, para alguns estudiosos como Apothéloz (2003), Koch (2001, 2005, 2006a, 2006b), Marcuschi e Koch (1998), a anáfora é vista como recurso de progressão referencial e de construção de sentido do texto.

Nesse quadro, as anáforas possibilitam a retomada ou a remissão de referentes anteriormente mencionados ou inferidos no co-texto. Nesse sentido, a retomada anafórica é uma estratégia de progressão discursiva que, apesar de não implicar sempre uma relação correferencial, tida como o protótipo de anáfora, permite a continuidade referencial, fundamentada no processo de referenciação.

Essa concepção levou a pensar em anáforas associativas (Apothéloz, 2003; entre outros). Estas se caracterizam por não haver no co-texto um antecedente explícito, embora haja uma informação de relação fundamental para sua interpretação. Em outras palavras, os objetos de discurso são construídos e interpretados num processo cognitivo inferencial que ativa os conhecimentos na memória dos interlocutores, de maneira associativa. Desempenham, assim, um papel importante na estrutura coesiva do texto, como também, na argumentação. 
Por meio de todos esses elementos que possibilitam a "movimentação textual", também são estabelecidas as condições de textualização (Koch, 2006b), fazendo com que estas se renovem progressivamente. Em decorrência disso, a construção de sentido e a orientação argumentativa também podem ser renovadas.

Dessa maneira, o texto constitui-se por relações textuais seqüenciadas em que cadeias referenciais são construídas e procedem à categorização e à recategorização de objetos de discurso.

\subsubsection{A seleção de expressões nominais referenciais como estratégia argumentativa}

Ao dedicar-se aos estudos da progressão referencial, Koch (2005, 2006a, 2006b) destaca as expressões nominais, definidas e indefinidas, como significativas estratégias de referenciação com alto teor $\operatorname{argumentativo~}^{20}$, ao lado das pronominalizações. São denominadas expressões nominais definidas aquelas formulações lingüísticas constituídas por, pelo menos, um determinante definido ou demonstrativo, antecedendo um nome. Já as expressões indefinidas precedem artigos indefinidos ao nome. Destacamos que ambas as expressões podem aparecer como: descrições, nominalizações, rotulações metafóricas, metonímicas e metadiscursivas.

Entre essas várias maneiras por meio das quais as expressões nominais podem aparecer, ressaltamos que as descrições caracterizam-se pelas propriedades selecionadas de um referente textual. Em geral, o sujeito ativa traços do objeto que ele julga importante ressaltar, de acordo com o seu projeto de dizer.

\footnotetext{
${ }^{20}$ Essa posição coaduna-se, como vimos no capítulo anterior, aos estudos de Perelman e Olbrechts-Tyteca (1958, 2002), em que o papel da escolha lingüística é de grande valia para a argumentação.
} 
A utilização de descrições tanto pode revelar opiniões, crenças e ações do sujeito falante, quanto pode presentificar características do referente julgadas desconhecidas pelo interlocutor, isto é, a descrição aponta certos traços do objeto, resultando em um recurso lingüístico que colabora para a argumentação ou, mais especificamente, para o processo de orientação argumentativa.

No caso das nominalizações, que também cumprem a mesma função argumentativa das descrições e das definições ${ }^{21}$, salientamos que o nome, em geral, é acompanhado por um modificador $^{22}$, podendo seguir ou anteceder um demonstrativo ou um definido ou, até mesmo, uma estrutura comparativa. "Por meio da estratégia da nominalização erigem-se em objetos de discurso conjuntos de informações presentes no texto precedente”. (Koch, 2001, p.81).

Ainda, ressaltamos que as expressões nominais indefinidas colaboram, juntamente com as definidas, na construção progressiva do referente textual. Geralmente, elas ativam um objeto que será construído no desenrolar do enunciado. Como apontados anteriormente, as remissões por meio de expressões nominais são atividades da linguagem que possibilitam a (re) construção de referentes textuais. Também importa-nos frisar que uma de suas funções textual-interativas "é a de imprimir aos enunciados em que se inserem, bem como ao texto como um todo, orientações argumentativas conforme à proposta enunciativa do seu produtor” (Koch, 2005, p. 35).

Nessa perspectiva, a utilização de expressões nominais também possibilita a (re) categorização de segmentos precedentes ou subseqüentes do cotexto, de maneira a sumarizálos sob um determinado rótulo. Ainda de acordo com Koch (2005), nesses casos, esses elementos lingüísticos - intitulados como encapsulamentos e introduzidos, geralmente, por um demonstrativo - não nomeiam referentes específicos, mas aqueles “abstratos e freqüentemente

\footnotetext{
${ }^{21}$ No capítulo II, vimos que Perelman e Olbrechts-Tyteca $(1958,2002)$ apontam a seleção de definições oratórias como estratégia argumentativa, já que estas possibilitam a apresentação de determinadas características do referente textual, de maneira a qualificá-lo ou desqualificá-lo.

${ }^{22}$ Como os epítetos (Perelman e Olbrechts-Tyteca, 1958, 2002) indicados no capítulo II deste trabalho.
} 
genéricos e inespecíficos” (2005, p. 38), como: estado, fato, fenômeno, circunstância, condição, evento, atividade, hipótese etc.

Conte (2003), em seus estudos a respeito dos encapsulamentos, afirma:

O encapsulamento anafórico é um recurso coesivo pelo qual um sintagma nominal funciona como uma paráfrase resumitiva de uma porção precedente do texto. Esta porção do texto (ou segmento) pode ser de extensão e complexidade variada (um parágrafo inteiro ou uma sentença). (2003, p.178)

A autora ainda afirma que, por meio da utilização de encapsulamentos, um novo referente discursivo é criado sob a base de uma informação velha, tornando-se argumento de predicações posteriores. Dessa maneira, esse recurso lingüístico exige do interlocutor uma interpretação tanto da expressão lingüística selecionada para encapsular, quanto do segmento retomado.

Por todos esses elementos, o encapsulamento desempenha duas funções: a primeira corresponde à rotulação de um segmento do cotexto precedente; a segunda refere-se à criação de um novo referente que, possivelmente, tornar-se-á tópico para o(s) próximo(s) enunciado(s).

Em relação ao papel argumentativo dos encapsulamentos, estes além de reativarem, na memória do interlocutor, as informações anteriormente apresentadas, também podem imprimir novos valores (positivos ou negativos) aos fatos já mencionados, encerrando função avaliativa/persuasiva que colabora com a orientação argumentativa pretendida pelo produtor do texto. Sobre esse ponto, Koch (2005) afirma que se tratam de formas híbridas, ou seja, ao mesmo tempo são referenciadores e predicativos que trazem ao interlocutor tanto a informação dada, quanto a informação nova.

Ainda de acordo com Koch (2005), há dois tipos de encapsulamento. Aqueles que rotulam um segmento do enunciado, transformando-o em objeto-de-discurso e possibilitando 
a progressão textual, e aqueles que "realizam operações de nominalizações, por meio de nomes deverbais ou não” (2005, p. 39). No último caso, a autora afirma que:

[...] consistem em rotulações resultantes de encapsulamentos operados sobre predicações antecedentes ou subseqüentes, ou seja, sobre processos e seus actantes, os quais passam a ser representados como "objetos-acontecimento" na memória discursiva dos interlocutores. Do ponto de vista da dinâmica discursiva, apresenta-se, "pressupondo" sua existência, um processo que foi (ou será) predicativamente significado, que acaba de ser (ou vai ser) "posto”. (2005, p. 39-40)

Um outro tipo de rotulação corresponde à metadiscursividade, ou seja, aquela formulação lingüística que sumariza uma atividade de linguagem. Neste caso, como ocorre na utilização de encapsulamento, não há retomada referencial, já que o objeto tomado e possivelmente (des)qualificado é o próprio discurso.

Em outras palavras, o produtor do texto, ao utilizar o recurso de intertextualidade, inserindo segmentos de outros enunciadores, poderá não apenas trazê-los à memória do interlocutor, mas também, rotulá-los de acordo com seu projeto de dizer. Esse procedimento poderá resultar, na rede de sentido do texto, em valores persuasivos, conforme a expressão lingüística selecionada.

Assim, muitas vezes, a utilização de rótulos metadiscursivos pode servir aos propósitos argumentativos do enunciador. Francis (2003) afirma que, por serem os rótulos apresentados como dados, ou seja, como sinonímias dos segmentos rotulados, eles podem ser vistos como recursos que o falante/escritor seleciona para alcançar os objetivos de sua argumentação, indicando avaliações revestidas de um teor positivo ou negativo, de acordo com a situação discursiva.

Para Koch (2005), o rótulo metadiscursivo também pode ser um recurso que o produtor do enunciado utiliza-se para mostrar distanciamento, ou discórdia, em relação ao discurso rotulado, procedendo até mesmo à ironia ou à contestação. Isso se deve ao fato de a 
escolha da expressão metadiscursiva ser indicativa da opinião do enunciador, tanto sobre o procedimento lingüístico rotulado, quanto a respeito do próprio produtor desse enunciado e suas respectivas atitudes (sociais, lingüísticas etc).

De toda maneira, frisamos que a utilização de expressões nominais referenciais descrições, nominalizações, rotulações metafóricas, encapsulamentos - corresponde a uma escolha do produtor de textos, segundo o sentido que ele pretende imprimir ao discurso. Há no repertório lingüístico uma variedade de maneiras de apresentar e caracterizar o objeto de discurso; assim, toda escolha também desempenhará um papel argumentativo. Como afirma Koch (2001, p. 81): “Entre as possibilidades de atribuições a um referente, o sujeito faz escolhas significativas ou, até mesmo, estratégicas, tendo em vista seu projeto de dizer”.

Dentro desse quadro, há algumas funções gerais relacionadas às expressões nominais referenciais, tais como a cognitiva, a textual, a interativa e a semântica (Koch, 2006b). Todas elas cumprem significativo papel na construção do modelo textual e estão ligadas diretamente entre si. Entre as funções das expressões nominais referenciais, destacaremos alguns pontos que julgamos importantes para a elaboração de orientações argumentativas.

Primeiramente, na sua função cognitiva, as expressões nominais remetem a elementos precedentes ou sugeridos no co-texto, (re)ativando-os na memória do interlocutor. Além disso, trata-se da ativação de certas características do referente que leva o interlocutor a construir uma imagem, ou seja, a posicionar um olhar sobre o objeto referido. Essa ativação é relacionada aos conhecimentos julgados partilhados entre os participantes.

Na função textual, há a relação de coesão entre os recursos utilizados no nível microtextual. Já na macroestrutura textual, as expressões nominais sinalizam a mudança e o desvio de tópicos, servem para marcação de parágrafo, não necessariamente em seu sentido 
tipográfico, mas no sentido cognitivo do termo (Koch, 2006b), e sinalizam o estágio seguinte de uma argumentação.

Em sua função semântica, as expressões nominais desempenham importantíssimo papel, pois a escolha do nome/núcleo, dotado de carga avaliativa, será responsável diretamente pela efetivação de orientações argumentativas. Koch (2006b) afirma que, mesmo quando genérico, o nome expressará valores axiológicos, atuando ora como (re)ativador de referentes textuais, ora como operador explicativo do próprio discurso que explora um trecho antecedente (metadiscursividade).

Assim também, não poderíamos deixar de lembrar o papel do epíteto, ou dos modificadores qualificativos que podem apresentar valores positivos ou negativos ao auditório - recursos já evidenciados na Nova Retórica como primordiais na apresentação do referente dada a escolha argumentativa.

Ainda, cabe-nos ressaltar a posição de Blackledge (2005) que, ao estudar as estratégias discursivas nos discursos midiáticos, afirma que aquelas relacionadas à referenciação, geralmente, são metafóricas e metonímicas. Por esse ponto de vista, compreendemos que as categorias lingüísticas estabelecem entre si uma relação de continuidade a qual indicará, no co-texto, uma representação do objeto de discurso. Conseqüentemente, a imagem construída do referente textual poderá ser associada com outros elementos culturais e ideológicos, resultando em uma relação metafórica.

Além disso, a própria metáfora ou a expressão metafórica, interagindo com outras figuras, como a metonímia, ou com outras formulações lingüísticas, também exercerá significativo papel na (re)categorização do referente textual e na realização de avaliações que permitem a constituição de orientações argumentativas. 
Como a metáfora enquadra-se em um sistema amplo de estudo, tanto no âmbito textual/discursivo, quanto no argumentativo, explanaremos a seguir, mais detalhadamente, sobre essa figura e seu papel na argumentação.

\subsubsection{A metáfora ${ }^{23}$ como recurso argumentativo}

Desde a Antigüidade, percebeu-se o emprego de algumas expressões da linguagem verbal que se distanciavam do modo usual, ou seja, do seu padrão, e essas ocorrências foram incluídas também nos estudos retóricos, sendo denominadas figuras de retórica. Entre elas, a metáfora, intitulada tropo (transporte) e considerada a figura por excelência, era definida como a transferência da significação própria de uma palavra ou expressão para outro conteúdo semântico. Porém, é na Nova Retórica de Perelman e Olbrechts-Tyteca $(1958,2002)$ que as figuras de retórica desempenham um papel importante no processo argumentativo do discurso. Assim, elas deixam de ter uma função estética, ornamental e passam a situar-se no campo persuasivo/argumentativo dos estudos discursivos.

Na visão desses estudiosos, é na “função da teoria argumentativa da analogia que o papel da metáfora ficará mais claro” (1958, 2002, p. 453). Essa relação entre analogia e metáfora já era evidenciada na tradição dos filósofos, inclusive em Aristóteles, mas é na Nova Retórica que o conceito de analogia é aprofundado e a definição de metáfora, no que tange à argumentação, é apresentada como sendo uma analogia condensada, ou seja, considera-se a união entre o “elemento do tema” com o “elemento do foro“ (1958, 2002, p. 543). Assim sendo, a metáfora pode ser construída a partir de uma analogia ou até antes mesmo por meio desta.

\footnotetext{
${ }^{23}$ A metáfora tem sido analisada, entre outros, por Lakoff e Johnson (1980), na obra Metaphors we live by. Porém, não se conhece obra específica sobre metáfora e argumentação.
} 
Na utilização da metáfora, se as conclusões são direcionadas através do foro e das características recortadas deste, o recorte será associado ao tema, facilitando ao auditório perceber o objeto de discurso como é apresentado pelo orador, observando-se, assim, efeitos argumentativos. De acordo com os autores:

[...] não é surpreendente constatar, quando se examinam as argumentações por analogia, que, com freqüência, o autor não hesita, no curso de sua exposição, em servir-se de metáforas derivadas da analogia proposta, habituando assim o leitor a ver as coisas tais como ele as mostra. (Perelman e Olbrechts-Tyteca, 1958, 2002, p. 454)

Essa junção entre tema e foro pode-se efetuar de várias maneiras: por uma simples determinação, por um adjetivo, por um possessivo, por uma identificação e por palavras compostas, o que Perelman e Olbrechts-Tyteca denominam “sínteses expressivas” (1958, 2002, p. 457).

Ainda de acordo com esses estudiosos, embora todas as analogias, exceto as alegorias e as parábolas, possam se tornar metáforas, estas são mais ricas e significativas quando apresentadas desde o início da argumentação, porque essas formulações lingüísticas são tão expressivas que, ao interagirem com o auditório, podem resultar em interpretações diversas e, assim, em diferentes efeitos de sentido.

Os efeitos argumentativos dessas expressões podem enveredar por três direções. Ora a metáfora exprime um valor argumentativo de presença, levando aos interlocutores certos recortes do objeto, ora seu uso resulta numa comunhão entre orador e auditório ou, até mesmo, num aconselhamento, numa sugestão de escolhas. Esses efeitos podem coexistir, pois não surgem, necessariamente, isolados. Isso quer dizer que a metáfora, como figura de retórica e, assim, recurso argumentativo, produz efeitos de escolha, de comunhão e de presença $^{24}$, conforme o desenrolar do enunciado e da situação interacional.

\footnotetext{
${ }^{24}$ Escolha, comunhão e presença são termos utilizados por Perelman e Olbrechts-Tyteca $(1958,2002)$ para designar os possíveis efeitos argumentativos resultantes da utilização das figuras de retórica; entre elas, a metáfora.
} 
É importante salientar que a relação entre termos enunciada por meio da metáfora consiste num caráter vivo e variado que se encontra no campo da interação entre falantes, ou seja, é um recurso de criação, de invenção. Desse modo, como qualquer outro recurso da língua, a metáfora é uma escolha do falante de acordo com suas intenções e posições assumidas. O uso dessa figura pode colaborar, juntamente com outras formulações lingüísticas, no processo de construção do referente e, consecutivamente, direcionar o auditório a certas conclusões; ou seja, a metáfora ganha força argumentativa no contexto tido aqui em seu sentido amplo, lingüístico, situacional, cognitivo - pois leva à presença do interlocutor certas associações, ancoragens; em outras palavras, instaura-se um “laço” entre os termos introduzidos ou retomados, os conhecimentos lingüísticos e de mundo compartilhados e a situação interativa.

Isso evidencia que, apesar da metáfora ser polissêmica por natureza, ao ser inserida em determinada situação de interação, os efeitos de sentido dessa figura podem ser delimitados ou direcionados, de acordo com a organização do discursivo.

Perelman e Olbrechts-Tyteca $(1958,2002)$ ressaltam, ainda, que o lingüista, ao adotar a definição de metáfora defendida pelos autores, estabelecerá algumas distinções: preferirá chamar de catacrese, em vez de metáfora, o uso metafórico de um termo que permite designar aquilo para o que a língua não possui termo próprio (o pé da mesa, o braço da poltrona, a folha de papel); qualificará como expressões de uso metafórico aquelas que, de tanto serem utilizadas, já não são percebidas como figuras, mas consideradas formas habituais de se expressar mencionadas no dicionário (um pensamento claro, profundo ou sublime); reservará o nome de metáfora às metáforas originais. 


\subsubsection{As expressões de uso metafórico}

A concepção de Perelman e Olbrechts-Tyteca (1958, 2002), mencionada anteriormente, evidencia que uma metáfora pode desgastar-se, tornando-se não mais uma relação entre termos, mas um vocábulo de uso comum. Porém, esse estado pode ser transitório, pois, dependendo da maneira como é utilizada, uma expressão metafórica volta a ser atuante e se intitula novamente metáfora.

Nesse estado de uso comum, a metáfora é denominada “adormecida” ou “expressão de uso metafórico”. E se a observarmos como escolha argumentativa, perceberemos sua eficácia, em conjunto com outras estratégias, pois essas expressões adormecidas já estão enraizadas nas tradições culturais e discursivas de determinados contextos.

Ainda de acordo com Perelman e Olbrechts-Tyteca (1958, 2002), o reviver de uma metáfora adormecida, até mesmo dos mais comuns clichês, pode-se dar por vários recursos:

1. uso de analogias, de maneira explícita ou implícita;

2. uso de relações entre metáforas;

3. uso de expressões, ora no sentido literal, ora no sentido metafórico;

4. uso de uma metáfora adormecida juntamente com uma nova metáfora;

5. mudança do contexto habitual, ou seja, a expressão metafórica inserida numa situação inusitada, resultando em novos recortes para o objeto.

No último recurso, a mudança também pode ocorrer na relação de coexistência entre pessoa/grupo e seus atos, pois os sentidos podem ser orientados num processo de associação entre discurso e imagem do orador (como já discutimos à página 71) ou, especificamente, quanto ao que o auditório pensa do falante conforme seus atos, papéis sociais etc.

É importante mencionar que algumas expressões, como jargões e gírias, utilizadas por grupos específicos, podem parecer metafóricas para os que não pertencem ou não convivem 
com determinadas situações ou pessoas, porém, o uso contínuo dessas expressões, pelos membros de um grupo, apresenta-se como uma maneira habitual de se expressar. Essa “identidade de meio cultural” (Perelman e Olbrechts-Tyteca, 1958, 2002, p. 462) delimita o sentido metafórico de certas expressões.

Assinalamos, mais uma vez, que apresentação de uma metáfora ou uma expressão metafórica, juntamente com outras formulações lingüísticas presentes no enunciado e os conhecimentos partilhados entre os interactantes, possibilita que efeitos de sentido sejam direcionados e, assim, colabora com a efetivação de orientações argumentativas.

\subsubsection{A Metáfora e os efeitos argumentativos}

Dos pressupostos apresentados anteriormente, torna-se evidente que o orador, ao organizar seu discurso, trilha por caminhos não aleatórios, ou seja, ele faz uso das possibilidades da língua para construir sentidos, objetivando fazer o interlocutor criar uma imagem do objeto referido tal qual este é apresentado.

Os efeitos de sentido, portanto, são constituídos na maneira como o enunciado é organizado e nas formulações e reformulações lingüísticas escolhidas pelo orador. Além disso, é na interação entre sujeitos situados que será instaurado o jogo de opiniões e pontos de vista, em situação única.

Assim, esse efeito de sentido, constituído mutuamente nos enunciados por meio de seleções lingüísticas, é que direciona as orientações argumentativas. Nesse quadro, sendo a metáfora uma das possibilidades de escolha do locutor em relação ao sistema da língua, a força que ela traz à argumentação relaciona-se à maneira como ela é apresentada pelo orador e interpretada pelo auditório. 
Uma das possibilidades de interpretação da metáfora já foi mencionada neste capítulo, mas vale lembrar que é na situação discursiva que esse recurso colabora com a constituição de efeitos de sentido. Perelman e Olbrechts-Tyteca (1958, 2002, p. 211) citam que:

[...] o sentido e o alcance de um argumento isolado não pode, senão raramente, ser compreendidos sem ambigüidade; a análise de um elo da argumentação, fora do contexto e independentemente da situação em que se insere, apresenta inegáveis perigos.

Os autores evidenciam a importância de observarmos tanto a situação de interação, quanto a inter-relação dos recursos argumentativos utilizados num enunciado. Portanto, o valor argumentativo da metáfora é construído na interação com outras formulações lingüísticas ou, em outras palavras, no movimento constante de introdução ou retomada de referentes no texto (ativação, reativação e (de)ativação), pois ela cria uma maneira diferente de perceber o objeto em questão, enfatizando certos recortes e posições assumidas, ou mesmo, colaborando para a compreensão desses.

Além disso, se considerarmos todo o processo de interação, ressaltaremos também a importância dos elementos não-verbais e supra-segmentais (Marcuschi, 2001a, p.63) que interagem com os enunciados e, por vezes, colaboram na produção de sentidos. Destacamos, entre outros: olhares, gesticulações, risos, entonações, pausas etc.

Ainda, outro fator merece destaque no que tange à compreensão da metáfora. O papel da cognição é relevante nesse campo, principalmente se questionarmos como os conhecimentos de mundo, os entornos históricos, sociais e ideológicos estão organizados na nossa memória e como estes são fundamentais para a compreensão dos enunciados.

Muitas são as teorias e as concepções que permeiam essa área; nossa atenção nesta etapa do trabalho, entretanto, será voltada para os estudos de Lakoff e Johnson (1980), que citam a maneira como percebemos a realidade do nosso dia-a-dia e como nos relacionamos com as pessoas. De acordo com esses teóricos, é devido ao nosso sistema conceptual que 
podemos nos relacionar com o mundo e com as situações diárias. Este sistema é, em sua maioria, metafórico por natureza, ou seja, segundo os autores, as metáforas estruturam a maneira como percebemos, pensamos e agimos.

Em suma, percebemos que a metáfora está presente na linguagem verbal, mas não é própria desta. Apesar de se tornar evidente por meio da língua, ela está presente além das palavras, na organização discursiva, em nossa percepção de mundo e, conseqüentemente, está imbricada em nosso processo de interpretação.

\subsubsection{A Metáfora nos processos de referenciação}

Para ilustrarmos o papel da metáfora nos processos referenciais, como colaboradora de orientações argumentativas, passaremos a uma breve análise do enunciado desenvolvido por Denise Frossard, a respeito da seguinte pergunta lida por Paulo Markun (P.M.), às linhas 252259 do texto transcrito em anexo:

P.M. a minha pergunta é simples... se não está havendo hum:: ... ou se não esTAva havendo há bem pouco tempo atrás na CPI... essa tentativa de um lado de DESqualificação de certos depoentes e se outro lado de antecipação... da campanha eleitoral de dois mil e seis... e pergunto se não é SÉrio demais o assunto... para que a gente resvale para qualquer uma das atitudes... tanto... do lado da oposição de tentar POlitizar excessivamente o debate... como do lado do governo de tentar desqualificar... pessoas que têm feito denúncias GRA::vês... que emBOra...desqualificados alguns:: daqueles denunciantes... não... minimiza a questão e agora eu inVERto... a:: ordem e começo com César Borges

Nesse segmento, Paulo Markun (P.M.) questionou a atitude dos membros da CPI que, ao elaborarem suas perguntas, aproveitaram para desqualificar o depoente ou para fazerem propaganda das eleições presidenciais de 2006.

Vejamos a resposta, na íntegra, de Denise Frossard, atentando às partes destacadas: 
(9)

D.F. éh... eu vou fazer uma observação aqui Markun...ah:: aquela comissão é uma coisa no::va pra mim a CPI... né... e eu observo que ali... éh se transita entre NERvos partidários expostos... e não deveri::a ... porque na soleira da PORta da CPI... deveria ficar as COres partidárias... e adentrar aquele reCINto do plenário... as pessoas que vão investiGAR... porque ali não está a questão de governo... é essa a minha tese... ali está a questão de Esta::do... nós não estamos ali porque um cheFEte... dos Correios...foi...surpreendido com a mão... na boti::ja... nós estamos ali porque um depuTA::do fedeRAl que tinha a responsabiliDAde... de conduzir um partido como o senhor presidente... DI::sse que era assi::m...então quer dizer éh... eu sei que é difÍcil...mas tem que deixar as cores partidárias... porque...nós ali agimos como investigadores... e com poderes de juí::zes... portanto é I::sso que a democraCIa brasileira ainda nã/ aí a democracia brasileira ainda não amadureceu a este ponto... então é por isso que nós tivemos quarenta e nove CPIs no SeNA:do... de mil novecentos e quarenta e seis à mil novecentos e oitenta e Nove... das quais apenas dezeSSEte... chegaram a ser votadas ter o seu relatório votado... e diz o autor disso... que é um velho... hum um aposentado... um funcionário aposentado... ele diz QUAN::do oposição e goVERno se sentem...AMbos atingidos...há uma força uma contra a OUtra... e aí é o que se diz termina em pizza... é isso que nós temos que avanÇAR... como investigadores... fica aqui a minha/ o meu desafio

Depreendemos, no segmento anterior, que um referente é primeiramente reativado (resgatado da pergunta), às linhas 305-306: “aquela comissão é uma coisa nova pra mim”. Dessa maneira, Denise Frossard inicia seu turno apresentando o objeto de discurso por meio de uma expressão nominal iniciada por um pronome demonstrativo (aquela) e, posteriormente, faz uma nominalização “a CPI” (linha 306).

Ainda na linha 306, a juíza, utilizando-se de metáforas, faz uma descrição. Retomemos o segmento:

D.F. éh... eu vou fazer uma observação aqui Markun...ah:: aquela comissão é uma coisa no::va pra mim a CPI... né... e eu observo que ali... éh se transita entre NERvos partidários expostos... e não deveri::a ... porque na soleira da PORta da CPI... deveria ficar as COres partidárias [...]

A expressão “entre nervos partidários expostos” remete “aquela comissão”, a “CPI”; porém, observamos que se trata de uma metáfora, pois transporta sentidos, ou seja, nervos não transitam, muito menos, de maneira exposta. A enunciadora refere-se às posições assumidas pelos membros da CPI, seus papéis políticos que entram em conflito naquele cenário. Isso é 
evidenciado, no segmento lingüístico, por duas expressões nominais selecionadas posteriormente. A primeira é uma metáfora “as cores partidárias” (linha 306), repetida na linha 313:

[...] como o senhor presidente... DI::sse que era assi::m...então quer dizer éh... eu sei que é diFÍcil...mas tem que deixar as cores partidárias... porque...nós ali agimos como investigadores... e com poderes de juí::zes... portanto é I::sso que a democraCIa brasileira ainda nã/ aí a democracia brasileira ainda não amadureceu a este ponto [...]

Outra formulação que explicita e reforça o efeito de sentido trata-se da seleção "há uma força uma contra a outra” apresentada às linhas 319 e 320:

[...] e diz o autor disso... que é um velho... hum um aposentado... um funcionário aposentado... ele diz QUAN::do oposição e goVERno se sentem...AMbos atingidos...há uma força uma contra a OUtra... e aí é o que se diz termina em pizza... é isso que nós temos que avanÇAR... como investigadores... fica aqui a minha/ o meu desafio

O tipo de procedimento observado remete ao fato de que o falante, durante o desenvolvimento de seu discurso, vai tecendo uma linha de sentido. No exemplo apresentado, metáforas originais, juntamente com outras expressões literais, constituem e direcionam uma imagem do referente.

Podemos observar também, nesse exemplo, como um clichê pode tornar-se uma metáfora original e fortalecer, com mais expressividade, a tese apresentada (linha 310):

[...] nós não estamos ali porque um cheFEte... dos Correios...foi...surpreendido com a mão... na boti::ja... nós estamos ali porque um depuTA::do fedeRAl que tinha a responsabiliDAde... de conduzir um partido como o senhor presidente... DI::sse que era assi::m [...]

Lembremos que a expressão "boca na botija” já se transformou num clichê, é de uso comum, portanto, o seu sentido é compartilhado entre os participantes. Mas, Denise Frossard faz uma adaptação, ou seja, ao ser inserido no co-texto, esse clichê sofre uma modificação, a palavra “boca” é substituída por “mão”, adequando-se também ao contexto social e histórico e, até mesmo, ao supertópico do debate que é a corrupção. 
Assim, temos não só uma outra metáfora original utilizada no texto, como também, um significativo recurso argumentativo. Essa expressão, por já estar enraizada nos conhecimentos culturais e discursivos do auditório (pelo menos da maioria), é facilmente associada com o contexto político em que estão inseridos os participantes dessa interação.

Por outro lado, nesse mesmo enunciado, verificamos o uso de outro clichê "terminar em pizza”, porém, neste caso, não houve reformulação na expressão em si. Mas devemos salientar que ele foi situado num contexto e está interagindo com este. Vejamos a seguir (linha 320):

[...] um funcionário aposentado... ele diz QUAN::do oposição e goVERno se sentem...AMbos atingidos...há uma força uma contra a OUtra... e aí é o que se diz termina em pizza... é isso que nós temos que avanÇAR... como investigadores... fica aqui a minha/ o meu desafio

Assim, por ser uma expressão de uso metafórico, a sua força argumentativa colaborou para o estatuto de verdade do discurso, ao ser utilizado em uma conclusão.

\subsection{A importância da cognição situada nas orientações argumentativas}

Ao mencionarmos, anteriormente, a importância, na análise textual-discursiva, dos conhecimentos de língua e de mundo, dos valores culturais e históricos adquiridos pelos sujeitos e, assim também, da idéia não representacional da língua, consecutivamente, estávamos lançando um olhar nas relações sociocognitivas e no seu papel significativo na atividade linguageira.

Entretanto, por ser de extrema importância o papel da cognição situada na elaboração de enunciados e na sua organização interna, como também nas interpretações e na argumentação, apontaremos, nesta parte do trabalho, alguns conceitos da atividade cognitiva que colaboram para uma melhor compreensão das análises do texto, do discurso e da argumentação. 
Na vasta e crescente literatura sobre a questão da cognição, destacamos que, a partir da década 70, no campo da Psicologia Experimental, as investigações voltavam-se às atividades de processamento, considerando a cognição no âmbito do indivíduo. Essa perspectiva foi de extrema importância para o salto teórico das atuais abordagens sobre o tema.

Atualmente, fala-se de sociocognição interacional, por considerar as atividades de construção do conhecimento como um produto das relações sociais, isto é, há um dinamismo nos processos que dão origem à construção de sistemas conceptuais, tais como: metáforas, metonímias, anáforas, polissemias, indeterminações referenciais, entre outros. Tais estruturas possibilitam aos sujeitos entenderem os enunciados e as relações complexas neles existentes.

Nessa perspectiva, salientamos a noção de contexto sugerida por Kerbrat-Orecchioni (1996). De acordo com a autora, o contexto deixa de ter uma concepção “empírica” e passa a ser caracterizado como um conjunto de imagens mentais mobilizados na situação discursiva; é um modelo cognitivo constituído, pelo sujeito, no desenrolar de suas experiências.

Marcuschi (2002, p.47) também apresenta essa mesma noção de contexto, ressaltando que nossa própria experiência é uma percepção cognitiva e que a ação de discretização do mundo é de origem sociocognitiva, pois “a realidade empírica não tem um contorno imediatamente apreensível”.

Em relação aos discursos políticos e às práticas sociais que os regem, citamos Van Dijk (2004a) que também faz menção à definição de contexto como modelo mental. Segundo o autor:

Desde que situações políticas não se fazem simplesmente porque atores políticos falam de determinada maneira, nós novamente precisaremos de uma relação cognitiva entre a situação e a fala, ou texto, isto é, um modelo mental da situação política (Van Dijk, 1999, 2001, 2003). Os modelos mentais definem como os participantes experimentam, interpretam e representam os aspectos, para eles relevantes, da situação política. Esses específicos modelos mentais são chamados contextos. Em outras palavras, 
contextos são subjetivas definições sobre a situação comunicativa. Eles controlam todos os aspectos da produção discursiva e de sua compreensão 25 .

Dentro desse quadro teórico, podemos afirmar que a situação discursiva compreende uma inter-relação entre contextos. Nos debates políticos televisivos, os contextos, não necessariamente verbalizados, interagem entre si e se transformam após a interação. Isso também ocorrerá com o auditório em questão, pois seus contextos, em contato com a situação de debate, poderão ser modificados, possibilitando que o interlocutor chegue a certas conclusões. Isso determinará o alcance da argumentação (Aquino, 1997).

Os contextos também intervirão no processo de construção do referente textual. Apesar deste último se tornar possível por meio da língua em comum e dos conhecimentos partilhados, salientamos que esses fatores não são suficientes para sua concretização em específicas interações, pois devemos lembrar que há casos em que os objetos não são compartilhados entre os participantes, necessitando de uma construção interativa.

Nesse sentido, Koch (2006b, p.30) faz a seguinte afirmação:

Relações entre informação implícita e conhecimentos partilhados podem ser estabelecidas por meio de estratégias de "sinalização textual", por intermédio das quais o locutor, por ocasião do processamento textual, procurar levar o interlocutor a recorrer ao contexto sociocognitivo (situação comunicativa, scripts sociais, conhecimentos intertextuais e assim por diante). ${ }^{26}$

Assim, a (re)construção de objetos implicará elementos presentes na situação de interação e nos atos precedentes a esta, tais como: elementos lingüísticos dos enunciados, características não-verbais (ao tratar do texto falado, verifica-se a presença de pausas, de

\footnotetext{
25 Tradução nossa: Since such political situations do not simply 'cause' political actors to speak in such a way, we again need a cognitive interface between such a situation and talk or text, that is, a mental model of the political situation (Van Dijk, 1999, 2001, 2003). Such mental models define how participants experience, interpret and represent the for-them-relevant aspects of the political situation. These specific mental models are called contexts. In other words, contexts are subjective participant definitions of communicative situations. They control all aspects of discourse production and comprehension.
}

${ }^{26}$ Grifos da autora. 
entonações, de correções etc), relações entre os participantes, objetivos da interação, entre outros.

Todos esses elementos estarão, de certa maneira, interferindo na construção cognitiva da situação discursiva; as imagens mentais construídas - sobre o encontro, os referentes textuais, os tópicos em questão e o(s) outro(s) interactante(s) - serão baseadas na complexa relação entre as informações armazenadas pelos sujeitos, tanto aquelas já pré-concebidas, quanto aquelas adquiridas no momento da interação.

De maneira geral, o papel da cognição situada é de extrema importância com vistas à sua implicatura com a atividade linguageira-argumentativa nas práticas sociais. As ações humanas comportam essa dimensão discursiva-cognitiva-interacional, tornando-se essencial considerar toda sua conjuntura de implicações, ao posicionar nosso olhar no ato inerente às relações sociais: o de argumentar.

\subsection{A dinâmica na construção de referentes nos debates políticos televisivos: o jogo argumentativo}

Se a ação lingüística enquadra-se em uma dimensão cognitiva/interacional, a própria língua em si tem um caráter extremamente interativo. Em qualquer situação de troca, a interatividade faz-se presente na relação entre contextos; entretanto, é na modalidade falada da língua e, especificamente, nas interações face a face que o discurso explicita, em momento único, toda a dinâmica que o envolve.

Nos debates políticos televisivos, apesar de o sujeito elaborar seus enunciados conforme um projeto de dizer, suas falas são suscetíveis a receber controvérsias, fazendo que a situação torne-se palco de reformulações lingüísticas. Esse jogo discursivo comportará estratégias de referenciação pelas quais os participantes construirão objetos de discurso no desenvolvimento da situação discursiva. 
Marcuschi (2001b) afirma que a referenciação, numa interação face a face, é uma ação dinâmica, em que atividades inferenciais são realizadas na enunciação, isto é, ela é coconstruída na interação pela seleção lingüística e por elementos próprios da modalidade falada da língua. Sobre este ponto, ressaltamos as interrupções, as correções, as entonações, os olhares e os gestos, entre outros.

A afirmação desse estudioso corrobora a postulação de Mondada (2005a, 2005b) para quem, nas práticas orais, os processos de referenciação não se restringem à atividade discursiva, pois também se estendem às ações gestuais, aos movimentos no espaço, às orientações do olhar, ao contexto situacional etc.

Ainda sobre esse ponto, ressaltamos que, nas interações face a face diretas, é possível observar, de maneira privilegiada, a construção irônica do referente textual por parte dos falantes. Em outras palavras, os elementos extralingüísticos específicos da modalidade falada da língua possibilitam detectar se há distanciamento entre o que se fala (seleção lingüística referencial) e o tom, o olhar, a risada, o cotexto, o contexto situacional etc.

Por todos esses fatores, podemos afirmar que é no quadro da interação que os objetos de discurso são suscetíveis a transformações, pois são construídos dinamicamente pelos participantes de uma situação discursiva. Isso implica dizer que vários falantes podem elaborar e modificar os objetos referidos num processo de colaboração interacional, devido à diversidade de pontos de vista. Essa visão está de acordo com Mondada e Dubois (2003, p. 33), para quem: “Uma categoria lexical impõe um ponto de vista, um domínio semântico de referência, a concorrer com outras categorias sugeridas, e produzindo sentido a partir do contraste com as precedentes”.

Ainda de acordo com essas autoras, o processo de referenciação é desenvolvido no contraste entre duas denominações: uma descrição mais aproximada que consiste na primeira tentativa pode ser modificada posteriormente, recategorizando o objeto de discurso e 
construindo uma "representação cognitiva socialmente compartilhada com a realidade" (op. cit., p. 32).

Levando em conta essa afirmação, é possível dizer que os debates políticos televisivos são momentos em que os sentidos dos objetos de discurso estão sendo negociados. Enquanto um político enfatiza certas características por meio de diferentes estratégias nominais de referenciação, inserindo-os em categorias, o outro participante tenderá a recategorizá-los, construindo orientações argumentativas de acordo com o seu querer-dizer.

Se nessas situações houver mais de dois políticos debatendo, as negociações de sentido, pelas quais os referentes textuais são submetidos, alcançará ampla dimensão, ora de colaboração, ora de conflito. Nesse quadro, as reações lingüístico-argumentativas dependerão das posições assumidas pelos políticos que, unidos em torno de fatores ideológicos e sociais, construirão e (re)construirão referentes de maneira dinâmica dentro das conformidades do encontro produzido pela instância midiática, conforme observaremos pelas análises no capítulo IV. 


\section{CAPÍTULO IV}

Análise dos processos referenciais e de suas orientações argumentativas nos debates políticos 
Para procedermos à análise da (re) construção de objetos de discurso e suas orientações argumentativas a partir dos enunciados elaborados por políticos em um debate televisionado, proposta deste trabalho, consideramos necessário examinar algumas características relevantes do momento da enunciação, visto que estas influenciam no desenvolvimento da produção discursiva. De fato a seleção e a apresentação dos tópicos do debate, o cenário, o posicionamento da câmera, os segmentos de entrevistas, as charges são significativos para as análises.

A importância do exame da configuração do encontro leva em conta o apontamento feito por Charaudeau (2006a) sobre a organização dos debates televisivos, conforme indicamos à página 40 deste trabalho. Para o autor, esses programas são organizados com o intuito de provocar um acontecimento notável. Isso ocorre devido à encenação apresentada por meio da escolha dos participantes, em nosso caso, políticos, membros da CPMI dos Correios, divididos em dois grupos partidários, dos tópicos abordados, em nosso corpus, as denúncias de corrupção, os papéis institucionais dos membros da CPMI, os encaminhamentos das investigações, entre outros, e da mobilização de recursos verbais e não-verbais organizados de maneira a constituir efeitos de sentido e a influir no desenvolvimento do debate e, assim, na elaboração dos enunciados, conforme destacaremos pelas análises.

Por essa razão, procedemos à análise do corpus, examinando, primeiramente, alguns pontos significativos da abertura do debate, momento em que se estabelece o primeiro contato entre todos os participantes da interação - debatedores (políticos), mediador e narrador (instância enunciadora representada por vozes), telespectador - os tópicos discursivos abordados e os referentes (re)ativados. Em outras palavras, tanto os políticos, quanto o telespectador passam pela mediação do olhar perceptivo/interpretativo do lugar de produção (instância enunciadora), como aponta o seguinte quadro: 


\section{Exórdio do Drograma Roda Viva}

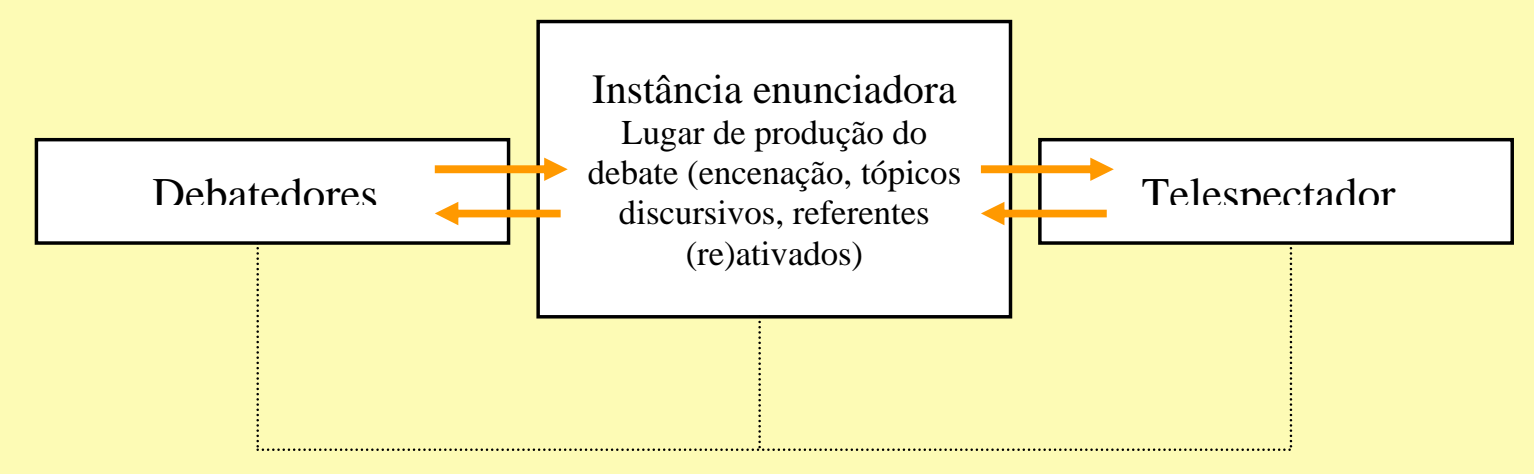

Perrencãn/Rernnherimentก

\subsection{A organização do programa: o exórdio}

Conforme discutimos às páginas 57-58 deste trabalho, os autores da Nova Retórica Perelman e Olbrechts-Tyteca $(1958,2002)$ - salientam que um dos momentos mais significativos da argumentação corresponde ao exórdio. É de fato a organização do discurso elemento importante na determinação dos objetivos da situação enunciativa, principalmente, no instante em que orador e auditório estabelecem o primeiro contato, como ocorre na abertura do programa Roda Viva ${ }^{1}$, em que este é organizado de maneira a despertar a atenção do telespectador, conforme observaremos nas análises.

Os estudiosos também afirmam que no exórdio é possível que se apresentem elementos que irão influenciar a situação discursiva, pois é nesse primeiro contato que o discurso poderá oferecer subsídios que orientarão o interlocutor a perceber a linha de sentido pretendida por seu enunciador. Como também a seleção das estratégias argumentativas direcionadas à referenciação - poderá colaborar na construção da imagem de quem enuncia, podendo enveredar pelo caminho da imparcialidade, da competência e do prestígio, todos esses almejados pela instância enunciadora, já que ela necessita de credibilidade para

\footnotetext{
${ }^{1}$ Na tese Conversação e conflito: um estudo das estratégias discursivas em interações polêmicas, Aquino (1997) já se referia à importância do exórdio no programa Roda Viva.
} 
organizar um debate e explanar sobre os tópicos selecionados. Com os políticos, esses objetivos não são diferentes.

Em relação a todos esses elementos sobre o exórdio, é interessante observarmos que o tanto o título do debate, “Crise política e corrupção 2005”2, quanto os supertópicos apresentados por Paulo Markun (P.M.), “a crise política”, “a corrupção” (linha 37), já direciona o olhar sobre algumas situações da política brasileira que vinham ocorrendo no ano em que o programa foi transmitido. Conforme indicamos à página 48 deste trabalho, os tópicos discursivos organizam em categorias os fatos observáveis no mundo, ou seja, a maneira como são referidos, por meio das escolhas lexicais, pode indicar pontos de vista e posições ideológicas - é o que ocorre com nosso corpus, em que se encaminha a discussão sobre política a partir de uma visão extremamente negativa. Além disso, “crise política”, “corrupção” e “2005” encerram valores que direcionaram os supertópicos e subtópicos do debate televisivo.

Ainda sobre esse ponto, se relacionarmos essa seleção lingüística com os estudos sobre corredores isotópicos apontados por Blikstein (1938, 2003), mencionados às páginas 80-81 deste trabalho (quadro 04), podemos afirmar que, na oposição entre retitude vs. tortuosidade, as palavras crise e corrupção enquadram-se na idéia de "torto", de desonestidade, de injustiça, imprimindo valores negativos aos referidos acontecimentos políticos. Segundo essa teoria, valores, como lealdade, ética, honestidade, que são vistos de maneira positiva, podem ser rompidos e surtir efeitos negativos às questões abordadas; é o que se observa em nosso corpus.

Depreendemos também que o cenário apresentado pela instância enunciadora propicia um direcionamento de sentido que se associa aos valores apresentados pelo título:

\footnotetext{
${ }^{2}$ O título “Crise política e corrupção 2005” apenas foi apresentado no DVD do debate sob análise.
} 


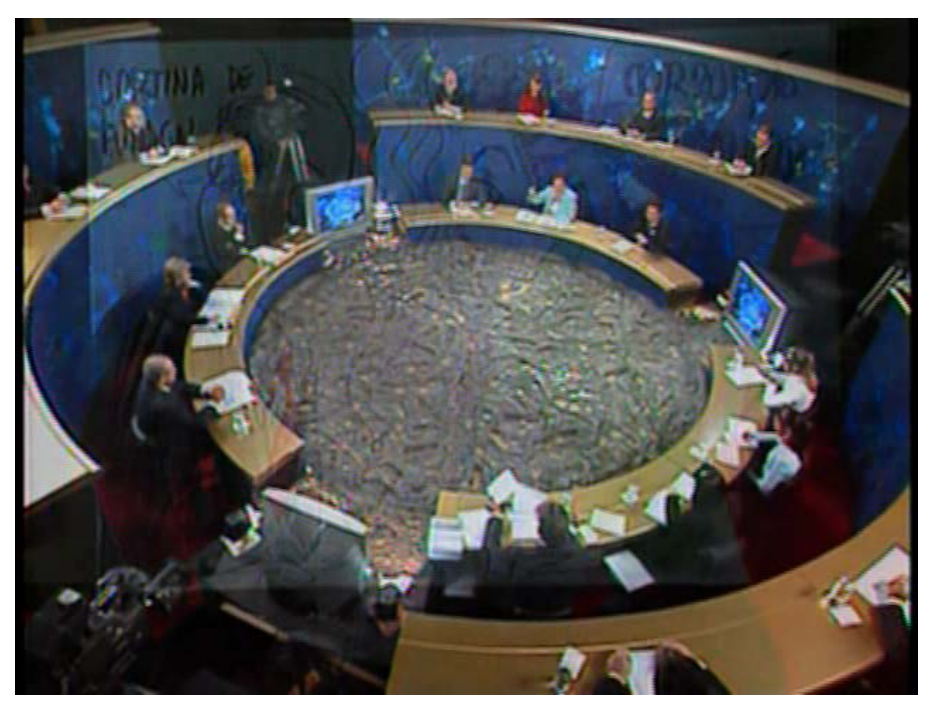

Fig. 05. No centro do cenário, “um mar de lama”.

Nesse cenário, o título do programa, “Crise política e Corrupção 2005”, é associado a um mar de lama (simulação observada no centro da figura 05). Mais uma vez, é possível detectar o direcionamento dado pela instância midiática às questões relacionadas à corrupção na política brasileira, encaminhando a um sentido extremamente negativo. De acordo com Charaudeau (2006a), conforme às páginas 36-37 deste trabalho, a mídia enuncia de maneira a evidenciar certas características do evento como ela o vê e, assim, a orientar efeitos de sentido, por meio da utilização de recursos verbais e não-verbais.

Também é possível observar esse efeito de sentido negativo na abertura do debate, em que há apresentação dos fatos a serem debatidos durante a interação, por meio de uma voz masculina que narra situações transcorridas na política, enquanto são exibidas imagens referentes a esses acontecimentos e segmentos de entrevistas gravadas, em que importantes personalidades políticas envolvidas em denúncias de corrupção comentam sobre o tópico. Podemos dizer que tanto o que se enuncia nesse exórdio do Roda Viva, quanto as gravações exibidas, apresentam o tópico sob um determinado prisma, podendo influir no desenvolvimento da interação. Isso pode ser observado no segmento enunciado pelo mediador do programa, Paulo Markun (P.M.), das linhas 1 a 8: 
P.M. boa noite... um funcionário público é flaGRAdo receben::do... o que parece uma proPIna de três mil reais... e o que de início... pareceu vamos dizer assim... um CAso coMUN:: de corrupção... acabou provocando uma crise política que saBEmos como começou... mas não sabemos como VAi terminar... que crise é essa? que desdobramentos ela pode ter? é o TEma do debate especial que fazemos hoje no Roda Viva... nas pegadas de uma TRIlha... que ao ser investiGAda... torna mais viSÍvel... a fase coRRUpta do Brasil... uma situação que desafia governo e INStituições a agir... e limPAR a lama que quase sempre marca as relações entre dinheiro e política

Nesse segmento, Paulo Markun (P.M.) apresenta o acontecimento político que será debatido durante o programa. Primeiramente, ele narra uma situação: “um funcionário público é flagrado recebendo o que parece uma propina de três mil reais” (linhas 1 e 2). Em seguida, comenta, modalizando como uma primeira avaliação: “o que de início pareceu, vamos dizer assim”, linha 2, e rotula a ação de dar e de receber propina como "um caso comum de corrupção” (linhas 2 e 3).

Ao modalizar, o enunciador nega a rotulação enunciada, ou seja, pressupõe-se que a situação narrada deixe de ser vista como algo “comum de corrupção”. Essa pressuposição é observada na continuidade da narração "acabou provocando uma crise política que sabemos como começou, mas não sabemos como vai terminar” (linhas 3 e 4), o que indica ser o caso incomum, mais complicado. Para retomar o segmento "uma crise política” de maneira a enfatizar a categoria apresentada, o mediador Paulo Markun (P.M.) seleciona a palavra “crise” e o demonstrativo “essa”, ao formular a pergunta “que crise é essa?” (linha 4).

Sobre esse procedimento, apontamos às páginas 87-88, conforme Koch (2005), que a utilização de expressões nominais também possibilita a (re) construção de segmentos precedentes ou subseqüentes do cotexto, de maneira a sumarizá-los sob um determinado rótulo, indicando o ponto de vista de quem enuncia.

Na seqüência, ao se referir à expressão “a fase corrupta do Brasil” (linhas 6 e 7), o mediador do programa (P.M.) procede a outra avaliação: “uma situação que desafia governo e 
instituição a agir e a limpar a lama que quase sempre marca as relações entre dinheiro e política” (linhas 7 e 8). Sobre isso, é importante observarmos que ao enunciar "desafia governo a agir”, o enunciador chama a atenção dos participantes do debate (os políticos) sobre a necessidade de ação deles para "limpar a lama”.

Sobre esse ponto, lembremos que a instância organizadora (o programa Roda Viva) também assume um papel significativo como representante da opinião pública a respeito dos tópicos discursivos abordados (atitude dos políticos em relação à corrupção, por exemplo). Essa representação é explícita durante o debate, como é possível observar às linhas 61-64, quando o mediador informa o número de telefone e o endereço eletrônico do programa para que haja participação da terceira parte, e também, no momento em que Paulo Markun (P.M.) seleciona e apresenta uma pergunta elaborada por um telespectador (linhas 400-404).

Ainda em relação ao exemplo (10), é relevante observar que essa expressão metafórica “limpar a lama” (linha 8), ao ser relacionada ao cenário do programa (mar de lama), que foi enfocado pela câmera no momento em que a avaliação foi enunciada, colabora com a efetivação de sentido construído em relação à situação política apresentada (“uma crise política”, “crise”, “corrupção”, “a fase corrupta do Brasil”). Dessa maneira, é possível constatar que elementos verbais e não-verbais entram em jogo novamente.

A seguir, às linhas 12-25, há alguns pontos significativos na maneira como o narrador (N) do programa Roda Viva apresenta os tópicos a serem abordados:

$\mathrm{N}$ o flagrante de suposta propina acaba envolvendo um deputado importante da base de apoio do governo... ameaçado ele se transforma em homem-BOMba e explode algo maiOR... das corrupções dos Correios às denúncias do mensaLÃO... o Congresso Nacional ferVEU... abriu conflito entre governo e oposição... e deixou o país perplexo com a nova onde de denúncias... barrada inicialmente por governistas... a CPI Mista dos Correios finalmente foi criada... e em menos de um mês de trabalho... ouviu quatro personagens importantes da crise... Maurício Marinho o homem dos três mil reais... Roberto Jefferson... que fez a denúncia de propina mensal de TRINta mil reais... a deputados aliados ao governo... Marcos Valério publicitário apontado por JEfferson como operador do mensalão... e Fernanda Karina Somaggio ex-secretária de 
Valério... testemunhando que o ex-padrão fazia grandes saques em bancos... com depoimentos em geral marcados por tumultos e exaltações... a semana que passou foi TENsa... e tudo volta a esquentar ainda mais aGOra... depois que Marcos Valério decidiu abrir o jogo e confessar... ter montado uma operação mi::lionária de crédito... para financiar o PT... a pedido de Delúbio Soares ((em seguida são incluídos trechos de uma entrevista televisiva em que Marcos Valério comenta sobre os empréstimos))

Observamos que a apresentação dos tópicos discursivos - as denúncias de corrupção, a instauração da CPMI etc - possibilita a ativação e a construção de alguns objetos de discurso, como ocorre com algumas personalidades envolvidas com o tópico abordado. Por meio da descrição “um deputado importante da base de apoio do governo” (linhas 11 e 12), o referente é instaurado de maneira a apresentar informações sobre ele, ou seja, refere-se a um “importante” deputado do "governo federal”. Posteriormente, é adicionado um rótulo a esse objeto de discurso com a utilização da expressão metafórica "homem-bomba” (linha 12), ou seja, ele “explode algo maior” e faz o Congresso Nacional “ferver”.

Sobre a utilização de rótulos metafóricos, apontamos à página 94 deste trabalho que essas expressões lingüísticas colaboram para o direcionamento argumentativo do enunciado, fortalecendo um ponto de vista, quando utilizadas juntamente com outras expressões “literais”, possibilitando ao auditório a percepção do objeto de discurso como é apresentado pelo enunciador, ou como seu sentido é direcionado.

É interessante observar que a instância enunciadora, ao apresentar o tópico e instaurar o referente acima mencionado, procede de maneira a informar o auditório (o telespectador) que “o deputado” era da “base do governo”. Esse procedimento possibilita uma associação entre o tópico em questão e o envolvimento do governo. Ainda, como o enunciado sob análise faz parte da apresentação do debate, a maneira como ele é elaborado colabora com a instauração de uma situação de confronto, já que foram convidadas personalidades políticas do partido do governo e da oposição. 
Sobre esse fato, vimos (páginas 70-71 deste trabalho) que todo discurso é produzido na relação instaurada entre sujeitos no momento da situação interativa e pela intencionalidade do encontro. Especificamente em relação aos debates políticos, também indicamos (página 70) que a produção discursiva de cada debatedor dependerá da tripla relação instaurada no encontro: o político e a audiência, pois esta é a quem o orador visa a convencer e/ou persuadir; o político e o partido que ele representa, já que a imagem de ambos sempre estará significativamente associada; o político e seus adversários, sendo que a relação entre estes pode ser instaurada no momento da interação, neste caso, no debate.

Assim, é interessante ressaltar que a maneira como a instância enunciadora apresenta o tópico discursivo e constrói os referentes textuais, além de trazer informações sobre determinado evento, também poderá influenciar no desenvolvimento do debate, em que os debatedores tenderão a desenvolver enunciados de acordo com sua posição social/ideológica e a de seu partido, ou grupo.

A instância enunciadora, por meio da voz de um narrador, mantém o procedimento de (re)ativar determinados objetos de discurso de maneira a apresentar informações sobre eles, como podemos observar em (12), às linhas 15-20:

$\mathrm{N}$ [...] a CPI Mista dos Correios finalmente foi criada... e em menos de um mês de trabalho... ouviu quatro personagens importantes da crise... Maurício Marinho o homem dos três mil reais... Roberto Jefferson... que fez a denúncia de propina mensal de TRINta mil reais... a deputados aliados ao governo... Marcos Valério publicitário apontado por JEfferson como operador do mensalão... e Fernanda Karina Somaggio ex-secretária de Valério... testemunhando que o ex-padrão fazia grandes saques em bancos...

Primeiramente, os objetos de discurso são apresentados por meio da expressão, com função catafórica, “quatro personagens importantes da crise”. Em seguida, cada referente é instaurado, ou retomado, como no caso de Roberto Jefferson que já havia sido mencionado, 
com a utilização de um nome próprio seguido de informações contextuais: "Maurício Marinho”, “o homem dos três mil reais” (linhas 16 e 17); “Roberto Jefferson”, “que fez a denúncia de propina mensal de trinta mil reais a deputados aliados do governo” (linhas 17 e 18); “Marcos Valério”, “publicitário apontado por Jefferson como operador do mensalão” (linhas 18 e 19); “Fernanda Karina Somaggio”, “ex-secretária de Valério testemunhando que o ex-patrão fazia saques em bancos” (linhas 19 e 20).

Como já mencionamos anteriormente, a maneira como a instância midiática apresenta os referentes textuais é ponto relevante para o encaminhamento do debate e para os procedimentos lingüísticos adotados por parte dos debatedores. No exemplo anterior (12), além de apresentar os objetos por meio de nomes próprios que produzem efeito de distanciamento e de exatidão dos fatos apontados, o segmento elaborado traz ao conhecimento, ou à lembrança do auditório, a atitude e o tipo de envolvimento nas denúncias de corrupção de cada depoente da CPMI dos Correios. Essa atitude possibilita o direcionamento interpretativo do enunciado e dos tópicos abordados durante o debate.

No segmento (13), linhas 37-39, Paulo Markun (P.M.) enuncia os participantes do debate:

P.M. PAra discutir a crise política os conflitos a disputa partiDÁria... e os possíveis rumos da investigação... reunimos neste debate no Roda Viva... seis integrantes da CPMI dos Correios... três que representam a oposição... e três que representam o partido do governo $[\ldots]$

Podemos afirmar que o exame do discurso de Paulo Markun (P.M.) aponta para a divisão partidária existente entre os debatedores: "três que representam a oposição”, "três que representam o partido do governo”. Assim, a maneira como se apresentam os participantes já é indicativa de que o debate transcorrerá em torno de pontos de vista distintos, antagônicos, constituindo-se, como atestam as teorias apresentadas no capítulo I deste trabalho, página 46, num momento de disputa argumentativa entre os políticos. 
Observamos também em (13) que, ao ressaltar o papel social dos políticos/debatedores, “seis integrantes da CPMI dos Correios” (linha 38), Paulo Markun (P.M.) os inclui na posição de autoridades, ou seja, a expressão lingüística selecionada aponta para políticos que possuem competência para explanar a respeito da CPI, das denúncias, das divisões partidárias etc. Observamos esse mesmo procedimento no segmento (14), linhas 3759:

P.M. [...] José Eduardo Cardozo deputado federal pelo PT paulista advogado... foi presidente da CÂmara municipal de São Paulo em dois mil e um... e presidiu a CPI da MÁfia do Comércio Ambulante da capital em noventa e cinco... e em noventa e nove presidiu a CPI... da MÁfia dos Fiscais... Ideli SalVAtti do PT primeira senadora de Santa Catarina... liderou a bancada do Partido dos Trabalhadores no Senado em dois mil e QUAtro... e é titular das Comissões de Educação... assuntos sociais... e Constituição e Justiça no Senado... e também pelo Partido dos Trabalhadores... o deputado Maurício Rands de PernamBUco... advogado... professor de direito constitucional... doutor pela Universidade de Oxford... e relator da reforma sindical... e é MEMbro da comissão que estuda a reforma política... e ex presidente da Comissão de Constituição e Justiça... pela oposição te::mos... o senador César BORges do PFL baiano... engenheiro... empresário... foi duas vezes governador da Bahia... relator do Estatuto do Desarmamento... é também autor da lei que permite a participação das FORças Armadas no combate ao CRIme organizado... também presente a deputada Denise FroSSArd do PPS do Rio de Janeiro... juÍza... ela ficou conhecida há quase dez anos... ao condenar toda a cúpula do crime organizado no Rio... é membro da Comissão de Constituição e Justiça da Câmara... e fundadora da ONG Transparência Brasil... dedicada a fiscalizar... e denunciar... casos de corrupção... e o deputado Gustado Fruet do PSDB Paraná... advogado_foi presidente da CPI do PROER... que investigou os escândalos financeiros... é membro do Conselho de Ética... e também da Comissão de Ciência e Tecnologia da Câmara federal... e foi relator da cassação do deputado André Luiz na Comissão de Ética...

No exemplo (14), os referentes textuais (os debatedores) são construídos de maneira a dar a conhecer ao telespectador (terceira parte) propriedades e fatos que contribuem para uma imagem de autoridade. Um exemplo disto é o segmento, linhas 39-42, que diz respeito à ativação e à construção do referente “José Eduardo Cardozo”, que ganha, posteriormente às linhas 39-42, outras categorias e propriedades: “deputado federal pelo PT paulista”, “advogado”, “presidente da Câmara Municipal de São Paulo”. 
Outro exemplo que evidencia a tentativa de construir uma imagem de autoridade refere-se à expressão “o deputado Maurício Rands de Pernambuco”, em que são apresentadas outras categorias: “advogado”, “professor de direito constitucional”, “doutor pela Universidade de Oxford”, “relator da reforma sindical”, “membro da comissão que estuda a reforma política”, “ex-presidente da Comissão de Constituição e Justiça”. Dessa maneira, é possível afirmar que o referente vai sendo construído ao longo do texto com o intuito de atender ao propósito do enunciador.

Sobre esse ponto, indicamos, à página 73 deste trabalho, que a sociedade possui instituições que organizam e possibilitam a interação entre falantes, como a mídia enquanto organizadora dos debates políticos televisivos. Além disso, há funções sociais ou, mais precisamente, papéis institucionais que autorizam o sujeito a explanar sobre certos tópicos.

Se retomarmos as teorias que atestam a respeito de como se apresenta a argumentação, às páginas 57-58 deste trabalho, podemos afirmar que, no exórdio do programa Roda Viva, momento em que o mediador atrai a atenção do telespectador, a maneira como foram apresentados os debatedores, com a exaltação de seus papéis institucionais, é indício de uma tentativa de, por um lado imprimir autoridade a esses sujeitos e, por outro, alcançar ou manter credibilidade à instância organizadora do debate. Por essa razão, podemos afirmar que há o intuito, por parte da mídia, de orientar argumentativamente seu auditório e, também, de salientar o papel dos debatedores como responsáveis pela investigação na Comissão Parlamentar de Inquéritos (CPI).

\subsection{A construção conjunta da imagem do presidente}

Em 4.1, observamos, por meio dos processos de referenciação ancorados em alguns recursos não-verbais, a maneira como foram apresentados os participantes do debate pela instância midiática, e como esta direcionou, num primeiro momento, os tópicos a serem 
abordados durante o programa. Isto porque consideramos estarem a ação e a reação discursivo-argumentativa dos sujeitos e os complexos sistemas de significação estritamente relacionados com as condições de produção em que eles estão inseridos.

Levando em conta toda a interação, atentamos aos segmentos em que os participantes (re) constroem a imagem do presidente. Esse procedimento deve-se ao fato de que o referente textual em questão foi (re)ativado de maneira recorrente durante o processo interacional.

Depreendemos, no texto transcrito, quarenta e uma ocorrências que dizem respeito à instauração e à (re) construção do referente por meio de expressões como: “o presidente”, vinte ocorrências, linhas 113, 114, 142, 143, 144, 150, 162, 173, 174 (por 2 vezes), 197, 588, 1091, 1126, 1131, 1142, 1166-1167, 1170, 1171, 1174, 1189; “o presidente da República”, onze ocorrências, linhas 99, 233, 235, 236, 709, 1093, 1109, 1119, 1185, 1186, 1208; “o presidente Lula”, sete ocorrências, linhas 127, 775, 1118, 1161, 1172-1173, 1218, 1209-1210; “Lula”, uma ocorrência, linha 148; “Senhor Lula”, uma ocorrência, linha 312; “O senhor presidente”, uma ocorrência, linha 312.

Em relação aos grupos políticos, essas escolhas lingüísticas foram utilizadas da seguinte maneira:

\begin{tabular}{|l|l|l|}
\hline Expressão nominal & Grupo do governo & Grupo da oposição \\
\hline O presidente da República & 2 ocorrências & 9 ocorrências \\
\hline O presidente Lula & 6 ocorrências & 1 ocorrência \\
\hline O presidente & 10 ocorrências & 10 ocorrências \\
\hline Lula & & 1 ocorrência \\
\hline Senhor Lula & & 1 ocorrência \\
\hline O senhor presidente & & 1 ocorrência \\
\hline
\end{tabular}


A observação do quadro comparativo pode indicar preferências de expressões por parte de cada grupo, principalmente a formulação “presidente da República” que aparece 9 vezes nos enunciados do grupo da oposição contra apenas 2 vezes nos dos governistas. No caso da expressão “presidente Lula”, a preferência fica por parte dos petistas.

Podemos também afirmar que entre os modificadores “da República” e “Lula” em relação ao presidente, ambos responsáveis pela especificação do objeto de discurso mencionado, o último apresenta efeito de aproximação entre orador/referente, pois a seleção privilegia o nome, enquanto o primeiro ressalta e especifica somente a função, sem nomear. Isto leva à observação do jogo aproximação/distanciamento (indicadas no quadro 06) entre os próprios partidos políticos.

Entre as quarenta e uma expressões, selecionamos as mais significativas para serem efetuadas as análises nas páginas a seguir, principalmente as que trazem, em seu cotexto, acréscimos de informações, ou ajustes por meio de descrições, de encapsulamentos e de rótulos, que colaboram para as orientações argumentativas.

\subsubsection{A construção pelo grupo da oposição}

Como indicamos à página 83 deste trabalho, é na organização e na progressão textual que os objetos de discurso são ajustados ou reforçados pelos falantes, efetivando-se, assim, uma linha referencial orientadora de sentido. Isso é possível detectar na maneira como os políticos da oposição constroem a imagem do presidente, atribuindo-lhe uma imagem negativa.

Um exemplo disso refere-se aos segmentos (15) e (16), linhas 98-100 e 112-117 respectivamente, em que César Borges (C.B.), do PFL, comenta sobre a entrevista televisiva com “o presidente da República” transmitida dois dias antes do debate sob análise: 
(15)

C.B. olha as:: declarações que nós assistimos este final de semana parece ser algo que está concatenado... de um lado... o presidente da República...coloca sobre:....o financiamento de campanha um problema [...]

Neste exemplo, César Borges (C.B.), ao responder a pergunta de Paulo Markun (P.M.) sobre as declarações do presidente, de Marcos Valério e de Delúbio Soares, reativa um objeto de discurso por meio da expressão “o presidente da República”. Posteriormente, ao retomar esse referente textual, no desenrolar de seu turno (linhas 112-117), ele faz outra seleção lingüística.

C.B. [...] então nós não podemos imagiNAr... que através de escaPISmo...ou divergioNISmo... a população brasileira não vai identificar os culPA::dos...DEste momento que conquistaram esse cenário aqui tão bem representado um verdadeiro mar de LA::ma... a população está assistindo perplexa... essa situação... e quer averiguações profundas... eu acho que o presidente que declarou que não quer PEdra sobre pedra...o presidente que declarou... que quer efetivamente até cortar na própria CARne... ele tem que orientar até sua banCA::da na Comissão Parlamentar Mista de Inquéritos... para que tenha Essa disponibilidade... essa disposição...de esclarecer efetivamente todos os fatos... é isso que deseja... a opinião pública brasileira e não te/ ter ( ) e cortina de fumaça

Os elementos destacados em (16) permitem observar que, ao retomar o referente, o senador, utilizando-se de uma descrição, apresenta algumas informações sobre as afirmações do presidente. Essas expressões possibilitam orientação argumentativa que sustenta a tese que o orador quer defender: a de que os discursos do presidente, do Marcos Valério e do Delúbio Soares não são verdadeiros ou, melhor, são "cortinas de fumaça”; como também são questionadas as ações do presidente, ou a inadequação destas.

Sobre a utilização de descrições (páginas 86-87, capítulo III), podemos afirmar que, no exemplo anterior, tornou-se evidente a presentificação de informações possivelmente julgadas 
desconhecidas por parte do auditório. Quando o senador informa, ao referir-se, ele também oferece subsídios para que o interlocutor acompanhe seu ponto de vista.

Em relação às descrições utilizadas pelo senador César Borges (C.B.) - “o presidente que declarou que não quer PEdra sobre pedra...o presidente que declarou... que quer efetivamente até cortar na própria CARne” - , verificamos uma ocorrência semelhante em um dos enunciados de Gustavo Fruet (G.F.), da oposição- às linhas 1107-1109, indicados a seguir:

G.F. [...] é o tempo que irá julgar cada um de nós... nós seremos julgados pelos resultados da CPI... mas em cima de um caso concreto... a reforma política... o financiamento público... pode ser uma conseqüência de melhora... mas nós estamos investigando uma denúncia... dentro da base aliAda... DO governo... envolvendo lideranças... proFUNdamente ligadas... ao presidente da República... que prometeu fazer diferente $[\ldots]$

O vereador reporta-se às denúncias de corrupção que envolvem membros ou alguns líderes do Partido dos Trabalhadores, salientando a necessidade de investigação tanto por parte da oposição, quanto do governo. Ao desenvolver esse tópico, Gustavo Fruet (G.F.) traz à lembrança do telespectador uma promessa do presidente da República, em tempos eleitorais, com a utilização da descrição “o presidente da República que prometeu fazer diferente”.

Observamos, nesse procedimento, que Gustavo Fruet (G.F.) faz uma cobrança a respeito da promessa do presidente, ou seja, apresenta indícios de que o discurso de Lula no momento da eleição não condiz com suas atitudes, já que as denúncias incluem membros de seu partido.

Esse quadro nos faz lembrar do conceito de "esquemas específicos de grupo" apresentado por Van Dijk (2003), conforme discutimos às páginas 50-51 deste trabalho, em que é estabelecida uma relação entre o “eu”, a voz de um grupo, e o “outro”, isto é, há uma 
inter-relação entre o grupo e seus membros ou, nesse caso em (17), os políticos e seu partido político ou filiado. Em outras palavras, o presidente, por ser do mesmo partido de alguns políticos envolvidos em denúncias, correlaciona-se, de certa maneira, a eles e a suas atitudes.

Sobre a orientação argumentativa resultante dessa relação, retomemos Perelman e Olbrechts-Tyteca $(1958,2002)$ que afirmam ser a coexistência entre a pessoa e o grupo um fator importante à argumentação, pois a imagem construída de um, negativa ou positiva, pode se manifestar no outro.

Na mesma direção de (17), César Borges (C.B.), do PFL, às linhas 185-187, ao optar por uma expressão nominal com função catafórica para retomar o objeto de discurso “o presidente da República”, inclui o referente textual no quadro das denúncias de corrupção:

C.B. mas eu acho que quem... efetivamente... é o maior responsável é o presidente da República... nada seria feito sem a sua autorização... inclusive com a relação a saber ou não do mensalão...

Depreendemos no segmento anterior que a expressão “o maior responsável” refere-se ao objeto de discurso “o presidente da República” de maneira a incluí-lo como participante das ações ilícitas colocadas em questão. Ainda, apesar de o enunciado ser elaborado por meio de uma elipse (o maior responsável “pela corrupção deste governo”), seu direcionamento de sentido é explícito, ou seja, a seleção lingüística de César Borges (C.B.) orienta argumentativamente, na tentativa de desqualificar o referente textual (presidente) que é apontado como “responsável”.

Essa orientação argumentativa de (18) permanece em (19), linhas 1188-1190, em que César Borges (C.B.), ao mencionar que Roberto Jefferson havia dito ao presidente sobre o mensalão, e que nenhuma providência havia sido tomada por parte de Lula, o orador (C.B.) 
utiliza encapsulamento (“isso”) e avalia por meio da expressão nominal indefinida "um crime de responsabilidade”, como é possível detectar nos segmentos destacados:

C.B. [...] o Roberto Jefferson disse que falou duas vezes com ele... apenas disseram que não foram duas... foi uma vez... mas falou... e nenhu::ma providência foi tomada então isso constitui-se um crime... de responsabilidade $[. .$.

Podemos observar, em (19), a avaliação atribuída à atitude do presidente por parte do senador César Borges (C.B.), em que este transfere novamente para Lula a responsabilidade sobre a corrupção; entretanto, dessa vez, inclui essa ação na categoria de “crime”, imprimindo outros valores pejorativos ao fato apresentado.

\subsubsection{A construção pelo grupo do governo}

Até o momento, depreendemos da transcrição do texto, alguns processos referenciais utilizados pelo grupo da oposição. Vimos que em todos os exemplos, a imagem do presidente é construída dinamicamente de maneira negativa, por meio de apontamentos que ora questionam a atitude tomada de Lula, ou a falta dela, ora o inclui como responsável por um “crime” a respeito da corrupção.

Salientamos que há segmentos em que os políticos do partido do governo também constroem o referente “o presidente da República”, “o presidente”, “o presidente Lula”, porém, atribuindo avaliações e qualificações que encaminham para efeitos de sentido numa direção diversa daquela apresentada pela oposição. É esperado, então, que eles valorizem o representante máximo de seu partido.

Sobre a atitude de Lula, destacamos o turno de José Eduardo Cardozo (J.E.C.), linhas 1125-1128. É possível observar que: 
J.E.C. eu tenho CERteza que o presidente está preserVAdo... rigorosamente preservado desse escândalo e tem dados sinais muito CLAros na LInha é:: disso como disse “invesTIR em mim... vamos cortar na própria CARne” que é o coMANdo que ele tem dado a nós [...]

o enunciador seleciona um rótulo metadiscursivo que avalia a atividade linguageira de Lula como: “o comando”. Isso corrobora a indicação de Francis (2003), página 89 deste trabalho, quantos aos rótulos - por serem apresentados como dados, tornam-se recursos que servem aos objetivos de um argumento, assumindo sentidos negativos ou positivos no discurso, conforme o contexto e o cotexto em que se encontram.

No caso do segmento em questão, podemos dizer que a rotulação avaliativa “comando” encerra valor positivo ao discurso rotulado, pois “comandar” é a função de um líder, como o é um presidente. Essa orientação argumentativa ganha força por se apresentar após o discurso direto “invesTIR em mim... vamos cortar na própria CARne” que constrói a imagem de um presidente capaz de sacrificar até seu próprio grupo, em nome da justiça.

Além disso, importa-nos salientar que a expressão metafórica (“cortar na própria CARne”) foi selecionada pelo presidente da República em alguns de seus discursos transmitidos pela mídia, na época em que o debate sob análise foi organizado. Dessa maneira, em (20), José Eduardo Cardozo (J.E.C.) traz à lembrança do auditório o posicionamento de Lula a respeito das denúncias de corrupção que envolviam alguns petistas.

Por meio desse recurso de intertextualidade, o deputado ainda se utiliza de um elemento próprio da modalidade falada da língua: a ênfase na palavra “CARne”. Em relação a esse procedimento, reportemo-nos à afirmação de Van Dijk (2003), página 48 deste trabalho, sobre as posições ideológicas que podem aparecer de maneira implícita nos discursos, como o caso das entonações silábicas. 
Essa organização discursiva de José Eduardo Cardozo (J.E.C.) ressalta o jogo argumentativo presente nas práticas discursivas entre políticos, pois é importante salientar que, anteriormente ao seu enunciado, às linhas 1091-1098, o vereador Gustavo Fruet (G.F.), da oposição, fizera o seguinte comentário sobre a falta de liderança do presidente:

G.F. [...] o presidente hoje está na seguinte situação... de um Lado... se ele sabia muito grave... e eu lembro que ex-ministro José Dirceu antes de sair... de forma TAxativa afirmou... "tudo que fazia Era do conhecimento do presidente da República" se do outro lado... ele não sabia... também é muito grave... porque de um presidente se espera algo mais do que ficar indignado e chorar... de um presidente se espera liderança... para que num momento de crise tomar atitude... nem que se signifique tomar decisões na própria carne o Roberto Jefferson foi responsável... pela maior reforma ministerial... DEsse governo... o presidente poderia ter se antecipado [...]

Às linhas 1160-1168, segmento (22), no turno de Ideli Salvatti, do PT, volta a ocorrer o que mencionamos sobre a tentativa de avaliar positivamente as ações do presidente em (20). Isso, de certo modo, evidencia o ponto de vista em comum dos membros do partido do governo em relação aos da oposição, como se observa em:

I.S. [...] e foi por isso que o presidente Lula... adotou uma série de medidas e orientações e:: ah:: orientações muito CLAras ah:: no seu governo... na estrutura de governo... através do Ministério da Justiça... através das ações da Polícia Federal... através da Controladoria Geral da União através do Ministério da Justiça... através das ações da Polícia Federal... através da Controladoria Geral da União... para que nós pudéssemos ter uma série de:: operações de ações... e de modificações... inclusive legislativas que partiram né da da iniciativa do próprio governo no sentido de combater... e de reestruturar a máquina pública... na lógica de fazer o combate a corrupção... por isso que o presidente que tem dado uma demonstração clara... e as pessoas enxergam isso as pessoas vêem isso... as pessoas têm a VIsibilidade do combate à corrupção $[\ldots]$

Ideli Salvatti desenvolve um discurso que salienta as várias ações do presidente com o intuito de “combater” - como em (20) - a corrupção. Posteriormente, por meio da descrição 
“o presidente que tem dado uma demonstração clara”, a oradora (I.S.) apresenta orientação argumentativa em favor de Lula, sustentada pela voz da opinião pública (“as pessoas”, repetida por três vezes, linhas 1167-1168). Neste caso, observamos que a inclusão da terceira parte é significativa para criar o efeito de verdade da tese apresentada.

Conforme discutimos à página 69, a respeito dos imaginários de verdade de Charaudeau (2005), observamos que Ideli Salvatti (I.S.), em (22), utiliza o imaginário da soberania popular, resultando num efeito em que a voz da população é soberana, e seu julgamento e sua opinião são respeitados.

Incluímos a essa observação, os conceitos da retórica aristotélica e da Nova Retórica de Perelman e Olbrechts-Tyteca (1958, 2002), páginas 56-59 deste trabalho, sobre a importância de adequar o discurso a um auditório, de maneira a aproximá-lo e a conseguir um acordo, como o faz Ideli Salvatti no segmento (22).

Ocorre também esse tipo de avaliação, às linhas 1170-1173, no segmento (23), em que Ideli Salvatti apresenta o mesmo direcionamento argumentativo do exemplo (22):

I.S. [...] a população não enxerga... o envolvimento do presidente a população é continua confiante no presidente... a população... ah quando é perguntada inclusive qual é a pessoa mais ah preparada para combater a corrupção? como apareceu agora na ( CNT Sensius) aparece o presidente Lula [...]

Em (23), Ideli Salvatti utiliza a pergunta “Qual é a pessoa mais preparada para combater a corrupção?” (linhas 1171-1172), para designar “o presidente Lula” (linhas 11721173). Mais uma vez, a orientação argumentativa ganha força, por estar inserida como afirmação da própria população. Ela recorre à opinião da população e isto nos remete à teoria de Charaudeau (2006a) sobre o imaginário de verdade da soberania popular, como dissemos anteriormente, nesta página. 


\subsection{A dinâmica na “fabricação” dos acusados de corrupção}

Durante o debate, os tópicos discursivos a respeito das denúncias de corrupção, dos papéis institucionais dos membros da CPMI, dos encaminhamentos das investigações, entre outros, possibilitaram a ativação e a constante (re) construção de objetos de discurso que, de modo geral, enquadram-se entre “aqueles acusados de corrupção política”.

Nesta parte da análise, esses referentes textuais serão nosso foco de atenção, especificamente aqueles que foram construídos de maneira dinâmica, entre os participantes do debate, e possibilitaram orientar argumentativamente a terceira parte (o telespectador).

Um exemplo disso ocorre às linhas 980-992 do texto transcrito. Neste segmento, José Eduardo Cardozo, Ideli Salvatti e César Borges discutem, com sobreposição de vozes, a respeito da corrupção nos partidos políticos. Se, por um lado, o senador do PFL apresenta informações que incluem o Partido dos Trabalhadores nessas ações ilícitas, por outro, os dois políticos petistas argumentam que a corrupção vem antes do governo do PT, inclusive encontra-se também no do PFL, como podemos observar no segmento (24):

$[\ldots]$

J.E.C.

o senhor o senhor conheceu o governo Collor não? ... o o seu partido não apoiava o Collor?

C.B.

J.E.C. não (não) apoiava

não apoiava o Collor?... o presidente do seu parTIdo Jorge Bornhausen era C.B. [ miNIStro do Collor não era?

( ) veja tomou emprestado de uma empresa tomou emprestado de uma empresa que tinha contrato

I.S.

C.B.

chefe de governo

$$
\text { [ }
$$


com o Correio ( ) dado como garantia repasso de recurso público para pagar os quarenta milhões que já está pago o PT não deve um tostão mais já está pago já está pago o empréstimo

J.E.C.

\section{o presidente do seu parTIdo Jorge Bornhausen foi} miNIStro do governo COllor o senhor não viveu esse período? o o senhor o senhor não I.S. lembra... do governo Collor? do esquema PC Farias?

esqueceu amnésia... amnésia (total)

Podemos observar ainda, no segmento anterior, que o referente textual “o presidente do seu partido Jorge Bornhausen” ganha informações, como: “ministro do Collor”, “ministro do Governo Collor”, “chefe de governo”. As formulações escolhidas por José Eduardo Cardozo e Ideli Salvatti, ambos do PT, podem indicar traços pejorativos ao referente e ao partido de César Borges, pois apresentam associação ao ex-presidente Collor e ao seu governo, trazendo à lembrança que este também foi envolvido em denúncias de corrupção.

Dessa maneira, podemos afirmar que as expressões nominais com função referencial escolhidas por José Eduardo Cardozo e por Ideli Salvatti demarcam o ponto de vista de ambos e permitem orientação de sentido, por meio de seus valores argumentativos. Conforme indicamos à página 90 deste trabalho, Koch (2001) afirma que os sujeitos fazem escolhas significativas ou, até mesmo, estratégicas, tendo em vista seu projeto de dizer. É o que ocorre.

Ainda sobre o exemplo (24), observamos que, enquanto os dois petistas constroem dinamicamente o referente “o presidente Jorge Bornhausen”, o senador permanece com suas acusações sobre o PT e nega o apoio do seu partido ao governo Collor.

Sobre o procedimento de César Borges (C.B.), Ideli Salvatti (I.S.) avalia como “amnésia”. Apesar da câmera não focalizar a enunciadora, sua avaliação pode ser tomada como um procedimento irônico, se relacionada ao cotexto e à situação de produção, o que se coaduna com o apontamento feito por Mondada (2005a, 2005b) e Mondada e Dubois (2003), 
indicado às páginas 105-106 deste trabalho, sobre a sensibilidade dos objetos de discurso em relação ao contexto, resultando numa instabilidade de sentido.

\subsubsection{Os petistas}

Em seguida, passemos à analise das expressões nominais referenciais utilizadas pelos políticos para designar alguns petistas envolvidos em denúncias de corrupção, na época em que o debate foi produzido.

Vejamos o enunciado da juíza Denise Frossard, do PPS, às linhas 1149-1155 do texto transcrito em anexo:

D.F. [...] eu se fosse do PT e teria muita honra... tenho grandes amigos lá estão aqui o Rands... o Cardoso conheci a Deli agora... mas:....eu SINto que vários amigos meus foram angaNAdos... enganados por uma cúpula... que capturou...o es-TA-do...brasi-LEI-ro...numa organização crimiNO::sa sim... e o fim era capturar o Estado... e por isso uSAram o crime de corrupção... inclusive a lavagem de dinheiro... lamen::to mas não imPULto ao PT... eu impulto a uma CÚpula... igual aquela que eu julguei...há treze anos atrás

Constatamos, em (25), o efeito de sentido progressivo na construção da referência, que se constitui no desenvolvimento da produção discursiva de Denise Frossard. Nesse exemplo, a oradora faz seleção e adequação lingüística para construir o referente textual conforme seu projeto de fala e a situação de produção. Sobre isso, retomemos as teorias apresentadas no capítulo III deste trabalho (páginas 104, 105 e 106) que atestam a respeito das construções discursivas orais e suas especificidades. Na modalidade falada da língua, o locutor, apesar do imediatismo do encontro, faz seleções lingüísticas que podem ser ajustadas, ou adaptadas. São tentativas que buscam o direcionamento argumentativo pretendido. 
Ao selecionar "uma cúpula que capturou o estado brasileiro numa organização criminosa” (linha 1151-1152), a juíza, posteriormente, estabelece comparação, por meio da descrição “uma cúpula igual àquela que julguei há treze anos...” (1154-1155), reportando-se aos políticos do governo Collor. Dessa maneira, a oradora apresenta mais uma avaliação, ativando um endereço cognitivo que poderá ser associado ao objeto de discurso em questão. Se a informação apresentada for do conhecimento do auditório, o referente textual receberá uma avaliação negativa, de desprestigio, de desonestidade.

Às linhas 1180-1185 do texto transcrito em anexo, volta a ocorrer, por parte do senador César Borges (C.B.), o que mencionamos anteriormente, no turno de Denise Frossard (D.F.), exemplo (25), sobre a tentativa de desqualificar o referente textual. Isso, de certo modo, enfatiza que ambos partem do mesmo ponto de vista. Vejamos:

C.B. Markun eu acho que:: o PT cometeu um grave equívoco... quando como partido... procurou aparelhar o governo... com os seus correligionários sem olhar para 0 mérito... nem a qualidade... daqueles que assumiriam a responsabilidade de governar 0 país... indicar apenas se tinha sido sindicalis::ta há tantos anos... se tinha sido mais ou menos fiel ao governo... com isso fizeram o aparelhamento que ficou extremamente difícil... o controle por parte do presidente da República [...]

César Borges (C.B.), ao referir-se a alguns membros do PT que obtiveram cargos no governo, utiliza a nominalização “os seus correligionários” (linha 1181). Em seguida, são incluídas características desse objeto: “sindicalistas há tantos anos” (linha 1183), “mais ou menos fiel ao governo” (linha 1183). Nesse procedimento, a imagem do referente vai-se constituindo de acordo com os recortes evidenciados. As expressões escolhidas são dotadas de valor, pois remetem a categorias avaliativas. Isso se efetiva com a expressão "mais ou menos”, em que o orador coloca em questão o valor “fidelidade”, sendo que este remete a outros valores, como: honestidade, ética etc. 
Perelman e Olbrechts-Tyteca (1958, 2002), conforme indicamos às páginas 60-61 deste trabalho, observam que alguns valores são significativos para os efeitos argumentativos, sendo que, por vezes, são utilizados com o intuito de motivar determinados auditórios a certas escolhas. O valor “fidelidade” evocado pelo orador, por já estar enraizado, de maneira positiva, nas tradições culturais da sociedade, servirá de sugestão, como também de complementação, na construção da imagem do objeto referido.

Ainda em (26), importa-nos ressaltar que o referente textual construído por César Borges (C.B.) às linhas 1181 e 1183 - “os seus correligionários”, “sindicalista”, “mais ou menos fiel ao governo” - não corresponde ao mesmo de Denise Frossard (D.F.) em (25) “uma cúpula que capturou o estado brasileiro - ou seja, não há relação correferencial ; entretanto, quando o senador refere-se aos “correligionários de Lula”, podemos inferir que neste grupo de “correligionários” também há menção áqueles ligados ao Partido dos Trabalhadores, envolvidos em denúncias de corrupção. Como conseqüência disso, as características selecionadas do referente em questão, em (26), podem também ser associadas aos petistas, cujas possíveis ações ilícitas estavam sendo investigadas.

Podemos observar que César Borges (C.B.) mantém a tentativa de desqualificar o objeto de discurso. Desta vez, o orador inclui o referente na categoria “culpado” (linhas 109113):

C.B. [...] então nós não podemos imagiNAr... que através de escaPISmo...ou divergioNISmo... a população brasileira não vai identificar os culPA::dos...DEste momento que conquistaram esse cenário aqui tão bem representado um verdadeiro mar de LA::ma... a população está assistindo perplexa... essa situação... e quer averiguações profundas [...] 
Sobre o exemplo (27), é preciso assinalar que, nesse momento do debate, o senador questiona sobre as declarações do presidente da República, de Marcos Valério e de Delúbio Soares (C.B.), apontando para o fato de que eles direcionam o problema da crise política à questão do financiamento de campanha e à recorrência dessa prática no campo político. O orador César Borges, negando essa posição e avaliando-a como “escapismo” e “divergionismo” (linha 110), apresenta um outro olhar sobre os fatos: o de que há “culpados” (linha 110) nessa situação.

O cotexto do enunciado e também a utilização do advérbio “deste momento" permitem-nos inferir que o referente textual ativado corresponde aos políticos governistas acusados de corrupção, já que, à época da interação, os investigados pela CPI, e pela CPMI, eram os petistas.

Sobre a formulação lingüística selecionada em (27), observamos que o próprio nomenúcleo - “culpados” - é dotado de valor negativo. Constatamos também que, além de proceder a um juízo indicativo de condenação ao referente textual, o senador César Borges (C.B.), por meio de uma descrição, avalia a situação política, aproveitando o cenário do programa. Observamos, nesse exemplo, a metáfora - o mar de lama - como recurso argumentativo enfatizado pela utilização da linguagem verbal ancorada à não-verbal, para produzir sentido, facilitando ao auditório a percepção do objeto como é apresentado pelo orador, conforme discutimos à página 94 deste trabalho.

Em seguida, observamos uma mudança de perspectiva no turno de José Eduardo Cardozo (J.E.C.), do PT, às linhas 207-209: 
(28)

J.E.C. [...] eu não tenho a menor DÚvida que:: nós temos que punir TOdos... envolvidos... Todos... sem exceção... inclusive não teremos nenhum problema em dar punições seVEras em quem usa a estrela no peito... mas discuTIR hoje... financiamento eleitoral e reforma poLÍtica... não é uma cortina de fumaça... é combater as causas... porque a corrupção eleitoral NÃO começou com o PT no governo... éh vem muito antes... não podemos taPAR... não podemos tapar o sol com a peneira tamBÉM sobre esse assunto

De fato, José Eduardo Cardozo (J.E.C.) parte de outro viés. Ele utiliza-se da formulação "quem usa a estrela no peito” (linha 209), para designar os petistas que estão envolvidos em denúncias de corrupção. Em relação a isso, como já indicamos à página 94 deste trabalho, a expressão metafórica, por ser um recurso de criação com alto grau de expressividade, ganha força argumentativa no contexto e colabora com a interpretação do interlocutor. Neste caso, o orador não apresenta o referente de maneira a desqualificá-lo (como ocorre em 25, 26 e 27), apenas enfatiza a qual grupo político o objeto pertence, ao colocar em evidência o símbolo do PT.

Ocorre esse procedimento, por parte de José Eduardo Cardozo (J.E.C.), em outros momentos do debate, como, por exemplo, às linhas 759-763 e 1131-1138 da transcrição em anexo, correspondente aos segmentos (29) e (30):

J.E.C. não estou sen/ olha... ( ) eu até comecei pelo inverso... tem que puNIR... tem que pegar todo mundo que tiver do PT tem que colocar na cadê::ia... está claro senador?... está claro... vamos separar isso... outra coisa não DÁ para dizer... que SUbitamente o Brasil acordou com uma revelação de que há caixa dois... em campanha eleitoral... com fala do senhor Delúbio... me desCULpe

J.E.C. [...] que a melhor maneira de nós mantermos esse patrimônio... é cortamos como diz o presidente "na carne”... assim que se comprovar o envolvimento de alGUÉM... do 
PT... militante dirigente parlamentar... ( ) nós temos que ser INtolerantes com aqueles que transgridem a ética e até tenho dito mais Markun... nós temos que ser TÃO ou MAIS intolerantes com aqueles do PT que transgridem a ética ... do que nós fomos no paSSAdo com nossos adversários... portanto eu acho que::: é:: o PT tem que nesse momento um momento difícil sem dúvida... mas é um momento... DIferencial da nossa história...se nós mostrarmos com clareza o que nós queremos que é investiGAR e punir... pessoas que estão envolvidas no NOsso campo [...]

Em (29) e (30), as formulações “todo mundo que tiver do PT” (linhas 759-760), “aqueles do PT que transgridem a ética” (linhas 1132-1133), “pessoas que estão envolvidas em nosso campo” (linha 1134) demarcam maior sutilidade no recorte selecionado do que vimos no exemplo (27), em que o referente é avaliado e julgado como “culpado”.

Além disso, nosso conhecimento de mundo permite-nos inferir que a posição de José Eduardo Cardozo (J.E.C.) sobre a necessidade de punir "aqueles do PT que transgridem a ética” (linha 1134) pode trazer à lembrança do auditório a história do Partido dos Trabalhadores que tem por base a defesa da ética, da igualdade, como já indicamos à página 67 deste trabalho.

Sobre esse procedimento, retomemos um dos imaginários de verdade apontado por Charaudeau (2005), indicado às páginas 66-67 deste trabalho: o da tradição. De acordo com o autor, o discurso da tradição pode fortalecer o argumento, ao apresentar as causas fundadoras, os valores de determinados grupos e, principalmente, o cumprimento de seus deveres.

Essa posição, de cumprimento do dever, coaduna-se com a de Maurício Rands, também do PT, que escolhe a seguinte formulação lingüística, linhas 1209-1212:

M.R. [...] o povo brasileiro SAbe... que o presidente Lula não tinha conhecimento de de desvios que foram cometidos nesses financiamentos de eleição... e por isso Ele como 
todos nós estamos empenhados a punir... punir quem seja do PT que tenha cometido irregularidade $[\ldots]$

Nesse caso, o orador seleciona a expressão “quem seja do PT que tenha cometido irregularidade” (linhas 1211-1212), para designar o objeto de (25), (27) e (28). Observamos que essa seleção é próxima à utilizada por José Eduardo Cardozo (“aqueles do PT que transgridem a ética”, linha 1134), tornando-se esse procedimento um indício de que ambos partem do mesmo ponto de vista, ou da mesma posição ideológica.

Sobre isso, o exemplo a seguir torna mais evidente a construção dinâmica do referente textual realizada por um grupo político. Vejamos o enunciado de Ideli Salvatti, também do PT, linhas 1175-1178:

I.S. [...] é dessa forma que nós estamos trabalhando sob a orientação dele... de combater... de investigar... e de punir... tudo e todos que estejam envolvidos com a corrupção... incluSIve... e talvez eu diria até... PRIoritariamente os nossos porque nós temos que dar o exemplo

Durante a formulação do segmento anterior, Ideli Salvatti reporta-se à orientação de Lula a respeito de "investigar e punir todos que estejam envolvidos com a corrupção” (linha 1177).

De acordo com o cotexto, podemos afirmar que Ideli Salvatti, primeiramente, parte de um termo amplo "tudo e todos que estejam envolvidos com a corrupção" (linha 1177). Posteriormente, ela faz um recorte e apresenta outro referente textual que, apesar de levar, por inferência, os atributos do objeto anterior “envolvidos com corrupção”, é construído de maneira a evidenciar que não apenas alguns petistas foram acusados de práticas ilícitas, mas também políticos de outros partidos. 
Ainda sobre o exemplo (32), a expressão utilizada “os nossos” torna evidente que a oradora fala como integrante de um grupo social, de um partido político. Sobre isso, remetemo-nos aos esquemas de grupo de Van Dijk (2003), indicados à pagina 50-52 deste trabalho. O autor afirma que a posição ideológica entre grupos manifesta-se nos planos cognitivo e discursivo, por meio de formas de polarização, como é o caso da seleção lingüística de Ideli Salvatti: “os nossos”.

As análises apresentadas no item 4.3.1 permitem que se apresentem dois quadros comparativos da (re)construção do objeto de discurso em questão. No primeiro quadro (07), agrupamos as seleções dos políticos da oposição; no segundo (08), as dos petistas:

\begin{tabular}{|l|l|}
\hline Falantes da oposição & Escolhas lingüísticas \\
\hline \multirow{2}{*}{ Denise Frossard, PPS } & $\begin{array}{l}{[\ldots] \text { uma cúpula... que capturou...o es-TA- }} \\
\text { do...bra-si-LEI-ro...numa organização } \\
\text { crimiNO::as }[. . .] \\
{[\ldots] \text { uma CÚpula... igual aquela que eu }} \\
\text { julguei...há treze anos [...] }\end{array}$ \\
\hline César Borges, PFL & $\begin{array}{l}{[\ldots] \text { os culPA::dos...DEste momento que }} \\
\text { conquistaram esse cenário aqui tão bem } \\
\text { representado um verdadeiro mar de LA::ma }[. . .]\end{array}$ \\
\hline
\end{tabular}

\begin{tabular}{|l|l|}
\hline Falantes do governo & Escolhas lingüísticas \\
\hline José Eduardo Cardozo, PT & $\begin{array}{l}{[\ldots] \text { quem usa a estrela no peito }[\ldots]} \\
{[\ldots] \text { todo mundo que tiver do PT }[\ldots]} \\
{[\ldots] \text { aqueles do PT que transgridem a ética }[\ldots]}\end{array}$ \\
& $\begin{array}{l}{[\ldots] \text { pessoas que estão envolvidas no NOsso }} \\
\text { campo }[\ldots]\end{array}$ \\
\hline Maurício Rands, PT & $\begin{array}{l}{[\ldots] \text { quem seja do PT que tenha cometido }} \\
\text { irregularidade }[\ldots]\end{array}$ \\
\hline Ideli Salvatti, PT & $\begin{array}{l}{[\ldots] \text { os nossos }((\text { referindo-se aos petistas acusados }} \\
\text { de corrupção) }[\ldots]\end{array}$ \\
\hline
\end{tabular}


Em geral, durante o debate, os políticos (re)ativaram, por vezes, o referente em questão conforme seu projeto de dizer e seu ponto de vista. Enquanto o grupo da oposição estabeleceu uma linha de sentido que orienta o telespectador a construir uma imagem dos petistas de “culpados” e de “criminosos", associando-os aos do governo Collor; os participantes governistas optaram por seleções lingüísticas marcadas pela ideologia do partido, pelo cumprimento do dever e pelo imaginário da tradição e o da soberania popular, encerrando valores que vão de encontro à tentativa de convencer o auditório a respeito da veracidade de seus discursos.

\subsubsection{Os depoentes}

Em seguida, passemos à análise da transcrição do texto, em anexo, em que alguns depoentes da CPMI são ativados e (re) construídos de maneira significativa no que concerne à tentativa de orientar argumentativamente o auditório por parte dos políticos debatedores.

Vejamos o enunciado desenvolvido por Denise Frossard (D.F.), do PPS (linhas 310312), em que, ao responder a pergunta lida por Paulo Markun (P.M.), linhas 252-259 do texto transcrito em anexo, a respeito da disputa partidária presente na Comissão Parlamentar de Inquéritos, menciona a respeito de Roberto Jefferson:

D.F. [...] nós estamos ali porque um depuTA::do fedeRAl que tinha a responsabiliDAde... de conduzir um partido como o senhor presidente... DI::sse que era assi::m [...] 
Observamos que a oradora, ao mencionar "um deputado federal” (linha 311), estabelece comparação com o presidente - numa tentativa de desqualificar a atitude de ambos no que se refere à função política de cada um.

Mais adiante, às linhas 356-357, Gustavo Fruet, da oposição, reativa o objeto de discurso ("Roberto Jefferson”) de maneira também a associá-lo ao governo e, assim, ao presidente:

G.F. [...] que nós temos que sepaRAR... o JOgo... político... entre oposição e situação... de um projeto maior de Estado... mas é bom lembrar... que agora teve uma fase da guerrilha e nós vamos na fase da qualificação... e tudo isso começou... a partir daquela gravação dos Correios... que levou Roberto Jefferson... a sentar... no Conselho de Ética... e ser proFUNdamente... ou sofrer uma tentativa profunda... de desqualificação... não é o bem contra o mal... não tem anjos nesta história... tem vítimas e cúmplices... e o Roberto Jefferson é bom lembrar... era da base do governo... e todas as denúncias que ele fez se referem à BAse do governo... há pessoas profundamente ligadas ao ministro José Dirceu... na busca de sustentação da BAse do governo no Congresso Nacional [...]

Gustavo Fruet (G.F.), na continuidade de seu discurso, às linhas 1019-1021, mantém suas colocações que associam a imagem de Roberto Jefferson ao governo Collor e, consecutivamente, ao governo de Lula. Desta vez, a tentativa é de apontar que o ministro José Dirceu conhecia o passado do deputado, mas, mesmo assim, o incluíra na "base do governo", como podemos observar no exemplo (35):

G.F. [...] O responsável pela denúncia por todo esse processo se chama Roberto Jefferson que acusado pelo PT na época do governo Collor... de ser da sua tropa de choque... ou seja o ministro José Dirceu... saBIa com quem estava lidando... não há ingênuo nessa história... 
Em (35), quando o enunciador (C.B.) reativa o referente textual, ele o faz de maneira a incluí-lo na "tropa de choque” do governo Collor. Nesse procedimento lingüístico, podemos afirmar que há tentativa de desqualificar tanto Roberto Jefferson, ao construir uma imagem de integrante de “um exército”, quanto José Dirceu e o governo Lula, em que a escolha da base do governo é apresentada de maneira pejorativa.

Sobre isso, reportemo-nos aos princípios de referenciação apontados por Koch (2006b), conforme indicamos às páginas 84-85 deste trabalho. De acordo com a estudiosa, durante o processo de ativação e de reativação de um referente textual, o mesmo poderá sofrer mudanças, ou mesmo receber outros recortes e avaliações, de acordo com a seleção lingüística do falante e da (re)ativação de outros objetos de discurso. Dessa maneira, a imagem construída do referente dependerá da atitude do (s) sujeito(s) durante o desenvolvimento do texto, já que este é produto da soma progressiva de suas partes.

Nos exemplos apresentados, (33), (34) e (35), depreendemos a mesma tentativa por parte de Denise Frossard (D.F.) e de Gustavo Fruet (G.F.) de desqualificar o objeto de discurso “Roberto Jefferson” e de associá-lo ao governo Lula.

A seguir, observaremos esse mesmo procedimento, também por parte dos políticos da oposição, de orientar argumentativamente a terceira parte - o telespectador - com seleções lingüísticas que imprimem ao objeto de discurso “Marcos Valério” valores pejorativos que podem ser associados ao grupo petista. Desta vez, desqualificando os referentes "Marcos Valério” e “Delúbio Soares” e, ao mesmo tempo, associando-os ao Partido dos Trabalhadores, Gustavo Fruet elabora o seguinte enunciado (linhas 1035-1037):

G.F. nós temos um contrato... que foi feito por partido... avalizado por empresário... que negou na CPI desrespeito à Comissão Parlamentar de Inquéritos... se descobriu um segundo contrato... e agora vem uma versão... que esse empresário num ato de benevolência... jamais vista na história do Brasil... faz um contrato no sistema 
privado... brasileiro... de quase quarenta milhões de reais atendendo um pedido de um amigo chamado Delúbio [...]

Nesse enunciado, Gustavo Fruet comenta sobre documentos descobertos pela Comissão Parlamentar de Inquéritos que apresentam dados a respeito de grande quantia de dinheiro direcionada ao PT, para fins de campanha eleitoral.

Em relação às expressões “empresário” (linha 1033) e “esse empresário” (linhas 1135), podemos inferir, pelo contexto histórico e pelo cotexto, que se refere a "Marcos Valério”, como atestam as teorias discutidas às páginas 85-86 deste trabalho a respeito da interpretação dos objetos de discurso constituída no processo inferencial que ativa os conhecimentos na memória do interlocutor de maneira associativa.

Em seguida, sobre o referente “um amigo chamado Delúbio”, é possível afirmar que se trata de um procedimento irônico utilizado pelo orador, juntamente com a expressão "num ato de benevolência”, com o possível intuito de orientar o olhar do auditório em relação ao tópico abordado.

César Borges, ao tratar do depoimento de Marcos Valério, faz a seguinte seleção lingüística para retomar o referente, às linhas 270-274 do texto transcrito em anexo:

C.B. [...] o Valério mentiu ele disse que só tinha um único aval... eu fiz essa pergunta diretamente a ele... ele disse que só tinha um único aval... de empréstimos... feitos ao PT... LOgo em seguida sai a versão de dois avais... agora aparece o Marcos Valério como aquele tomaDOR de recursos para o PT... recursos garantidos com o contra::to dos Correios... quer dizer ele mentiu [...]

Em (37), mais uma vez, depreendemos a tentativa de apresentar avaliações negativas sobre o referente, como procedimento argumentativo que pode orientar o interlocutor a entender Marcos Valério como “mentiroso”. A seleção “tomador” (linha 274) evoca valores pejorativos ao referente em questão, ou seja, desperta um olhar carregado de julgamento. Isso 
leva em conta as teorias apresentadas às páginas 86-91 deste trabalho sobre a seleção de expressões nominais como significativas escolhas que podem sustentar o ponto de vista do orador.

Assim também, a expressão “o Marcos Valério como tomador de recursos para o PT” (linhas 273-274) traz novamente à presença do auditório a acusação feita contra o empresário, envolvendo o Partido dos Trabalhadores.

As análises efetuadas no item 4.3.2 possibilitam que se apresentem dois quadros comparativos da (re)construção dinâmica dos referentes textuais e da tentativa, por parte da oposição, de relacionar depoentes/petistas/governo. No primeiro quadro (09), agrupamos as seleções a respeito do objeto "Roberto Jefferson” e, no segundo (10), sobre “Marcos Valério":

\begin{tabular}{|l|l|}
\hline Falantes da oposição & Escolhas lingǘsticas \\
\hline Denise Frossard, PPS & $\begin{array}{l}{[\ldots] \text { um depuTA::do fedeRAl que tinha a }} \\
\text { responsabiliDAde... de conduzir um partido } \\
\text { como o senhor presidente }[. . .]\end{array}$ \\
\hline Gustavo Fruet, PSDB & $\begin{array}{l}{[\ldots] \text { o Roberto Jefferson é bom lembrar... era da }} \\
\text { base do governo }[\ldots] \\
{[\ldots] \text { O responsável pela denúncia por todo esse }} \\
\text { processo se chama Roberto Jefferson que } \\
\text { acusado pelo PT na época do governo Collor... } \\
\text { de ser da sua tropa de choque }[. . .]\end{array}$ \\
\hline
\end{tabular}

Quadro 09

\begin{tabular}{|l|l|}
\hline Falantes da oposição & Escolhas lingüísticas \\
\hline \multirow{3}{*}{ Gustavo Fruet, PSDB } & $\begin{array}{l}{[. .] \text { que esse empresário num ato de }} \\
\text { benevolência... jamais vista na história do } \\
\text { Brasil... faz um contrato no sistema privado... } \\
\text { brasileiro... de quase quarenta milhões de reais } \\
\text { atendendo um pedido de um amigo chamado } \\
\text { Delúbio }[\ldots]\end{array}$ \\
\hline César Borges, PFL & $\begin{array}{l}{[\ldots] \text { agora aparece o Marcos Valério como }} \\
\text { aquele tomaDOR de recursos para o PT }[\ldots]\end{array}$ \\
\hline
\end{tabular}


Dessa maneira, nesta parte da análise, foi possível observar uma linha de sentido em que os depoentes foram construídos como "mentirosos", como "parceiros" do governo federal. Sobre isso, podemos afirmar que a atitude lingüística do grupo da oposição privilegiou a construção de uma imagem que leva em conta o valor de tortuosidade (Blisktein, 2002), ou seja, valor pejorativo que se distancia da ética, da honestidade; conforme apontamos à página 82 deste trabalho (quadro 04). Além disso, o exame das construções referenciais do grupo da oposição permite afirmar que houve várias tentativas de aproximação entre as desqualificações dos depoentes e as do governo Lula.

\subsection{As (não) verdades de cada um: a disputa de "realidades"}

Nesta parte, observamos como os políticos, por meio do processo de referenciação, disputam dinamicamente e discursivamente os efeitos de verdade, ou a verossimilhança do discurso (Perelman e Olbrechts-Tyteca, 1958, 2005), com o propósito de alcançar a adesão do auditório: o telespectador.

Os estudos de Charaudeau (2006a), indicados às páginas 62, 63, 64, 65 e 66, reportam-se à questão da construção e da disputa de sentidos e de efeitos de verdades estabelecidos nas relações sociais e interativas, em que os sujeitos, na ação de transformar o real em referente, fazem julgamentos, avaliações e classificações, e essa imagem construída do mundo sempre será direcionada a alguém, ou a uma sociedade.

No debate em exame, durante todo o seu processo interacional, foi possível constatar a disputa de verdades efetivada entre os grupos políticos; entretanto, em alguns momentos da interação, esse procedimento lingüístico apresentou-se de maneira significativa e marcante.

Um exemplo disso é o segmento em que José Eduardo Cardozo, Ideli Salvatti e Maurício Rands contestam, dinamicamente, a posição de Denise Frossard (linhas 139-145) a respeito 
do envolvimento do presidente nas denúncias de corrupção, comparando as declarações de Lula com as de Marcos Valério e as de Delúbio Soares. Vejamos as partes destacadas (linhas 172-190):

D.F.

pois é Markun... eu estava pensando aqui... com os olhos de quem viu... desfilar o crime na sua frente durante QUINze anos... eu estou vendo quem instruiu/ é como eu estivesse vendo o advoGAdo quem instruiu o réu chegou a minha presença... quem instruiu o DeLÚbio... foi o mesmo quem instruiu o Valério... e foi o mesmo que instruiu o presiDENte... isso faz portanto que o presidente entre no proCEsso... ONtem... eu levei uma tromBAda com isso... mas o presidente veio para dentro do proCEsso... o que o coloca na posição já de ser in-ves-ti-ga-do sim [...]

\section{J.E.C}

não... e eu agora levei um... porque eu confio no seu ( )... talvez eu esteja errado... mas o que ocorreu foi o seguinte Denise veja éh::... o presidente fez uma declaração... uma entrevista e o que disse o presidente? "Olha"/ se eu bem me lembro ele disse "olha o que acontece... no PT nas eleiÇÕES acontece com todo mundo" isso foi a frase mais contundente que ele utilizou... e aliás ele não precisou (ser) a caixa dois o que viria a ser et cetera... de onde se tira DISto... a idéia de que ele foi orienTAdo pelo mesmo advogado que orientou os dois?... eu não eu não acho

D.F.

eu imagino... da cabeça da juíza criminal

J.E.C. $\quad[$

só um pouquinho... só só um pouquinho só/ não não mas sim é mas eu acho [

M.R. é um salto lógico ((risos))

J.E.C é um salto lógico grande eu

I.S.

D.F.

$$
\text { imaginação criativa }
$$

finCAda nos fatos... calma senadora... finCAda nos fatos

Durante a interação, em (38), o enunciado de Denise Frossard (linhas 139-145) ganha rotulações avaliativas; a juíza defende-se, porém, a disputa torna-se ampla entre os debatedores.

Primeiramente, José Eduardo Cardozo rotula o discurso de Denise como “a idéia” (linha 177). Em seguida, o segmento rotulado ganha outras avaliações por parte do grupo governista: “um salto lógico” (linha 185), “um salto lógico grande” (linha 186), “imaginação 
criativa” (linha 188). Nessa última rotulação, a debatedora avaliada tenta reagir e completar a expressão com “fincada nos fatos” (linha 190), repetindo-a por duas vezes.

Detectamos que os participantes procedem à desqualificação do discurso da juíza, utilizando-se de seleções lingüísticas que apontam para a uma inadequação da “idéia” da oradora. Podemos afirmar que essa atitude, por parte dos petistas, apresenta tom irônico possivelmente reconhecido pelo contexto situacional e pela linguagem não-verbal que se associa à modalidade falada da língua, como o riso de Maurício Rands, ao pronunciar sua avaliação (“um salto lógico”).

Sobre essa tentativa de desqualificar o discurso e a imagem da juíza Denise Frossard, apontamos às páginas 89 deste trabalho, em Koch (2005), que as expressões nominais (“a idéia”, “imaginação criativa”) com função metadiscursiva podem ser utilizadas para avaliar uma ação ou uma atividade lingüística ou mesmo um processo mental de maneira a ironizar, contestar e também distanciar-se do enunciador e de seu ponto de vista.

Salientamos também que a utilização de definições (“é um salto lógico”, “é um salto lógico grande”) colaborou com a caracterização do discurso de Denise Frossard (D.F.), imprimindo-lhe avaliação negativa. Isso corrobora a postulação de Perelman e OlbrechtsTyteca $(1958,2002)$ para quem as definições oratórias correspondem a significativas seleções lingüísticas que possibilitam pôr em destaque determinadas características do referente que podem levar à (des)qualificação, conforme indicamos à página 76 deste trabalho.

Ainda sobre o exemplo (38), as teorias discutidas no capítulo III deste trabalho, páginas 104, 105 e 106, apontam para essa dinâmica que envolve as interações face a face. Isso é evidente nos debates entre políticos, pois a fala de um pode ser alvo de controvérsias, fazendo que haja reformulações e adaptações lingüísticas associadas a elementos, como gestos, entonações enfáticas (“finCAda nos fatos”), entre outros. 
Em seguida, analisamos outro segmento em que, desta vez, é a posição de José Eduardo Cardozo (J.E.C.) a avaliada e julgada por César Borges (C.B.), linhas 784-795:

J.E.C.

[...] eu vou lhe dizer que a Comissão de Justiça no deBAte de reforma política... VÁrios deputados faLAram... VÁrios deputados falaram... e o deputado Rands é testemunha... que nós tínhamos que aprovar uma reforma política... para acaBAR com a hipocriSIa desse sistema eleitoral e da (falta) de financiamento... inclusive GENte muito correta... do seu partido

C.B.

isso é cortina de fumaça... a questão é investigar... agora (quem) está passando o caixa dois e não querer... fazer... de um produto que nós vamos tirar da CPMI já no caminho da investigação

J.E.C.

você tem receio de combater você tem receio de combater essa questão senador? por que que o senhor tem tanto receio de combater essa questão cultural?

Nesse segmento, o enunciado rotulado é o de José Eduardo Cardozo. O discurso desse político, reportando-se à questão sobre a necessidade de uma reforma política, é encapsulado por César Borges como “isso” (linha 790), ganhando, posteriormente uma avaliação por meio de uma definição: “é cortina de fumaça”. Sobre isso, podemos afirmar que, apesar dessa expressão metafórica já ser de uso comum no contexto político, no cotexto, ela ganha força argumentativa para sustentar a tese que o senador quer defender: falar sobre reforma política é uma maneira de desviar a atenção, de mudar o tópico.

Sobre o procedimento de César Borges (C.B.), mais uma vez é possível afirmar que a utilização de definições colabora com a caracterização do referente, classificando-o de maneira a apresentar avaliações e julgamentos a seu respeito, como observamos no exemplo (38), às páginas 145-146.

Ainda sobre o exemplo (39), o deputado (J.E.C.) reage, selecionando a expressão “essa questão cultural” (linha 795) para rotular seu próprio discurso. Dessa maneira, 
depreendemos um jogo discursivo, uma disputa argumentativa pela qual são apresentadas ao auditório duas possíveis realidades: cortina de fumaça ou questão cultural? A decisão fica por parte do telespectador.

Outro exemplo dessa disputa ocorre às linhas 842-858 do texto transcrito. Nesse segmento, Maurício Rands e César Borges jogam com a (não) verdade de seus discursos:

M.R. agora... agora senador... vamos acabar... olha senador... vamos acabar com essa hipocrisia de dizer que “ah:: eu estou descobrindo ago::ra... que HÁ... recursos de campanha que não são escriturados” meu Deus... o estado brasileiro já dizia Raimundo ( ) é um estado patrimonialis::TA... e que uma minoria... historicamente já se apropriou deste esta::do... em que esta minoria reproduziu isso... num sistema poli::tico e que as eleições no Brasil... TOdos os brasileiros sabem... são feitas... sem que tudo seja descrimiNAdo

C.B.

inclusive pelo PT

M.R. e aí o que que nós queremos dizer?

C.B.

isso é réu confesso...admite isso agora não admitiu no passado... admite agora

Em (40), Maurício Rands (M.R.) rotula como "hipocrisia” (linha 842) o discurso elaborado por César Borges (C.B.) durante o debate "ah:: eu estou descobrindo ago::ra... que HÁ... recursos de campanha que não são escriturados” (linhas 843-844). O enunciador, ao utilizar do discurso direto, apresenta tom de sarcasmo, de zombaria, enfatizando seu ponto de vista.

Sobre as rotulações metadiscursivas, vimos, à página 90 deste trabalho, em Koch (2005), que essas formulações cumprem importante papel argumentativo, pois, por vezes, o segmento mencionado é atribuído à voz do outro enunciador de maneira a discordar e avaliar tanto o objeto de menção, quanto o sujeito que o enuncia. É o que ocorreu no turno de Maurício Rands (M.R.). 
Em contrapartida, César Borges (C.B.) refere-se ao segmento de Maurício Rands (M.R.) por meio do demonstrativo “isso" (linha 857), e o inclui na categoria "réu confesso" (linha 857), ou seja, de acordo com o senador, houve “confissão” por parte de alguém em julgamento (um réu).

A seguir, observamos um exemplo em que José Eduardo Cardozo (J.E.C.), partindo do mesmo ponto de vista de Maurício Rands (M.R.), em (39), defende a idéia de que o caixa dois não é uma questão do atual governo, mas algo já existente na política brasileira (linhas 954960):

J.E.C. [
Denise então só só retomando aquilo que eu ia falar... veja só...éh senador César
Borges... hoje no jornal eu acho que é a Folha de São Paulo... há uma declaração do
miNIStro do TSE... falando "HÁ caixa dois nas eleições... mas infelizmente nós não
temos como coibir”... ou seja é uma realidade TÃO noTÓria que até um juiz
respeitado reconhece... portanto pare::ce
a nota também é dele hoje

No exemplo anterior, José Eduardo Cardoso (J.E.C.), na tentativa de fortalecer seu ponto de vista, reporta-se a uma “declaração” (linha 955) veiculada pela Folha de São Paulo, utilizando-se do discurso direto "há caixa dois nas eleições, mas nós não temos como coibir" (linhas 956-957). O autor do discurso mencionado é construído como "ministro do TSE” (linha 956), “um juiz respeitado” (linha 957).

Sobre esse procedimento lingüístico, observamos que o objeto de discurso vai sendo construído de maneira a conferir-lhe autoridade (“juiz”) e credibilidade (“respeitado”). Em relação ao último, lembremos das afirmações de Perelman e Olbrechts-Tyteca $(1958,2002)$ sobre a utilização de epítetos e do papel argumentativo destes, enquanto modificadores e avaliadores do nome-núcleo, conferindo ao discurso o sentido de fato, conforme apontamos às páginas 75 deste trabalho. 
No próximo exemplo, é a vez da oposição construir o objeto de discurso, atendendo a seu propósito de sentido ou, melhor, sua “verdade” (linhas 455-467):

C.B. eu queria falar sobre esse assunto... porque éh:: este é o discurso... que o PT tem adotado... mas no FUNdo... no fundo... quando nós vamos averiguar há um desejo claro e nítido... de que... os trabalhos não avancem no ritmo desejado

J.E.C.

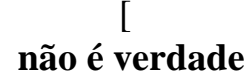

C.B. eu tenho chamo isso de uma ( )

J.E.C.

\section{não é verdade}

C.B. não... efetivamente... foi uma CPI chapa bran::ca... porque o Delcídio Amaral é o J.E.C. lí::der do PT no senado federal que é o presidente da CPI

$$
\text { está sendo parcial ( ) }
$$

Durante essa interação, o senador César Borges (C.B.) comenta a respeito da tentativa, por parte dos membros petistas da CPI, de impedir o avanço das investigações, alegando que a comissão é “chapa branca”, ou seja, que o PT detém o poder da situação.

Na continuidade de seu discurso, o orador constrói o referente textual “o Delcídio Amaral” (linha 464), “é o líder do PT no senado federal” (linhas 464-465), “é o presidente da CPI” (linha 465). A construção do referente é constituída progressivamente, apresentando informações resultantes de uma linha de sentido que atende ao ponto de vista do senador.

Sobre o procedimento de César Borges (C.B.), em (42), podemos afirmar que a expressão nominal referencial “o Delcídio Amaral” ganha características por meio da utilização de definições. Isso nos remete aos estudos de Perelman e Olbrechts-Tyteca (1958, 2002) em que as definições oratórias, como escolhas argumentativas, possibilitam a caracterização do referente, conforme indicamos à página 76 deste trabalho.

Por outro lado, José Eduardo Cardozo (J.E.C.) nega a afirmação de seu opositor, repetindo, por duas vezes, “não é verdade” (linhas 459 e 463). Isso explicita, mais uma vez, o 
jogo de verdades instaurado nesse encontro, em que a voz de um é contestada pela do outro e, assim, estabelece-se o debate entre os políticos.

De maneira geral, durante o processo interacional, observamos um jogo dinâmico entre grupos políticos. As idéias apresentadas por cada um, por vezes, foram encapsuladas e avaliadas de maneira pejorativa, numa tentativa de contestar, de apresentar um outro julgamento e, também, de direcionar o olhar para outras questões julgadas desconhecidas ou importantes para serem reforçadas.

\subsection{Conclusão das análises}

Verificamos, pelas análises realizadas, que o corpus deste trabalho, por se enquadrar em um espaço propenso a um jogo ideológico/discursivo, possibilitou a observação de orientações argumentativas construídas dinamicamente por grupos políticos por meio de estratégias nominais de referenciação.

No exórdio do programa Roda Viva, item 4.1 da análise apresentada, examinamos que a maneira como a instância enunciadora organizou o debate - a escolha dos participantes, a produção do cenário, os tópicos discursivos abordados, a apresentação da situação interativa e, principalmente, as seleções lingüísticas referenciais - já instaurou uma situação de disputa entre os debatedores, inserindo-os em distintas posições partidárias e também direcionou para um olhar perceptivo-interpretativo sobre os tópicos debatidos.

Observamos que a mídia, utilizando-se de recursos verbais e não-verbais, desenvolveu o exórdio de maneira a conferir valores pejorativos às situações políticas colocadas em evidência e às pessoas envolvidas na questão. Em outras palavras, podemos afirmar que houve tanto a tentativa de construir uma imagem de "sujeira” - um mar de lama - a respeito de alguns acontecimentos políticos, quanto de apresentar a necessidade, ou a 
responsabilidade, de atitude por parte dos políticos para resolverem o que a instância midiática denominou “Crise política e corrupção 2005”.

Dessa maneira, os políticos, por estarem situados num momento de trocas de idéias e de disputa partidária/ideológica provocado pela mídia, dispuseram de seus conhecimentos de mundo para reconhecer o objetivo do encontro (o gênero discursivo), e utilizaram-se de seu repertórios lingüísticos para avaliar e (des) qualificar o que julgaram necessário conforme seu projeto de sentido. E por essa ação linguageira, ou mais especificamente, por meio dos processos referenciais - como estratégia argumentativa -, pudemos depreender um jogo discursivo/argumentativo durante a situação interacional, entre os grupos políticos.

Nos itens 4.2, 4.2.1 e 4.2.2, a construção dinâmica do objeto de discurso “o presidente da República”, “o presidente lula” etc, serviu-nos de pistas para detectar uma disputa de imagens, de "realidades”. O grupo da oposição apresentou o referente como alguém fraco, sem atitude, e envolvido com as denúncias de corrupção: “o presidente da República que prometeu fazer diferente”, linhas 1108-1109; “o maior responsável (pela corrupção) é o presidente da República”, linha 185; “isso (falta de atitude do presidente) constitui-se um crime de responsabilidade”, linha 1190 etc. Já os políticos do governo privilegiaram a força, o “comando”, a integridade: “como disse (o presidente) “investir em mim...vamos cortar na própria carne” que é o comando que ele tem dado a nós”, linhas 1127-1128; “o presidente que tem dado uma demonstração clara” (sobre a ação de combater a corrupção), linha 1167; “a pessoa mais preparada para combater a corrupção”, linha 1172.

Essa negociação de sentido instaurada entre os políticos também foi depreendida no exame de outras (re) construções durante o debate, nos itens 4.3, 4.3.1 e 4.3.2. As personalidades políticas envolvidas em denúncias de corrupção (os petistas, o Roberto Jefferson, o Marcos Valério, o ex-presidente Collor) receberam julgamentos e recortes distintos por parte dos grupos debatedores. Valores como honestidade e ética, assim também o 
combate à corrupção, conferiram, mais uma vez, a linha de sentido proposta pelos petistas (quadro 08, página 136). Em contrapartida, os outros políticos encaminharam seus discursos de maneira a incluírem seus referentes em categorias que apresentaram valores negativos: “uma cúpula que capturou o Estado brasileiro numa organização criminosa”, linhas 11511152; “culpados”, linha 110; entre outras (quadro 07, página 137).

Importa-nos ressaltar que a (re) construção conjunta desses objetos de discurso possibilitou detectar uma inter-relação de sentido entre eles. Ou seja, levando-se em consideração todo o processo interacional, foi possível observar uma rede referencial resultante de uma linha de sentido "global” negociada entre os políticos e constituída interdiscursivamente pela soma das partes evidenciadas dos referentes textuais (re) ativados por cada grupo, num processo metonímico e metafórico.

Sobre esse último ponto, podemos afirmar que houve associação entre as imagens (re) construídas do presidente, dos petistas acusados, dos depoentes e, também, das avaliações por meio de rótulos a respeito das ações desses políticos. Se posicionarmos um olhar sobre as questões argumentativas apresentadas no capítulo II deste trabalho, à página 71, poderemos afirmar que a relação entre membro e grupo, ou político e partido foi utilizada, por diversas vezes, durante o debate, por meio das estratégias nominais referenciais, para convalidar as teses apresentadas. Em outras palavras, a (des)qualificação do presidente Lula, por exemplo, também pode ser atribuída aos membros de seu partido, e vice-versa.

Além disso, essa constituição de sentido por meio da inter-relação das imagens (re) construídas de certos objetos de discurso foi possível de se depreender pela maneira como o grupo da oposição construiu o objeto “Roberto Jefferson”, comparando-o com o presidente Lula: “um depuTA::do fedeRAl que tinha a responsabiliDAde... de conduzir um partido como o senhor presidente” (linha 310-311). Nessa expressão, a atitude dos dois políticos é questionada e associada, o que ocorre também por meio das seleções lingüísticas: “o 
presidente da República... que prometeu fazer diferente”; “o maior responsável ((pela corrupção)) é o presidente da República”; “o Roberto Jefferson é bom lembrar... era da base do governo”; entre outras.

Dessa maneira, observamos que houve intersecção das partes selecionadas sobre ambos os referentes textuais (Roberto Jefferson e presidente Lula) a respeito de suas atitudes e seus envolvimentos com a corrupção, conferindo-lhes uma imagem negativa. Assim também ocorreu com a construção do referente "Marcos Valério” e sua associação com o Partido dos Trabalhadores e, consecutivamente, com o governo federal: “o Marcos Valério... aquele tomador de recursos para o PT” (linhas 273-274) etc.

Em geral, pelas análises dos itens 4.2-4.3, depreendemos uma situação discursiva em que a disputa partidário-ideológica entre os grupos propiciou que se apresentassem alguns referentes textuais de maneira a evidenciar características negativas e a desqualificar os políticos tidos como opositores. Assim, a utilização dos processos nominais referenciais, interagindo com o contexto e o cotexto, constituíram-se, também, como estratégia argumentativa para convalidar a tese que cada grupo defendeu.

Já no item 4.4, examinamos que as estratégias referenciais argumentativas foram utilizadas para (des) qualificar, dinamicamente, opiniões e teses dos participantes, durante o processo interacional. Nessa parte das análises, tornou-se evidente o jogo discursivo efetivado no debate, em que a seleção de encapsulamentos, de rótulos metadiscursivos acompanhados de definições possibilitou que observássemos várias tentativas de contestar a idéia do adversário, numa situação em que a ação e a reação lingüística de cada um puderam ser examinadas como tentativas de apresentar ao telespectador realidades distintas sobre determinados fatos (“cortina de fumaça ou questão cultural?”, exemplo 39).

Salientamos que, por diversas vezes, a (re) construção do referente textual constituiuse pela seleção de expressões nominais acompanhadas de definições, como: “Qual é a pessoa 
mais preparada para combater a corrupção?”, “o presidente Lula” (linhas 171, 172, 173); “o Delcídio Amaral” (linha 464), “é o líder do PT no senado federal” (linhas 464-465), “é o presidente da CPI” (linha 465).

As expressões nominais acompanhadas de definições também foram selecionadas para avaliar e contestar determinadas atitudes lingüísticas e posicionamentos dos políticos, como: “a idéia” (linha 177), “é um salto lógico” (linhas 172-173), “é um salto lógico grande” (linha 186), “imaginação criativa” (linha 188); “isso é réu confesso” (linha 857); "não é verdade” (linhas 459 e 463).

Esse procedimento apresentou-se de maneira recorrente durante a situação interacional. Dessa maneira, podemos afirmar que a utilização de definições, no corpus analisado, colaborou com a construção de objetos de discurso de maneira a conferir-lhes valores argumentativos. Isso corroborou a postulação de Perelman e Olbrechts-Tyteca (1958, 2002) para quem as definições correspondem a recursos significativos que possibilitam orientação argumentativa.

De maneira geral, a fabricação discursiva de realidades foi disputada durante o programa Roda Viva, estabelecendo uma "luta discursiva” (Charaudeau, 2006b), um jogo, cujos participantes procederam conforme a intencionalidade do encontro e as ações e as reações lingüísticas apresentadas no debate. 
CONSIDERAÇÕES FINAIS 


\section{Considerações finais}

No decorrer deste trabalho, procedemos à discussão de teorias que possibilitassem uma associação entre as questões a respeito da argumentação e as voltadas aos processos referenciais dentro de um determinado contexto situacional: o debate político televisivo. Consideramos que a prática de designação de referentes textuais, por ser uma atividade discursiva, apresenta o caráter vivo, dinâmico, intersubjetivo e criativo específico da ação de discursivizar o mundo realizada por sujeitos sociais.

E ainda observamos que, por ser a referenciação efetivada pelo uso da língua, a argumentatividade, inerente a esta, permanece presente nas seleções lingüísticas utilizadas com o propósito de designar e, possivelmente, avaliar, julgar e construir realidades textuais. As formulações lingüísticas foram vistas como portadoras de valores apreendidos e reconhecidos, positiva ou negativamente, por nossa sociedade, não de maneira unânime, mas fazendo parte de um quadro cultural-histórico-ideológico significativo na construção intersubjetiva, perceptiva, interpretativa e avaliativa de determinados objetos.

Privilegiamos as estratégias nominais referenciais selecionadas durante o debate do programa Roda Viva; entretanto, não objetivamos dar conta de todas as seleções apresentadas pelos políticos, mas sim depreender algumas que possibilitassem examinar as orientações argumentativas efetivadas de maneira dinâmica por meio dos processos de referenciação.

Ao salientarmos o processo referencial como estratégia argumentativa que colabora com o direcionamento de sentido pretendido pelo enunciador, também levamos em conta toda a situação de produção em que se encontravam os políticos. Desde a maneira como a mídia organizou o debate e apresentou pontos de vista por meio de recursos verbais e não-verbais, até as ações e reações dos debatedores. 
Pelas análises efetuadas, pudemos constatar que a orientação argumentativa não se efetiva pela simples seleção de expressões nominais, mas pela maneira como essas no momento da enunciação tomam direcionamentos que servem para sustentar as teses defendidas pelos seus enunciadores.

Isso permitiu que observássemos a complexidade que envolve a (re) construção referencial, pois esta se estabelece durante a interação, nas disputas discursivas entre os políticos e nos variados elementos lingüísticos e extralingüísticos mobilizados pelos participantes e pela organizadora do encontro. Esse jogo interacional tornou-se elemento significativo para que pudéssemos depreender o dinamismo que envolve os processos referenciais em situações face a face; tanto se pensarmos a construção do referente como produto das partes evidenciadas por cada enunciador, num processo que envolve associação e soma de informações e de propriedades, quanto se levarmos em conta o imediatismo de ação e de reação exigido pelas práticas orais.

Diante dessa situação de produção, em que vários pontos de vista estavam interagindo (debatedores, mídia e terceira parte), podemos dizer que os participantes elaboraram argumentativamente seus discursos de maneira cooperativa entre grupos políticos e, consecutivamente, encaminharam a interação contestando e desqualificando a atitude de seus opositores. Nesse sentido, o percurso realizado com a pesquisa permitiu confirmar a existência de uma oposição ideológica de grupos (Van Dijk, 2003) que, fazendo parte dos processos cognitivos dos sujeitos, como representantes de partidos políticos, registrou-se nos discursos dos debatedores.

Essa oposição ideológica propiciou que os participantes desenvolvessem enunciados de maneira a evidenciar características positivas de seu grupo e negativas do seu adversário. No caso de nosso corpus, políticos, partidos e governos foram qualificados ou desqualificados por meio de associações. 
Esse procedimento corroborou a postulação de Perelman e Olbrechts-Tyteca (1958, 2002) a respeito da postura argumentativa de determinados enunciadores de associar membros e grupos. Assim, a atitude unânime de desqualificar o governo de Lula por parte dos políticos da oposição foi acompanhada por várias tentativas de apresentar o Partido dos Trabalhadores e os petistas também de maneira negativa. Por outro lado, o grupo do governo procedeu a contestações a respeito da posição de seus adversários e a avaliações positivas sobre seu grupo político.

Evidenciamos, em nossos estudos a respeito da argumentação a importância de se adaptar o discurso ao auditório em questão, para que se efetivassem, o mais próximo possível, os efeitos de sentido almejados e os propósitos argumentativos do enunciador.

O corpus examinado permitiu constatar que, em todo processo interacional, as atitudes lingüísticas dos debatedores levaram em conta a participação da terceira parte. Isso pôde ser observado nos discursos dos políticos debatedores que privilegiaram efeitos de tradição, de modernidade e de soberania popular (Charaudeau, 2005b), fazendo com que a importância do auditório (o telespectador) fosse evidenciada.

De maneira geral, a discussão teórica e as análises realizadas dos processos referenciais do ponto de vista argumentativo permitiram que observássemos uma disputa de realidades instaurada entre os políticos na situação de debate. As seleções lingüísticas apresentadas nesse encontro foram elementos indicativos de tentativas de agir sobre o auditório e de modificar contextos (esquemas mentais). 


\section{Referências Bibliográficas}

APOTHÉLOZ, D. (2003). Papel e funcionamento da anáfora na dinâmica textual. In. CAVALCANTE, M. M.; RODRIGUES, B.B.; CIULLA, A. (org.). Clássicos da Lingüística 1. Referenciação. São Paulo: Contexto, p. 53-84.

AQUINO, Z. G. O. de (1997). Conversação e conflito: um estudo das estratégias discursivas em interações polêmicas. Vol I e II (Tese de Doutoramento). São Paulo: Universidade de São Paulo.

. (2005). Reflexões sobre a argumentação no discurso político. SILVA, L. A (org.). A língua que falamos. Português: história, variação e discurso. São Paulo: Globo, p. 105-118.

BAKHTIN, M. (1990) Marxismo e Filosofia da Linguagem. 5 ed. São Paulo: Hucitec. (1929). . (1992). Estética da Criação Verbal. São Paulo. São Paulo: Martins Fontes.

BLACKLEDGE, A. (2005). Discourse and power in a multilingual world. Discourse approaches to politics, society and culture. Amsterdam/Philadelphia: John Benjamins Publishing Company.

BLIKSTEIN, I. (2002). Kaspar Houser ou a Fabricação da Realidade. São Paulo: Cultrix.

CAVALCANTE, M. M. (2003a). Expressões referenciais - Uma proposta classificatória. Cadernos de Estudos Lingüísticos. Campinas, v. 44, p. 105-118.

. (2003b). A construção do referente no discurso. Fascículo 7 do curso de formação continuada de professores de rede pública - Universidade aberta do nordeste - Fundação Demócrito Rocha. Fortaleza.

; RODRIGUES, B. B.; CIULlA, A. (org.) (2003c). Clássicos da Língüística Referenciação. São Paulo: Contexto.

CHARAudeAU, P. (2006a). Discurso das mídias. Tradução Ângela M. S. Corrêa. São Paulo: Contexto.

• (2006 b). Discurso político. Tradução Dilson Ferreira da Cruz e Fabiana Komesu. São Paulo: Contexto.

CHILTON, P. A. (2004). Analysing political discourse. United Kingdon: Routledge.

CONTE, M. E. (2003). Encapsulamento anafórico. In. CAVALCANTE, M. M.; RODRIGUES, B.B.; CIULLA, A. (org.). Clássicos da Lingüística 1. Referenciação. São Paulo: Contexto, p. 177-190.

FRANCIS, G. (2003). Rotulação do discurso: um aspecto da coesão lexical de grupos nominais. In. CAVALCANTE, M. M.; RODRIGUES, B.B.; CIULLA, A. (org.). Clássicos da Lingüística 1. Referenciação. São Paulo: Contexto, p. 191-228. 
CORNISH, F. (1999). Anaphora, Discourse, and Understanding: evidence from english and french. New York: Oxford University Press.

CORTEZ, S. L. (2003). Referenciação e construção do ponto de vista. (Dissertação de mestrado). Campinas: Universidade de Campinas.

DESTUTT DE TRACY, A. L. C. (1970). Éléments d'idéologie. In: Bibliothéque des textes philosophiques. v.2. Paris: Librairie Philosophique J. Vrin. (1801).

FAIRCLOUGH, N. (1996). Rethoric and Critical Discourse Analysis: a reply to Titus Ensik Christoph Sauer. Language and Society. Cambridge, v. 3, n. 3, p. 286-289.

FÁVERO, L. L.; ANDRADE, M. L. C. V. O.; AQUINO, Z.G.O. de . (1998). Discurso e interação - a reformulação nas entrevistas. DELTA - Revista de Documentação de Estudos em Lingüística Teórica e Aplicada. São Paulo, v. especial, p. 91-104.

FÁVERO, L. L.; ANDRADE, M. L. C. V. O. (1999). Os processos de representação da imagem pública nas entrevistas. In: PRETI, D. (org.). Estudos de língua falada. Variações e confrontos. Projetos Paralelos - NURC/SP 3. 2 ed. São Paulo: Humanitas, p.153-177.

GUIMARÃES, E. (1999). Figuras de retórica e argumentação. In. MOSCA, L. L. S. (org.). Retóricas de ontem e de hoje. São Paulo: Humanitas, p. 145-160.

HIGGINBOTHAM, DJ.; MATHY-LAIKKO, P.; YODER, D. E (1998). Studying conversations of augmentative communication system users. In: BERNSTEIN, L.(org.). The vocally impaired: Clinical practice and research. New York: Grune \& Stratton, p. 265-294.

ILARI, R. (org.). (1992). Gramática do português falado: níveis de análise lingüística. v.2. Campinas: Editora da Unicamp.

KERBRAT-ORECCHIONI, C. (1996). Texte et contexte. In: SCOLA, n.6., número especial, p. 40-59.

KOCH, I. V. (1996). Argumentação e linguagem. 9. ed. São Paulo: Cortez.

. (2000). A inter-ação pela linguagem. São Paulo: Contexto.

. (2001). A referenciação como atividade cognitivo-discursiva e interacional. In: II Congresso Internacional da Abralin. Anais. v. 1. Boletim da Associação Brasileira de Lingüística. v. 26. Número especial. Fortaleza, p. 81-84.

. (2005). Referenciação e orientação argumentativa. In. KOCH, I., V.; MORATO, E. M.; BENTES A. C. (org.). Referenciação e Discurso. São Paulo: Contexto, p. 33-52.

. (2006a). Linguagem e cognição: a construção e reconstrução de objetos de discurso.

Veredas. Juiz de Fora, v. 6, n. 1, p. 29-42.

. (2006b). Desvendando os segredos do texto. 5. ed. São Paulo: Cortez. 
KOCH, I. V.; MARCUSCHI, L. A. (1988). Processos de referenciação na produção discursiva. DELTA. São Paulo, v. 14, número especial, p. 169-190.

; _ـ (2003). Linguagem e cognição: os (des)encontros entre a lingüística e as ciências cognitivas. Cadernos de Estudos Lingüísticos. Campinas, v. 44, n. 44, p. 85-91.

KOCH, I. V.; SILVA, A. C. B. da. (2003). Gênero, mídia e recepção: sobre as narrativas televisivas e seus espectadores. Cadernos de Estudos Lingüísticos. Campinas, v. 44, n. 44, p. 265-282.

LAKOFF, George; JOHNSON, Mark. (1980). Metaphors we live by. Chicago: Harvard University Press.

(1993). The contemporary theory of metaphor. In: ORTONY, A. (ed.). Metaphor and Thought. Cambridge: CUP, p.202-252.

LIMA, M. L. (2005). Referenciação e investigação do processamento cognitivo: um exemplo do indefinido anafórico. In. KOCH, I., V.; MORATO, E. M.; BENTES A. C. (org.). Referenciação e Discurso. São Paulo: Contexto, p. 197-218.

MARCUSCHI, L. A. (1994). Contextualização e explicitude na relação entre fala e escrita. In: Anais do I ENCONTRO NACIONAL SOBRE LÍNGUA FALADA E ENSINO. Universidade Federal de Alagoas, Pós-Graduação em Letras, p.27-48.

• (2001a). Análise da Conversação. 5. ed. São Paulo: Ática.

(2001b). Atos de referenciação na interação face a face. In: II Congresso Internacional da Abralin. Anais. v. 1. Boletim da Associação Brasileira de Lingüística. v. 26. Número especial. Fortaleza, p. 71-77.

. (2001c). Da fala para a escrita. Atividades de retextualização. São Paulo: Cortez.

. (2002a). Do código para a cognição: o processo referencial como atividade criativa.

Veredas. Juiz de Fora, v. 6, n.1, p. 43-62.

(2002b). Gêneros textuais: definição e funcionalidade. In: DIONÍSIO, A. P.; MACHADO, A. R.; BEZERRA, M. A. (orgs.). Gêneros textuais e ensino. Rio de Janeiro: Lucerna, p. 19-36.

. (2004). O léxico: lista, rede ou cognição social?. In: NEGRI, L.; FOLTRAN, M. J.; OLIVEIRA, R. P. de (org.). Sentido e Significação: em torno da obra de Rodolfo Ilari. São Paulo: Contexto, p. 263-284.

MARCUSCHI, L. A; KOCH, I.V. (2002). Estratégias de referenciação e progressão referencial na língua falada. In: ABAURRE, M. B. M.; RODRIGUES, A. C. S. (org.). Gramática do português falado. Novos estudos descritivos. Campinas: Editora Unicamp, v. 8, p. 31-56. 
MILNER, J.C. (2003). Reflexões sobre a referência e a correferência. In. CAVALCANTE, M. M.; RODRIGUES, B.B.; CIULLA, A. (org.). Clássicos da Lingüística 1. Referenciação. São Paulo: Contexto, p. 85-130.

MONDADA, L. (2001). Gestion du Topic e organization de la conversation. Cadernos de Estudos Lingüísticos. Campinas, v. 41, p. 7-36.

. (2002). Cognition et parole-en-interaction. Veredas. Juiz de Fora, v. 6, n. 1, p. 9-27.

(2005a). A Referência como trabalho interativo: a construção da visibilidade do detalhe anatômico durante uma operação cirúrgica. In. KOCH, I., V.; MORATO, E. M.; BENTES A. C. (org.). Referenciação e Discurso. São Paulo: Contexto, p. 11-31.

MONDADA, L. (2005b). L'exploitation située de ressources langagières et multimodales dans la conception collective d'une exposition. In. LAURENT, F.; BRONCKART, J. P. (org). L'Analyse des actions et des discours en situation de travail: concepts, methods et applications. Louvain-la-Neuve: Peers, p. 135-154.

MONDADA, L.; DUBOIS, D. (2003). Construção dos objetos de discurso e categorização: Uma abordagem dos processos de referenciação. In. CAVALCANTE, M. M.; RODRIGUES, B.B.; CIULLA, A. (org.). Clássicos da Lingüística 1. Referenciação. São Paulo: Contexto, p. 17-52.

OLERÓN, P. (1983). A argumentação. Tradução Cascais Franco. Portugal: EuropaAmérica Lda.

OSAKABE, H. (1999). Argumentação e Discurso Político. 2. ed. São Paulo: Martins Fontes.

PERELMAN, C. (1997). Retóricas. Tradução Maria Ermantina Galvão G. Pereira. São Paulo: Martins Fontes.

. (1999). O império Retórico: retórica e argumentação. Porto: ASA.

; OLBRECHTS-TYTECA, L. (2002). Tratado da argumentação. A Nova Retórica. Tradução Maria Ermantina Galvão. São Paulo: Martins Fontes. (1958).

POTTER, J. (org.). (1996). Representing reality: discourse, rhetoric and social construction. 3. ed. London: Sage Publications. (2005). Conversation and Cognition. Cambridge: Cambridge University Press.

PRETI, D.(1991). A linguagem da TV. O impasse entre o falado e o escrito. In: NOVAES, A. (org.). Rede imaginária. Televisão e democracia. São Paulo: Schwarcz, p.232-239. . (org.). (1999). Estudos de língua falada. Variações e confrontos. Projetos Paralelos NURC/SP 3. São Paulo: Humanitas.

(2003). Alguns problemas interacionais da conversação. Interação na fala e na escrita. Projetos Paralelos - NURC/SP 5. São Paulo: Humanitas. 
ROCCO, M. T. F. (1991). As palavras na TV. Um exercício autoritário? In: NOVAES, A. (org.). Rede imaginária. Televisão e democracia. São Paulo: Schwarcz, p.240-256.

VAN DIJK, T. A. (1992). Cognição, discurso e interação. São Paulo: Contexto. . (1997). Discourse as social interaction. London: Sage Publications. . (2003). Ideologia y discurso. Una introducción multidisciplinaria. Barcelona: Ariel. . (2004a). Politics, ideology and discourse. In: WODAK, R. (Ed.). Language and Politics. Encyclopedia of language and linguistics. Disponível em:

<http://www.discourse-in-society.org/teun.html>. Acesso em: 10 maio 2005.

(2004b). Ideology and discourse analysis. Disponível em: <http://www.discourse-insociety.org/teun.html>. Acesso em: 24 nov. 2005.

. (2004c). Critical Context Studies. In: CDA. Congresso de Valência. Disponível em: $<$ http://www.discourse-in-society.org/teun.html>. Acesso em: 10 maio 2006.

(2005a). Discurso, conocimiento e ideologia. Reformulación de viejas cuestiones y propuesta de algunas soluciones nuevas. Disponível em:

<http://www.discursos.org/Discurso,\%20conocimiento\%20e\%20ideologia.htm>. Acesso em: 24 nov. 2005.

(2005b). Discurso, Notícias e Ideologia. Estudos na Análise Crítica do Discurso. Tradução de Zara Pinto-Coelho. Porto: Campo das Letras. 


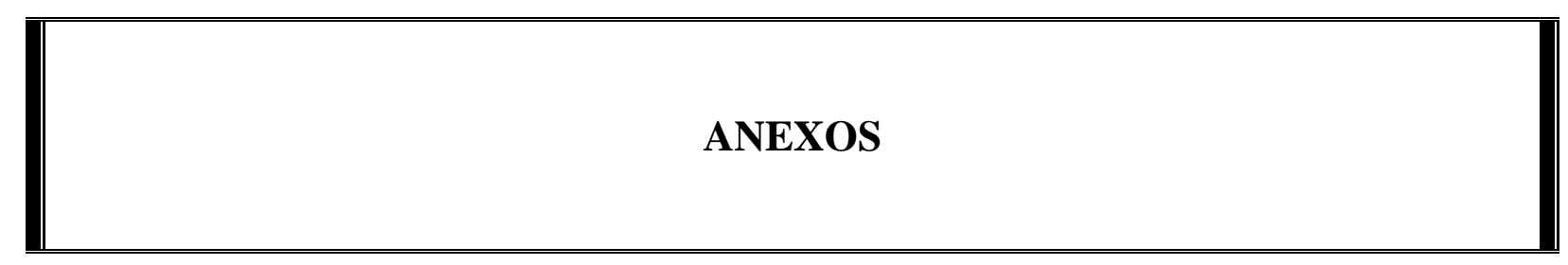




\author{
Anexos \\ Programa Roda Viva - O Brasil passa por aqui \\ Duração: 85 minutos aproximados \\ Supertópico: Crise política e corrupção 2005 \\ Data: 15 de julho de 2005
}

\begin{abstract}
P.M = Paulo Markun; N = Narrador; M.V. = Marcos Valério; I.S. = Ideli Salvatti; C.B. = César Borges; M.R. = Maurício Rands; D.F. = Denise Frossard; J.E.C. = José Eduardo Cardozo; G.F. = Gustavo Fruet.
\end{abstract}

P.M. boa noite... um funcionário público é flaGRAdo receben::do... o que parece uma proPÍna de três mil reais... e o que de início... PAreceu vamos dizer assim... um CAso coMUN:: de corrupção... acabou provocando uma crise política que saBEmos como começou... mas não sabemos como VAi terminar... que crise é essa? que desdobramentos ela pode ter? é o TEma do debate especial que fazemos hoje no Roda Viva... nas pegadas de uma TRIlha... que ao ser investiGAda... torna mais viSÍvel... a fase coRRUpta do Brasil... uma situação que desafia governo e INStituições a agir... e limPAR a lama que quase sempre marca as relações entre dinheiro e política

((filme que relata o caso de Roberto Jefferson e apresenta cenas da CPI, incluindo trechos do depoimento de Marcos Valério))

N o flagrante de suposta propina acaba envolvendo um deputado importante da base de apoio do governo... ameaçado ele se transforma em homem-BOMba e explode algo maiOR... das corrupções dos Correios às denúncias do mensaLÃO... o Congresso Nacional ferVEU... abriu conflito entre governo e oposição... e deixou o país perplexo com a nova onda de denúncias... barrada inicialmente por governistas... a CPI Mista dos Correios finalmente foi criada... e em menos de um mês de trabalho... ouviu quatro personagens importantes da crise... Maurício Marinho o homem dos três mil reais... Roberto Jefferson... que fez a denúncia de propina mensal de TRINta mil reais... a deputados aliados ao governo... Marcos Valério publicitário apontado por JEfferson como operador do mensalão... e Fernanda Karina Somaggio exsecretária de Valério... testemunhando que o ex-padrão fazia grandes saques em bancos... com depoimentos em geral marcados por tumultos e exaltações... a semana que passou foi TENsa... e tudo volta a esquentar ainda mais aGOra... depois que Marcos Valério decidiu abrir o jogo e confessar... ter montado uma operação mi::lionária de crédito... para financiar o PT... a pedido de Delúbio Soares ((em seguida são incluídos trechos de uma entrevista televisiva em que Marcos Valério comenta sobre os empréstimos))

M.V. e foi no decorrer de dois mil e três... e dois mil e quatro... que essas empresas... tomaram vários empréstimos bancários... há um monTANte... e repassou esses empréstimos bancários... ao ParTIdo dos Trabalhadores... ((corte)) foi a pedido é do::: do tesoureiro e::: e sempre indicando as pessoas que iriam saCAR ou a::: a empresa que iria ser transferido o recurso... ((aqui percebe-se o corte da gravação, direcionando para um outro trecho da entrevista com o publicitário)) foi doutor Delúbio Soares que me pediu que eu fizesse o empréstimo ((outro recorte)) o empréstimo... eu te diria que não foi... Ao partido... mas a peSSO::a... que me pediu... ((outro recorte)) mas eu posso:: te adiantar uma coisa... uma... nunca foi... relacionado... e pelo que eu tenho conhecimento... pelo o que eu assisti... e pelo o que eu:: CONversei com o:: tesoureiro... nunca foi relacionado a nenhum mensaLÃO (( a cena é cortada, mostrando novamente o programa Roda Viva)) 
P.M. PAra discutir a crise política os conflitos a disputa partiDÁria... e os possíveis rumos da investigação... reunimos neste debate no Roda Viva... seis integrantes da CPI dos Correios... três que representam a oposição... e três que representam o partido do governo... José Eduardo Cardozo deputado federal pelo PT paulista advogado... foi presidente da CÂmara municipal de São Paulo em dois mil e um... e presidiu a CPI da MÁfia do Comércio Ambulante da capital em noventa e cinco... e em noventa e nove presidiu a CPI... da MÁfia dos Fiscais... Ideli SalVAtti do PT primeira senadora de Santa Catarina... liderou a bancada do Partido dos Trabalhadores no Senado em dois mil e QUAtro... e é titular das Comissões de Educação... assuntos sociais... e Constituição e Justiça no Senado... e também pelo Partido dos Trabalhadores... o deputado Maurício Rands de PernamBUco... advogado... professor de direito constitucional... doutor pela Universidade de Oxford... e relator da reforma sindical... e é MEMbro da comissão que estuda a reforma política... e ex presidente da Comissão de Constituição e Justiça... pela oposição te::mos... o senador César BORges do PFL baiano... engenheiro... empresário... foi duas vezes governador da Bahia... relator do Estatuto do Desarmamento... é também autor da lei que permite a participação das FORças Armadas no combate ao CRIme organizado... também presente a deputada Denise FroSSArd do PPS do Rio de Janeiro... juÍza... ela ficou conhecida há quase dez anos... ao condenar toda a cúpula do crime organizado no Rio... é membro da Comissão de Constituição e Justiça da Câmara... e fundadora da ONG Transparência Brasil... dedicada a fiscalizar... e denunciar... casos de corrupção... e o deputado Gustado Fruet do PSDB Paraná... advoGAdo foi presidente da CPI do PROER... que investigou os escândalos financeiros... é membro do Conselho de Ética... e também da Comissão de Ciência e Tecnologia da Câmara federal... e foi relator da cassação do deputado André Luiz na Comissão de Ética... acompanha o nosso deBAte o cartunista Paulo Caruso registrando em seus desenhos... o flagrante... ou os flagrantes do programa... o Roda Viva é transmitido em rede nacional de TV para TOdo o Brasil... para particiPAR... o telefone é zero operadora onze três dois cinco dois... meia cinco dois cinco ou... o fax... três oito sete... quatro três quatro cinco quatro... e ainda o endereço do programa na internet... que é rodaviva@tvcultura.com.br... antes de iniciAR... eu gostaria de esclareCER... que eu vou usar o critério... que eu considero MAIS... CONsistente... para as atividades jornalísticas desse tipo que é o bom senso... ou seja... vou procurar dar o mesmo esPAço... para as duas bancadas... permitir o deBAte sem que isso vire... uma conversa incompreensível dentro de CAsa... e essa é a minha dificuldade... né?... fazer as duas coisas ao mesmo tempo... preservando a:: compreenSÃO... e a eqüidistância... em relação à questões tão GRAves e tão importantes... e eu queria comeÇAR...colocando em deBAte...eXAtamente as declarações que neste final de semana...éh:: aqueCEram o nosso tema... que foram... as declarações do Marcos Valério... dizendo que:: os empréstimos eram...paSSAdos ao PT... do PT para os deputa::dos... parlamentares... ele não citou deputados... e de outro lado... a do Delúbio Soares... confirmando isso....MAis ain::da... colocar nessa discussão... a entrevista que o presidente Lula deu para Globo na sexta-feira e foi no ar no Domingo...em que ele:: SEgue na mesma linha... a de que toda essa questão é uma questão do PARtido dos Trabalhadores...e não do governo e eu começaria... com a bancada do do governo Ideli Salvatti

I.S. boa noite a todos Markun boa noite a:: aos nossos:: colegas né do Parlamento da CPI... e dizer em primeiro lugar assim éh:: nós... temos essa questão do financiamento de campanha como algo:: ahn de fundamental importância colocado no cenário político brasileiro... e há muito tempo... né... essa é uma questão recorrente... toda vez que se:: investiga que se trabalha com a utilização da máquina pública... com a corrupção na máquina pública... a questão do financiamento aparece... aparece sempre de forma mui::to forte... e portanto quando esse assunto vem... ah:: para nós é de mui::ta responsabilidade... nós temos a capacidade de fazer a investigação... a confirmação... se ocorreu... quando ocorre... ah:: não só neste caso em todos os casos que ah tenha ah:: ocorrido né que a gente tem tem conhecimento... mas PRINcipalmente... eu acho que NESte momento... a nossa responsabilidade da investigação... e da punição... como o sistema legal vigente... de financiamento de campanha... mas que a gente possa ter a capacidade política de fazer a modificação... uma modificação que há muitos anos... nessa esPEra do Congresso Nacional... que efetivamente aprove a reforma política... 
que a gente POssa ter mecanismos mais eficientes... mais contundentes... de conTROle... né... dos gastos de campanha... da transparência de quem financia quem nas campanhas políticas... e principalmente que a gente POssa avançar para ah:: o sisTEma ah:: político eleitoral onde esta questão do financiamento tenha controle tenha transparência... e a gente possa ter PRINcipalmente... como nós defendemos... a questão do financiamento PÚblico com gastos limitados né... para que exatamente a:: democracia tenha o seu preço:: repartido e:: ( ) para toda população

C.B. olha as:: declarações que nós assistimos este final de semana parece ser algo que está concatenado... de um lado... o presidente da República...coloca sobre::...o financiamento de campanha um problema... por outro lado... o senhor Marcos Valério vem com sua terCEira versão... também dizendo até que o empréstimo foi pessoAL... e feito...ao senho::r Delúbio Soares... e não ao partido em determinado momento ele declara isso... e vem seu Delúbio Soares dizendo que como essa prática também é normal... então:: ficaria com relação ao financiamento de campanha a grande cul::pa dessa situação... eu acho que isso é uma cortina de fumaça... não é verdade... nós estamos num momento de averiGUAr com... PROfundidade ((tosses)) o porquê dessas questões... não é? efetivamente...aí... HÁ dinheiro público envolvido... não é um mero financiamento de campanha... que pode ser feito legalmente... existem práticas hoje no país... que SÃO acompanhadas pelos Tribunais Regionais Eleitorais... pelo Tribunal Superior Eleitoral... então nós não podemos imagiNAr... que através de escaPISmo...ou divergioNISmo... a população brasileira não vai identificar os culPA::dos...DEste momento que conquistaram esse cenário aqui tão bem representado um verdadeiro mar de LA::ma... a população está assistindo perplexa... essa situação... e quer averiguações profundas... eu acho que o presidente que declarou que não quer PEdra sobre pedra...o presidente que declarou... que quer efetivamente até cortar na própria CARne... ele tem que orientar até sua banCA::da na Comissão Parlamentar Mista de Inquéritos... para que tenha Essa disponibilidade... essa disposição...de esclarecer efetivamente todos os fatos... é isso que deseja... a opinião pública brasileira e não te/ ter ( ) e cortina de fumaça

M.R. eu penso que:: o que a sociedade quer... éh:: que o Brasil funcione...para o Brasil funcioNAR... para que:: as instituições do Estado... resolva os problemas da população... um dos GRANdes obsTÁculos...é::... o fenômeno da corrupção... e:: a sociedade quer Paulo que:: NEsse episódio...TOdos que cometeram irregularidades sejam puni::dos... o que a sociedade quer o que nós queremos...é que TOda a verDAde... seja trazida... para todos os brasileiros... e brasileiras... mas a sociedade quer um pouco MAis... ela quer que nós teNHAmos a capacidade de fazer as muDANças institucionais... SEjam aquelas do funcionamento da administração pública... sejam aquelas do funcionamento do sisTEma político...para que no fuTUro... esses problemas... esse mar de lama que nós estamos tentando aqui corriGIR... não seja reproduzido... eu VEjo nesse momento...quando o presidente Lula... dá aquela entrevista... ele:: evidentemente está fazendo o juízo de condenaÇÃO... ao funcionamento... DESte sistema político... ele está formulando uma CRÍtica no sentido de que:: há (reconhecido) que setores do Partido dos Trabalhadores... incoRREram... em algumas dessas práticas... e NEsse momento eu/ todos nós achamos até que... tem um lado positivo na crise que é... priMEiro...traZER a verdade para sociedade... seGUNdo... criar as condições para mudar as instituições inclusive o sistema eleitoral... e político partidário... e no CAso do PT... o PT rever os seus procedimentos... o PT está tendo a humildade... de apresentar as suas desCULpas a sociedade porque alGUNS... de seus membros... incorreram isso... então é momento TRISte... porque é uma crise...mas é um momento... alVIssareiro porque DEla podemos extrair transformações

P.M. Denise Frossard

D.F. pois é Markun... eu estava pensando aqui... com os olhos de quem viu... desfilar o crime na sua frente durante QUINze anos... eu estou vendo quem instruiu/ é como eu estivesse vendo o advoGAdo quem instruiu o réu chegou a minha presença... quem instruiu o DeLÚbio... foi o mesmo quem instruiu o Valério... e foi o mesmo que instruiu o presiDENte... isso faz portanto 
que o presidente entre no proCEsso... ONtem... eu levei uma tromBAda com isso... mas o presidente veio para dentro do proCEsso... o que o coloca na posição já de ser in-ves-ti-ga-do sim... ele TENta se livrar ele FAZ a a/ ele coloca a fala dele tentando se liVRAR jogando a BOMba no colo do PT... ele JOga... mas ao mesmo tempo... ele diz "eu trouxe de lá... os melhores quadros”... José Dirceu que foi o presidente do partido... mas ele coloca lá TRÊS ministros dele... se tirarmos Lula... que que é o PT? ab-so-lu-ta-men-te NAda... NAda... e ele coloca TRÊS ministros dele lá... esse é um fato Markun que ontem me deixou ab-so-lu-tamen-te perplexa diante da câmera... perPLExa... e que traz o presidente para a ce-na de ser inves-ti-ga-do agora sim... porque HOUve... e está em andaMENto... esTAva em andaMENto... e só foi cerceado... porque havia ( ) aí no meio e o Marinho... mas estava em andamento... uma capTUra do estado... uma quaDRIlha... para capturar o esta::do... uma quadrilha... inclusive com o lavador do dinheiro... não vão encontrar dinheiro não nos bolsos dos petistas não vão... havia um projeto de capturar o poder

\section{P.M. José Eduardo Cardozo}

J.E.C. eu não tenho dúvida... e acho que ninguém tem aqui... de que:: ãh os depoimentos transmitidos do Delúbio... e do Marcos Valério... têm grandes pontos obscuros... não se deixa claro quem decidiu fazer o caixa dois para onde foi o dinheiro... não fica claro a origem do dinheiro...

você concordasse eu acharia estranho

J.E.C. então é evidente que o nosso paPEL coletivo é investigar... agora... eu acho que algumas questões têm que ser colocadas com precisão... eu não vejo Denise vou discordar de você... como o presidente

D.F.

porque eu acho

não ((risos))... eu até me espantei com a sua contundência

D.F.

não porque ontem eu levei um SOco no estômago

J.E.C

não... e eu agora levei um...

porque eu confio no seu ( )... talvez eu esteja errado... mas o que ocorreu foi o seguinte Denise veja éh::... o presidente fez uma declaração... uma entrevista e o que disse o presidente? "Olha"/ se eu bem me lembro ele disse "olha o que acontece... no PT nas eleiÇÕES acontece com todo mundo" isso foi a frase mais contundente que ele utilizou... e aliás ele não precisou (ser) a caixa dois o que viria a ser et cetera... de onde se tira DISto... a idéia de que ele foi orienTAdo pelo mesmo advogado que orientou os dois?... eu não eu não acho

D.F.

180

criminal

\section{[}

eu imagino... da cabeça da juíza

J.E.C. $\quad[$

só um pouquinho... só só um pouquinho só/ não não mas sim é mas eu acho

\section{[}

M.R. é um salto lógico ((risos))

J.E.C é um salto lógico grande eu 
I.S. [

imaginação criativa

D.F. $\quad[$

190

finCAda nos fatos... calma senadora... finCAda nos fatos

J.E.C.

só tentar terminar ((risos)) estou tentando concluir...eu não vejo NIsso... uma uma/ de onde extrair a conclusão... o que não quer dizer que tudo deva ser investigado... não vejo neNHUM problema em tudo ser investigado... o governo tu::do... o nosso papel é Esse... aGOra... JÁ se coloCAR que o mesmo advogado orientou numa trama maquiavélica aliás... me permi/ me permita só agora tenha orientado MAL... né? porque o presidente não tinha o porquê de dar entrevista ontem

D.F. eu também acho

J.E.C. $\quad[$

então foi...se foi bom para um então PÉssimo advogado... PÉssimo colega

D.F.

positivamente com a cabeça))

eu acho ((afirma

J.E.C. não acho... não acho sinceramente... o presidente está distante dos fatos... a opinião pública inclusive reGIStra isso... e seria estranho uma orientação para que E::le dentro de sua lógica entrasse nos fatos... não não foi o que ele disse... nós não podemos tirar essa conclusão em hipótese nenhuma... MAS:: também acho outro dado éh:: senadora... eu não tenho a menor DÚvida que:: nós temos que punir TOdos... envolvidos... Todos... sem exceção... inclusive não teremos nenhum problema em dar punições seVEras em quem usa a estrela no peito... mas discuTIR hoje... financiamento eleitoral e reforma poLÍtica... não é uma cortina de fumaça... é combater as causas... porque a corrupção eleitoral NÃO começou com o PT no governo... éh vem muito antes... não podemos taPAR... não podemos tapar o sol com a peneira tamBÉM sobre esse assunto

((vozes sobrepostas))

\section{P.M. Gustavo Fruet}

G.F. boa noite Markun... são duas questões distintas que:: chamam a atenção... nesse episódio... uma é o resultado possível... DEssa investigação... reforma política e a forma de ocupação dos cargos do Estado... quebrar certos hábitos da cultura política brasileira... mas nós temos a questão principal que é a questão de fato e concreta que deu origem a isso tudo... uma disputa interna... DENtro do governo... que levou... para defesa... o deputado Roberto Jefferson há pouco mais de quarenta dias... provocou... a maior muDANça ministerial e PARtidária... principalmente do partido do governo até hoje registrada na história... do Brasil... nesses quarenta dias... o Brasil está se vendo diante de/das MAIS diferentes denúncias... e no fundo nós vamos ter que responder... não se TRAta simplesmente do chamado caixa dois... houve um financiamento ilegal de campanha... nós temos uma questão concreta... não é uma questão contável... é a utilização de recurso PÚblico NESte governo... pelo PT... que não pode comprometer a sua história... sempre a favor da ética... mas que sofre MUIto mais... porque adota uma prática.. proMÍScua... de ocupação de cargos no governo... havendo uma contra partida de financiamento eleitoral... não importa mais se é um financiamento de um real... ou de cem milhões de reais... a questão é que se está tentando trabalhar uma versão... restrinGIR a 
um fato isolado a duas pessoas... o Marcos Valério e ao Delúbio... tentando de alguma maneira... blindar... o presidente da República... blindar... a base aliada... e colocar isso como fato... isolado... é muito mais grave... e nós vamos ter que responder ao final... se é um canal comunicante... e qual o grau de participação do presidente da República... qual o grau de conhecimento do presidente da República... e principalmente das pessoas diretamente ligadas a ele... e em especial... o ex-ministro da casa civil

P.M. OK nós estamos quase no final do bloco mas antes eu queria:: mostrar aí uma algumas entrevistas que foram feitas... na cidade de São Paulo... com gente... da população... sobre essa questão que acho que levanta algumas questões... que certamente nós vamos debater no segundo bloco vamos ver

((filme))

P.M. pois é e essa pergunta vai ficar:: para o segundo bloco... quantas CPIS precisam ser criadas... se é que precisam ser criadas várias CPIs para discutir essa questão

((cenas de Roberto Jefferson na CPI e no programa Jô Soares))

((Segundo bloco do programa))

P.M. em várias situações éh...durante...os depoimentos...alguns integrantes da CPI tiveram...o comportamento questionado...OU porque...se dirigiram de forma...considerada ... desrespeiTOsa... aos depoentes ou porque... de alguma forma encaminharam perguntas que tinham... o objetivo... de DESqualificar os depoentes

((filme))

P.M. a minha pergunta é simples... se não está havendo hum:: ... ou se não esTAva havendo há bem pouco tempo atrás na CPI... essa tentativa de um lado de DESqualificação de certos depoentes e se outro lado de antecipação... da campanha eleitoral de dois mil e seis... e pergunto se não é SÉrio demais o assunto... para que a gente resvale para qualquer uma das atitudes... tanto... do lado da oposição de tentar POlitizar excessivamente o debate... como do lado do governo de tentar desqualificar... pessoas que têm feito denúncias GRA::vês... que emBOra...desqualificados alguns:: daqueles denunciantes... não... minimiza a questão e agora eu inVERto... a:: ordem e começo com César Borges

260 C.B. éh... efetivamente a:: Comissão Parlamentar Mista de Inquéritos não deve politizar as questões ... acho que nós devemos estar aBERtos para fazermos a investigação... dentro de/dos trâmites que uma investigação deve ser conduzida... entreTANto... muitas vezes nós temos assistido isso.. como é o caso da... Fernanda Karina... uma tentativa de desqualifica::-la... até entrando pela sua vida pessoal... eu acho isso... extremamente condeNÁvel... não devemos ir por aí... eu assisti o PT desqualificar Fernanda Karina e ao mesmo tempo fazer a defesa de Marcos Valério... e o Marcos Valério FOI para a Comissão Parlamentarista de Inquéritos com um habeas corpus... dado pelo Supremo Tribunal... assim como amanhã... irá o Silvio Pereira... depois de amanhã o Delúbio Soares... e lá então desrespeito completo e total... que se fará... à comissão... porque... eles vão responder o que querem... quando querem não respondem... 270 MENtem cinicamente... o Valério mentiu ele disse que só tinha um único aval... eu fiz essa pergunta diretamente a ele... ele disse que só tinha um único aval... de empréstimos... feitos ao PT... LOgo em seguida sai a versão de dois avais... agora aparece o Marcos Valério como aquele tomaDOR de recursos para o PT... recursos garantidos com o contra::to dos Correios... quer dizer ele mentiu... se ele for novamente com o habeas corpus vai voltar a mentir... claro que serve para amanhã... contradizê-lo mas de qualquer maneira é um desresPEIto à Comissão Parlamentar Mista de Inquéritos... eu conclamo que inclusive muitas vezes o Partido dos Trabalhadores... que deixa essa postura de desqualificar testemunhas... e procurem simplesmente fazer o trabalho de investigação... Abra efetivamente nesse momento... as suas enTRAnhas... para que nós possamos esclarecer para a nação... o que aconteceu inclusive com esse partido... importante partido da República brasileira 
J.E.C. eu acho que nós não podemos confundir as coisas... desqualifiCAR uma testemunha... é por exemplo... achincalhá::-la daquela forma... que até alguém do seu partido fez senador... eu acho que no caso da da Karina... comete-se uma injusTIça aqui... eu quero deixar claro bem claro qual é a injustiça... ninguém está dizendo... nem desqualificando... o que Karina faz de denúncia... aliás... sinceramente... muitas das coisas que ela falou... estão se comprovando (fatidicamente)... não é Isso... poRÉM o papel de Karina TEM que ser investigado NÃO para desqualificá-la... mas para saBER... até o nível ou o envolvimento se afirma... POR exemplo... aquilo o que eu ia ler... e não me deixaram ler era um bilhete que ela escrevia para o seu Marcos Valério... dizendo que a CONta banCÁria dela havia sido devaSSADA... por que ela tinha que informar alguém... que ela dizia que a oprimia... que a conta bancária dela estava devassada? será que ela pertencia ao esquema? será que ela opeROU o esquema? será que ela fez as denúncias porque teve algum interesse frustado ou havia algum outro interesse empresarial por trás DEla? bem... se isso não for objeto de investigação na CPI... me desculpem... éh... as circunstâncias que a entrevista foi dada... na medida que havia inclusive um pagamento de trezentos mil reais para um jornaLISta... que o próprio Marcos Valério diz que paGOU... para aquele que informou da entrevista... precisa ser esclareCIdo... faz parte... as Vezes... das disputas e a juíza responsável não vai negar Isso... quando muitas vezes éh a corrupção aFLOra... e se faz por brigas Entre... pessoas interessadas... NÃO do bem... mas as vezes pelo mal... se Karina não tem nenhum envolvimento com isso... Ótimo... nós a aplaudiremos naquilo que ela fez de bem para o país... mas:: isso não quer dizer que ela está iSENta de uma investigação até porque existem contradições como o deputado ( ) o seu partido em relação a outras pessoas mas para tentar buscar a verdade que CERca todo esse depoimento

P.M. quem Denise Frossard? ((acena afirmativamente com a cabeça))

D.F. éh... eu vou fazer uma observação aqui Markun...ah:: aquela comissão é uma coisa no::va pra mim a CPI... né... e eu observo que ali... éh se transita entre NERvos partidários expostos... e não deveri::a ... porque na soleira da PORta da CPI... deveria ficar as COres partidárias... e adentrar aquele reCINto do plenário... as pessoas que vão investiGAR... porque ali não está a questão de governo... é essa a minha tese... ali está a questão de Esta::do... nós não estamos ali porque um cheFEte... dos Correios...foi...surpreendido com a mão... na boti::ja... nós estamos ali porque um depuTA::do fedeRAl que tinha a responsabiliDAde... de conduzir um partido como o senhor presidente... DI::sse que era assi::m...então quer dizer éh... eu sei que é diFÍcil...mas tem que deixar as cores partidárias... porque...nós ali agimos como investigadores... e com poderes de juí::zes... portanto é I::sso que a democraCla brasileira ainda nã/ aí a democracia brasileira ainda não amadureceu a este ponto... então é por isso que nós tivemos quarenta e nove CPIs no SeNA:do... de mil novecentos e quarenta e seis à mil novecentos e oitenta e Nove... das quais apenas dezeSSEte... chegaram a ser votadas ter o seu relatório votado... e diz o autor disso... que é um velho... hum um aposentado... um funcionário aposentado... ele diz QUAN::do oposição e goVERno se sentem...AMbos atingidos...há uma força uma contra a OUtra... e aí é o que se diz termina em pizza... é isso que nós temos que avanÇAR... como investigadores... fica aqui a minha/ o meu desafio

P.M. perfeito... Ideli

I.S. Markun... eu queria colocar assim oh... quando a gente... diz e afirma que nós temos que investigar a tudo e a todos... eu acho que é esse o nosso papel... e inclusive deixar muito claro que... todas as hiPÓteses têm que ser averiguadas até as últimas conseqüências... então na linha que o Cardozo colocou... agora veja bem... ah nós iniciAmos a CPI... a partir daquele episódio lá do do cara botando dinheirinho no bolso... nos Correios... e veja bem tem algo que precisa ser esclarecido que estava passando desapercebido... por que nos Correios? ...o Correio é uma instituição... que movimenta... interesses Bllionários atualmente... inclusive um interesse que está passível... de ser quebrado o monopólio por uma decisão do Supremo Tribunal Eleitoral... que é o monopólio da entrega de de correspondências e encomendas... só para ter uma idéia... a questão por exemplo desse mercado cresCENte da entrega das compras 
feitas pela internet... tem uma perspectiva de um CURto espaço de tempo... movimentado em torno de cento e cinqüenta BIlhões ao ano... ao Ano aqui no Brasil... então ( ) não é muito à toa que isso tenha acontecido nos Correios nessa disputa ou seja... não me parece que algo tão simples entre uma me::ra disputa inclusive de esPAço político partidário dentro daquela instituição... porque nós temos situações de disputas que vêm do do último período... na questão do transporte aéreo postal... gravíssimo... estão aí os contratos entende? os problemas não estão nos contratos... a SkyMaster... que nós estamos investigando... não tem problema... SÓ agora... ela tem problema que vem já de disputas... entende? desde do desde ah né dos últimos anos do do governo anterior... a questão do correio Híbrido... entende? há uma muDAN::ça entende? na na interligação... da da questão da informática com a telecomunicações... que revoluciOna todo a a a modalidade de entrega né... da das correspondências... e das encomendas então tem muita coisa em disPUta... 345 ecoNÔmica...nesta... questão da corrupção que apareceu NOS Correios... coincidentemente NOS Correios...neste momento

\section{P.M. Gustavo}

G.F. CPI não pode ser fogueira de vaidade nem fogueira de inquisição... eventuais excessos serão... atropelados pelo resultado positivo ou não dela... nós seremos julgados muito mais pelo resultado que propriamente... por Erros desse excesso ( ) próprio de uma disputa poLÍtica... que nós temos que sepaRAR... o JOgo... político... entre oposição e situação... de um projeto maior de Estado... mas é bom lembrar... que agora teve uma fase da guerrilha e nós vamos na fase da qualificação... e tudo isso começou... a partir daquela gravação dos Correios... que levou Roberto Jefferson... a sentar... no Conselho de Ética... e ser proFUNdamente... ou sofrer uma tentativa profunda... de desqualificação... não é o bem contra o mal... não tem anjos nesta história... tem vítimas e cúmplices... e o Roberto Jefferson é bom lembrar... era da base do governo... e todas as denúncias que ele fez se referem à BAse do governo... há pessoas profundamente ligadas ao ministro José Dirceu... na busca de sustentação da BAse do governo no Congresso Nacional... e no apoio das eleições municipais...depois DEsse pronunciamento do Roberto Jefferson em que se tentou desqualificá-lo... apesar de muita resistência... foi instalada a CPMI dos Correios... e se tentou restringir o trabalho da CPMI dos Correios... em trinta dias... foi instalada mais de duas CPIs... dos Bingos... e CPI do Mensalão que deverá ser instalada amanhã... nós temos que evitar que essas... FREtes eVItem a convergência na investigação... e é bom destacar também... que nós estamos in/ investigando uma série de questões pontuais... mas não entrar na armadilha... deixar que CPI vai ser uma revanche... ou que Isso é uma prática comum... há muitos anos no Brasil... o governo... há dois anos e meio instalado... teve toda a oportunidade... de apontar desvios denúncias através da corregedoria da polícia federal e de sindicância... agora o FAZ... em função das CPIs que colocam em cheque... a serieDAde... da atual administração... então o importante é destacar... terminou a fase da guerrilha... ENtra na qualificação... mas é fundamental ter claREza... que a CPI será julgada e todos nós... muito mais pelo resultado... do que eventuais excessos

\section{P.M. Maurício}

M.R. os problemas que têm na apuração que é o que queremos fazer... eles são de duas ordens né... como você lembrou Markun... o priMEiro é o::/a tendência que algumas pessoas revelam de querer desqualificar o depoente... não é por aí... porque mesmo a pessoa que não tem credibilidade moral... ela pode naQUEle caso conCREto... estar dizendo a verdade... então cabe a nós... que estamos na função de investigar de perseguir todas as:: denúncias... todas as hipóteses... que são levantadas até por aquelas pessoas que não têm... digamos assim... essa credibilidade a priori... ((sinaliza aspas)) mas o segundo problema e eu vou citar aqui três exemplos... é o de transforMAR a Comissão Parlamentar Mista de Inquéritos para investigar a corrupção... em objeto de disputa política... em antecipação de palanque eleitoral... em querer... DAR versões... apenas para enfraquecer o seu adversário em dois mil e seis... vou dar TRÊS exemplos... de que isso aconteceu infelizmente... eu estou com o deputado de Estado Fruet eu acho que nós temos que agora exiGIR o Brasil eXIge Paulo... que nós deixamos essa 
400 P.M. OK... eu vou colocar a seguinte questão que é do telespectador Maurício ( ) da capital e que eu acho que coloca:: a questão se vamos investigar se o importante é investigar se não tem disputa política... "por que que o deputado José Dirceu não é convocado para depor nessa CPI?”

J.E.C. olha... eu que/ é importante é claro que eu acho... que a lógica de uma investigação ela tem que seguir um caminho muito reto e muito criterioso... nós cometemos um Erro... no modo de entender... quando nós chamamos naquele primeiro momento o Marcos Valério.... por que que nós cometemos o erro? porque as figuras que têm uma DENsidade informativa... só pode comparecer depois que você tem todos os dados nas mãos... é assim que se faz uma investigação... do ponto de vista CLÁssico... quando nós chamamos o Marcos Valério... seQUER nós tínhamos a movimentação financeira nas mãos... e nós inclusive éh:: chegamos internamente a falar... "olha chamar o Marcos Valério agora”... mas havia pressão política... e se NÓS do PT naquele momento falássemos... "não não vai chamar Marcos Valério" todos diriam... "NÃO o PT não quer investigar não quer o Marcos Valério” eu acho que aí

D.F.

J.E.C.

J.E.C. claro...por favor

D.F. o Eduardo tem razão sim é:: eu fiquei assustada né porque eu tenho o hábito de investigar também... com a quantiDAde de requerimentos... que não é a melhor forma... mas você tem que ter um FOco... quer dizer não é a quantiDAde de requerimentos e vamos ouvir todo mundo... ou vamos trazer tudo... porque eu me lembro José Eduardo talvez você se lembre... da CPI dos (Anúncios e dos Orçamentos) que produziu um QUARto cheio de documentos... que sequer foram oLHAdos

D.F. você tem que saber em primeiro lugar o que vai pedir a instituição pública...porque senão a instituição pública... ela manda aquilo tudo

J.E.C. e você não não/ separa as coisas

D.F.

você depois não processa aquilo... então é preciso saBER essa técnica 
seja... não... eu concordo plenamente com a Denise

ou

D.F.

obrigado pelo::/a parte

435

J.E.C.

REgra... e MÉtodo

não perfeito... investigação tem que ter FOco...

I.S. eu vou eu só vou pedir para que ela faça essa ponderação quando... a Heloísa Helena me critica... por causa da ló::gica... porque eu ((risos)) sempre peço a ló::gica que a gente tenha

J.E.C.

\section{[}

está totalmente correta olha

I.S. (volta) que a gente tenha método tá... só peço essa coisa tá ((sorrindo para Denise))

J.E.C.

só concluindo... em quinze segundos... o ministro José Dirceu obviamente terá que prestar depoimento... não há DÚvida nenhuma... ele fará isso... terá que fazer... e já disse que:: que irá... agora... isso na hora que nós tivermos todo um conjunto de informações que perMIta a ele evidentemente ah (tecer) as considerações elucidativas que devem ( )

P.M.

\section{[}

450

eu não vou fazer a rodada... a menos que alguém queira acrescentar alguma questão funda/ fundamental sempre que eu achar que é necessário porque senão nós vamos cada rodada... nós não vamos terminar o programa a salvo com um a um uma passada de bola por cada um... se alguém tiver alguma questão ( ) por favor

C.B.

\section{[}

455

eu queria falar sobre esse assunto... porque éh:: este é o discurso... que o PT tem adotado... mas no FUNdo... no fundo... quando nós vamos averiguar há um desejo claro e nítido... de que... os trabalhos não avancem no ritmo desejado

J.E.C.

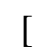

não é verdade

460 C.B. eu tenho chamo isso de uma ( )

J.E.C.

não é verdade

C.B. não... efetivamente... foi uma CPI chapa bran::ca... porque o Delcídio Amaral é o lí::der do PT no senado federal que é o presidente da CPI

J.E.C.

está sendo parcial ( )

C.B. MAS...os trabalhos não têm avançado no ritmo desejado

J.E.C.

o presidente da assembléia não 
C.B.

essa CPI não TEM gerado notícias nem fatos... nós corremos atrás dos fatos... que a impren::sa

I.S.

475

M.R. o sigilo já foi quebrado

C.B. mas não chegaram

M.R. mas ele já foi quebrado

C.B. não chegaram

J.E.C. $\quad[$ votados

I.S. 485

M.R. [

seSSENta pessoas convocadas lá nós temos mais de

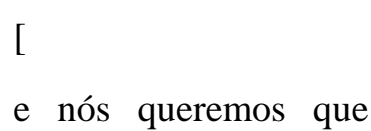
seja votado até para que o PT POssa se (desnudar)... e dizer que não quer a convocação de A ou de $\mathrm{B}$ ou de $\mathrm{C}$ então... ele JOga para adiante procrastina... no sentido de esperar até fatos que podem ser benéficos... felizmente para a nação... os fatos estão vindo aí e mostrando... o que que está havendo... enTÃO... a CPI NÃO tem atendido... ela tem sido burocratiZAda... e andando lentamente... vou lhe dar um exemplo... nós não temos ainda queBRAdo... o sigilo fiscal do senhor Marcos Valério a nível de ter anulado os documentos do Banco CenTRAL

mas a CPI não é para gerar fatos... ela é

temos lá uma cenTEna de requerimentos... muitos aproveitados no início da CPI... que dizer que foram votados então até o momento... ou há um consenso... e consenso significa dizer que o $\mathrm{PT}$ está de aCORdo... senão não há consenso... ou os requerimentos não são

a CPI é para investigar

o jornalismo investigatório está (andando) muito a (frente) atrás dos fatos... então nós

D.F. a comissão pode fazer o busca e a apreensão

observe... esses sigilos já foram quebrados... os documentos estão chegando... houve depoimentos... que foram precipiTAdos... porque eles não tinham chegado o documento... esse exemplo de Marcos Valério é apenas um exemplo emblemático... e nós vimos na fala do meu querido amigo senador César Borges... exatamente a confirmação do que eu estava dizendo... é que é... a tentativa de dar uma versão... de fazer a disputa polí::tica... quando nós estamos lá... aprovando os requerimentos... DENtro do que a senadora Ideli Salvatti disse... dentro de uma ló::gica... investigativa... e podemos citar dois exemplos que foram... utilizados... por PARte da bancada da oposição... para fazer mero proselitismo... foi aquele da:: QUEbra... do sigilo... do ex ministro José Dirceu... ou do ex presidente Zé/ José Genuíno... e dos outros dois... 
dirigentes... o PT se antecipou... E::les se anteciparam... DE::ram... a sua autorização para a quebra do sigilo... e a::pesar disso... DOis... três dias depois... ainda tinha alguns:: deputados e senadores infelizmente... da bancada da oposição... diZEN::do que NÓS... os deputados da bancada governista estavam lá... eviTANdo

I.S.

$$
[
$$

não queríamos... não queríamos

M.R. que fosse quebrado o sigilo... sendo que já havia sido autorizado... um outro exemplo

I.S. gastando HO::rãs... inclusive ho::ras

M.R. gastando horas... e aí quando nós queríamos nesse exemplo só para concluir senador... neste exemplo... neste exemplo... nós tínhamos formulado... olha... neste exemplo... nós tínhamos formulado... senador... este exemplo é emblemático senador... este exemplo é emblemático... porque naQUEle dia... nós tínhamos entregado na mesa do presidente Delcídio... um requerimento... fazendo convocações para depoimentos... dentro de uma LÓ::gica investigativa e não... a Cena... da disputa política... e aí... houve o quê?... houve deputados e senadores que ficaram insisTINdo... três quatro dias depois do sigilo já ter sido autorizado... ficaram fazendo versão... ficaram fazendo discurso... dizendo que nós não queríamos quebrar sigilos... que já estavam quebrados... então o que eu quero dizer... que a gente tire as liÇÕES... DIsso que aconteceu... nesse primeiro momento... A::pesar disso... a CPI avançou muito porque foram muitos depoimentos... foram cerca de quatorze depoimentos... muitos até com quatorze horas de duração... ela avançou... apeSAR:: de alguns setores da CPMI es/ éh estarem querendo fazer disputa política... eu acho que agora... a sociedade já repudiou isso e espero que todos nós tenhamos a Maturidade... para deixar essa primeira Fase... já ultrapassada... e que agora nós entremos de-fi-ni-ti-va-men-te... cruzar documentos... e fazer os depoimentos que são neceSSÁrios para esclarecer... a verDAde... é o que nós da CPMI queremos... o que é que o povo brasileiro quer... mais que isso Paulo Markun... nós estamos num momento agora que não é só para ficar dividindo... bancada do governo bancada da oposição... ou vice-versa... é para fazer bancada de quem quer investiGAR... e quem quer fazer disputa política

G.F. Markun... só duas observações... primeiro... a gente não pode ter receio da disputa política... nós temos que entender que não é um processo que haja neutralidade ideológica... o que a gente não pode... é confundir a disputa política... com o jogo menor... eleitoreiro... de curto prazo... nós temos que ter clareza... que há efetivamente uma disputa política... é um processo político a CPI não é um processo criminal... isso caberá depois ao Ministério Público tanto que amanhã... nós estamos pedindo uma força tarefa... porque o depoimento do Marcos Valério teve importância... para mostrar que ele fez afirmação falsa... desrespeitou... desconsiderou... e mentiu... para a CPI... no caso da QUEbra do sigilo... havia uma preocupação de ordem legal... o sigilo não é algo disponível que uma pessoa simplesmente abre e procura de espontânea vontade... nós estamos falando em documentos Públicos indisponíveis... nós estamos falando em transferência de dados sigilosos... então por precaução havia uma cautela... para que se houvesse a QUEbra de sigilo bancário fiscal e telefônico... para que não se alegue depois... nulidade no procedimento... e com relação a convocação do ex-ministro José Dirceu... efetivamente é questão de tempo apesar de toda resistência... principalmente... quando nós conseguirmos colocar... frente a frente... o ex-ministro José Dirceu... com o deputado Roberto Jefferson... esse parece ser o desejo de:: DE muita gente... para... efetivamente confrontar... as posições... que levaram essa crise no país

P.M. temos aqui uma parte da Denise para o para o

G.F. não consegui perceber e depois ((risos))

D.F. 
obrigada Maurício

I.S. se você me permitir também

P.M. vamos tentar

565 D.F. uma coisa... o Rands disse uma coisa ali que é é real... a a CPI... caminhou em alguns pontos... um deles... foi mostrar um desenho curiosíssimo... que é a captura dos cargos... que foi dita aqui pelo Cardozo pel/ pela Ideli... que dizer por que que um parTIdo ou um político ele quer um CARgo nos Correios?... será que as CARtas não estão chegando a tempo? os teleGRAmas estão atrasados?

570

((risos))

M.R. os selos não estão colando? ((risos))

D.F. ( ) então os SElos? tem problemas com os SElos?... será que é isso? ... NÃO... não é porque daquele::... e Roberto Jefferson deixa claro... porque daquele cargo ele faz o dinhe::iro... ele financia a SI... e aos SEUS é aLI... aLI naquele cargo...QUANTO VAI?... agora... por que que isso ocorre? porque aqui no Brasil nós temos... CARgos por indicação... isso fica muito CLAro na CPI... nós temos a chance de refazer o serviço público na CPI... dezeNOve mil duzentos e dois cargos de indicação Markun... enquanto nos Estados Unidos são setecentos e um cargos por indicação... sem necessidade de concurso... enquanto na França são quatrocentos e cinqüenta... e no Reino Unido cen::to e (vinte)... com dezenove mil duzentos e dois cargos... nós vamos ter a capTUra do esTAdo... e essa... e essa corrupÇÃO generalizada que no caso se serviu... e aí é um convencimento ME::u... de acordo com o caminhar das provas... por essa captura do poder num proJE::to... de uma ditadura com apaRÊNcia... de democracia a LA CHAves... aí era isso que se pretendia

M.R.

não

D.F. não por Todos... Maurício... não por Todos... FUI engaNAda... provavelmente vocês também foram... agora uma Cúpula... pretende isso SIM... está muito CLAro para mim... depois do/ da fala do presidente ontem

P.M. Maurício tinha uma observação?

M.R. é rapidamente na fala de Gustavo Fruet... depois eu gostaria no tempo normal... comentar a observação da minha querida Denise Frossard... Gustavo ali naquele episódio... a CMPI tem... os poderes jurisdicionais... o oFÍ::cio... que saiu do presidente Delcídio... ele tem... a força... de uma decisão judicial... exiGINdo a transferência daquele sigilo... e os requerimentos... dos quatro... que estavam tendo que estavam autorizando aqueles sigilos... tinham sido reformulados no curso da semana nos TERmos... recomendados... pela assessoria jurídica... da CPMI... ali ficou um exemplo CLA::ro... de tentativa... de mero utilização política... é como você diz... a disputa eleitoreira... a peQUEna disputa... não é a disputa política de iDÉias... de concepção de Estado... essa nós temos que fazer sempre... estamos fazendo Aqui... mas a eleitoreira... ficou ali paTENte... naquele episódio

P.M. Ideli

I.S. Markun só assim oh... em cima um pouco no que a Denise falou...mas assim... eu volto a a frisar a questão da disputa dos grupos econômicos... porque assim... quando fala de ( ) a máquina estatal pel/ pelo partido pelo cargo... mas tem uma captaÇÃO da má::quina estatal pelos intere::sses econômicos... eu tive inclusive a oportunidade na CPI de perguntar... ao ao ForTUna... que tem uma empresa de duzentos mil ah... um capital de duzentos mil... por que QUE ele com uma empreSI::nha ta... ele se associava a gru::pos... inclusive mul::tinacionais... para... participar de licitação da máquina pública brasileira?... por que que uma mul::tinacional... que detém quaren::ta por cento do mercado... precisa de uma empresa de 
duzentos conto... para participar da licitação? porque essa emPREsa... ela detém... uma TECnologi::a de... influir na máquina pública... através... do grampo... através da filmagem... através da da chantagem... através do ( )... através... de mecanismos que esTÃo colocados vicia::dos entende? dentro da máquina pública há MUito tempo... isso ficou viSÍvel... e nós temos que investigar tamBÉM isso... a disputa econômica... o aparelhamen::to da máquina estatal em benefícios de GRANdes grupos econômicos... e não apenas somente determinadas questões que a oposição quer investigar a oposição parece que agora foCOU... uma... situação... nós queremos investigar o financiamento de campanha... a participação de peTIStas em qualquer ato ilícito... nós queremos investigar também... o aparelhamento da máquina pública para os grupos econô::micos... a questão da/ dos cargos... nós queremos investigar TUdo e todos

620 J.E.C. rapidamente Markun... eu acho que é importante deixar claro ao telespectador... que essa divisão entre governista e oposição nem sempre ela tem uma ( ) nítido... por exemplo eu tenho uma gran::de concordância com um par da análise feita DA/pela juíza Denise Frossard... essa idéia dos cargos de confiança que é uma (realidade) não só da União... mas do meu estado do estado do senador César Borges da Bahi::a... do Rio de Janeiro... e da captu/

D.F.

Ih:: do Rio de Janeiro

é um horror

J.E.C é histórica no Rio de Janeiro... ela é histórica aqui no Brasil e

D.F.

$$
\text { e na... segurança pública e ( ) }
$$

J.E.C. nós temos que combater isto... e e e englobar o esTAdo

D.F.

é um hoRROR

J.E.C. e e e talvez tenha razão aí o Maurício Rands... a crise talvez venha para o bem se a gente sairmos disso... aqui é a minha concordância... mas a minha discordância é com o senador César Borges senaDOR C-P-I não cria FAtos... CPI desCObre fatos... e pro::va... que bom se se nós não criarmos nenhum FAto... aplausos para nós... por que? porque nós estamos segundo o cami::nho... da Investigação... Esse é o nosso propósito... e a finalidade da nossa ação

I.S. FAto igual o Maia fez

P.M.

antes da gente....antes da gente... passar para o intervalo... eu queria:: mostrar... mais... algumas... entrevistas... que foram feitas na cidade de São Paulo que mostra um pouco da opinião... da população sobre essa questão... vamos lá

(( filme que mostra algumas pessoas opinando sobre a crise))

((em seguida cenas do depoimento de Roberto Jefferson na CPI e em uma entrevista no programa Jô Soares. Em uma das cenas é apresentada a acusação que Roberto Jefferson fez à Ideli Salvatti e a resposta dela na CPMI dizendo que ele não tinha provas. Após o filme, a câmera foca no mar de lama reproduzido no meio do cenário))

((terceiro bloco do programa))

P.M. sabe o que eu acho DIsso? eu acho o seguinte... a minha dúvida é se esse baRRAco... resolve a questão... por quê?... porque as acusações que o Roberto Jefferson fez... não fez uma vez só não... fez várias... são gene::ricas... elas atingem todos vocês... eu digo a você porque eu não 
sou nem deputado nem senador... e eu acho que o GRAve... é que se essa CPI não aPU::ra as coisas de verdade... e não se descobre o que há por trás disso... as acusações ficarão... e o baRRAco passa... então é essa a questão que eu queria colocar

I.S.

por isso Markun que no caso... o (princípio) da minha pessoa... que me senti proFUNdamente... atingida... pela aquela nota né... redigida com sentido:: eu não diria dúbio né... porque ali tinha quinta sexta sétima intenção né... na na forma como foi redigida... eu ah... "rodei a baiana” né... segundo o César Borges aqui né

C.B.

((risos))

665

I.S. então... né... mas não só roDEI a baiana... eu estou proceSSANdo o senhor... ah Roberto Jefferson... eu entrei com TRÊS interpelações judiciais... inclusive o PRA::zo encerrava hoje... vou entrar né... na sequência

D.F. [

a redação ficou confu::as... se me permite... a redação é que ficou confusa

I.S.

mas a redação foi proposiTAL para criar confusão... e era para exatamente... era um disse mas eu não disse... entende como como ele teve a ousadia

M.R. [

mas foi proposital Denise... a ambigüidade foi proposital... foi muito bem bem pensado

D.F. [ mas para mim ficou muito claro (que ele) disse

I.S.

não a ou::sadia... a cara de Pau... de dizer que no César/ no Jô Soares... ele não não acusou... os integrantes da CPMI

M.R.

ele já atacou se defendendo

I.S. ele acusou... li-te-ral-men-te... TO::dos os... integrantes da CPMI... Todos... TOdos

D.F.

M.R.

sobre isso daqui viu Denise... eu gostaria de dizer sobre isso daí... duas considerações que eu não vi no debate... quando ele faz aquela coisa generalizada estava na hora de ele falar... alguns de nós fizemos a gesticulação... mas nós não íamos interromper... aí depois não todo mundo concordou... não concordamos... vou dizer MAis Paulo... eu estava tanto Deni/ 
I.S. horário da interpelação a primeira coisa que eu falei foi a seguinte... "aqui ninguém está em disputa e nem discussão de quem é melhor do que:: do que:: o outro... a diferença é que o seNHOR está aí sentado como acusado... e NÓS estamos sentados aqui como pessoas que estão investigando"

M.R.

700

rapidinho eu (concluo)

Ideli viu viu só bem

C.B.

eu vou pedir ( )

pela ordem eu gostaria de ( ) que a bancada do ( ) está usando muito tempo eu gostaria de usar um pouco Markun é o seguinte... fazer um pouco de história

P.M.

volta

[

por favor éh depois ( )

C.B. é porque... senão vejamos... o Roberto Jefferson foi defendido pelo presidente da República... que o chamou de parCEIro... disse que daria a ele um cheque em BRANco... logo depois ele evolui essa posição... e vai CONtra a instalação da CPMI dos Correios... jogou toda a bancada... e que eu acho que:: não sei quem assinou a CPMI dos Correios... mas não assinaram por determinação do governo... não iria ter CPMI dos Correios se dependesse do governo mas aí veio as declarações do senhor Roberto Jefferson... aí ficou inexorável a implantação da CPMI... e foi implantada... e aí havia um acordo que SEMpre... haveria uma divisão entre situação e oposição para compor a mesa diretora... a oposição indicaria o relator... e a situação o presidente... não aceiTAram... fizeram o que nós chamamos numa época de... mesa diretora chapa branca... agora veja bem o que que aconteceu só para concluir há uma convergência há uma convergência na lógica do Roberto Jefferson com a lógica da defesa do governo por quê? porque AMbos querem envolver a todos... o governo agora diz... que... financiamento de campanha... é algo que TOdos os partidos... trabalham com caixa dois... está muito próximo ontem um artigo do Roberto Jefferson que diz quase a mesma coisa no jornal... Folha de São Paulo está convergindo né... a defesa de ambos pelo ( ) público

D.F.

$$
\text { [ }
$$

vendeu

agora senador...senador... quanta gente passou pela máquina pública e NÃO se

C.B.

[

CLA::ro mas é claro nós (checamos) isso

D.F.<smiles>[AlH2]</smiles>

é isso que precisa ficar claro

C.B. a investigação cai sobre aQUEles que têm acusação... e ( ) mais uma vez está querendo dispersar a opinião pública dizendo... não “TOdos fazem isso"... não é verDAde... nós refutamos a denúncia recai sobre o PT... sobre senhor Delúbio Soares que diz que praticou o caixa dois... ele é um réu confesso assim como o Roberto Jefferson também é réu confesso e diz que recebeu quatro milhões do PT... então veja como há convergência da defesa do Roberto Jefferson com a defesa do PT esse é o PONto

D.F. 
agora quando o Delúbio... só um minuto quando o Delúbio diz que ele não contabilizava e era o caixa dois... eu me lembro que a gente tem aLI... éh éh antigamente se fazia aquela coluna débito crédito... então na coluna do débito deve estar lá quatro milhões para o deputado Roberto Jefferson... que ele diz que recebeu... do PT... mas recebeu por fora... até hoje não tem o dinheiro... e o Delúbio diz isso... então no DÉbito do caixa dois... tem que ter lá os quatro milhões... do Roberto Jefferson

J.E.C.

que o Markun tem toda razão em uma questão

( ) em primeiro lugar eu acho

P.M.

$$
\text { ele vai depois }
$$

J.E.C. então o Markun tem toda razão numa questão... em primeiro lugar essa CPI não pode acabar em pizza em hipótese nenhuma... ou seja a gente tem que ir nas últimas conseqüências... na investigação na punição/ na apuração na punição... segundo... não pode acabar em pizza porque há um problema claramente estrutural... que tem a ver com a proMíScua relação de financiamento ( ) eleitoral no país... não é de hoje senador César Borges aí... eu mais uma vez eu vou (discordar) com vossa excelência

755 C.B. o senhor está sendo escaPISta

D.F.

financiamento viu

olha eu quero uma parte dessa discussão

J.E.C. não estou sen/ olha... ( ) eu até comecei pelo inverso... tem que puNIR... tem que pegar todo mundo que tiver do PT tem que colocar na cadê::ia... está claro senador?... está claro... vamos separar isso... outra coisa não DÁ para dizer... que SUbitamente o Brasil acordou com uma revelação de que há caixa dois... em campanha eleitoral... com fala do senhor Delúbio... me desCULpe

C.B. estou vendo o Roberto Jefferson falar

765 J.E.C. antes de Roberto Jefferson... antes de Roberto Jefferson senador... já há muitas denúncias

C.B.

a mesma idéia de Roberto Jefferson

I.S.

alguns aqui... em dois mi::l noventa e se::is noventa em oito

eu posso até ler

J.E.C.

falar senador... ou SEja

noventa e seis... dois mil... nós podemos até

C.B.

\section{[}

dois mil e dois... a campanha do presidente Lu::la

J.E.C. senador César Borges... estou falando que existiu hoje uma afirmação do tesoureiro do PT... mas não tem que dizer que nunca ninguém do PFL... nunca ninguém... dos outros partidos trabalhou com caixa dois... (perdoe) César Borges... vamos ser TRANSparentes com a opinião pública... não é ho::ra... de nós termos ((sobreposição de vozes)) 
provar o caso do PT ...e não do PFL

(essa é sua conclusão não é a minha) você tem que

J.E.C.

eu vou lhe dizer que a

Comissão de Justiça no deBAte de reforma política... VÁrios deputados faLAram... VÁrios deputados falaram... e o deputado Rands é testemunha... que nós tínhamos que aprovar uma reforma política... para acaBAR com a hipocriSIa desse sistema eleitoral e da (falta) de financiamento... inclusive GENte muito correta... do seu partido

C.B.

\section{[}

790

isso é cortina de fumaça... a questão é investigar... agora (quem) está passando o caixa dois e não querer... fazer... de um produto que nós vamos tirar da CPMI já no caminho da investigação

J.E.C.

você tem receio de combater você tem receio de combater essa questão

C.B.

senador? por que que o senhor tem tanto receio de combater essa questão cultural?

usar a reforma política foi uma estratégia adotada pelo governo ( ) vou tratar de reforma política ( ) o governo nunca se interessou em dois anos e meio em reforma política

J.E.C.

posso inverter senador?... posso inverter?

$$
\text { posso...posso inverter senador? }
$$

C.B. se interessou muito em um momento por quê? para desviar a atenção

J.E.C.

posso inverter senador? por que o senhor tem? por que o senhor tem TANto receio que/ de sair fora da questão do PT... que eu acho que tem que apurar punir et cetera... e não quer discutir a questão global? por quê?

C.B.

para evitar que os senhores SAiam da questão do

810

PT

J.E.C.

$$
\text { [ }
$$

mas não vamos sair

C.B.

essa questão ((sobreposição de vozes))

815 J.E.C.

nós queremos é apurar e punir

((sobreposição de vozes))

M.R. eu acho que nenhum partido 
((sobreposição de vozes))

820

C.B.

passado ( )

M.R. [

830

I.S.

é a terceira

não vamos avante? Vamos avante? SenaDOR... senaDOR ((sobreposição de vozes)) vamos avante... senaDOR... e este partido... foi o primeiro partido... de todos da CPI

M.R. e até peço... eu desafio seu partido para fazer o que Partido dos Trabalhadores fez na CPMI

D.F. $\quad[$

\section{Maurício}

M.R. esponTAneamente... deputada um minutinho só... esponTAneamente quebro/ fez a quebra de sigilo... do parti::do... es-pon-ta-nea-men-TE

840

C.B.

M.R. agora... agora senador... vamos acabar... olha senador... vamos acabar com essa hipocrisia de dizer que "ah:: eu estou descobrindo ago::ra... que HÁ... recursos de campanha que não são escriturados" meu Deus... o estado brasileiro já dizia Raimundo ( ) é um estado patrimonialis::TA... e que uma minoria... historicamente já se apropriou deste esta::do... em que esta minoria reproduziu isso... num sistema poli::tico e que as eleições no Brasil... TOdos os brasileiros sabem... são feitas... sem que tudo seja descrimiNAdo

C.B.

inclusive pelo PT

850

M.R. e aí o que que nós queremos dizer?

C.B.

isso é réu confesso...admite isso agora não admitiu no

passado... admite agora

M.R.
[

isso nós não vamos/ não... um miNUto... um miNUto o que nós queremos dizer aqui... o que nós queremos dizer... quando nós chegamos aqui no Congresso Nacional primeira banDEIra... fazer reforma polí::tica... para atacar o problema do financiamento das camPAnhas... porque já haVÍamos... já havíamos Denise 
fazer uma pergunta? uma pergunta

posso fazer uma pergunta? posso

C.B.

M.R. Denise eu vou concluir... eu vou concluir senador... porque já haVÍamos... já haVÍamos que mesmo

J.E.C.

senador ( )

\section{[}

você já concluiu

M.R. senaDOR... nós já haVÍamos

C.B.

\section{( ) porque o deputado Ronaldo Caiado já apresentou ( )}

M.R. eu quero saBER... eu quero saBER... por que é que por que... é que alguns setores do PFL que ANtes de defenderem a reforma política... já estão dizendo agora... "não não quero mais fazer a reforma polí::tica... vamos esquecer outro momento" parece que quer o quê?... que o Brasil continue assim? é por isso que os senhores... é/rejeitam todas as mudanças que querem ser feitas

C.B.

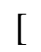

( ) súbitos interesses de reforma política

M.R. porque os senhores... estão aí com uma bancada de réu de responder... e induzir ( ) na campanha eleitoral de dois mil e dois de há muito tempo inclusive... que o PT vem (abordando) essas práticas... tem o caso do Santander ( ) tem a CPMI dos Bingos ( )

súbitos interesses NÃO... senador... quando eu era... senaDOR... eu era presiden::te da Comissão de Constituição e Justiça sabe o que que eu fiz? Quando... senador... eu era presidente... da Comissão de Constituição e Justiça... quando eu estava quando eu estava na presiDÊNcia da (CCJ) sabe qual foi a matéria que eu elegi como prioriDAde além da reforma do processo da justiça ser mais rápida para o brasileiro? foi a reforma política está aqui... o deputado José Eduardo Cardozo... que trabalhou muito nesse processo de articulação... deputada Denise Frossard estava na comissão... e aí o que que nós fizemos? realizamos as audiências públicas... encerramos TOdo o processo de consulta da socieDAde... dePOIS... fizemos o processo de discussão inTERna na comissão encerramos

D.F.

$$
\text { é verdade }
$$

895 M.R. todo o processo de discussão... não é verdade deputada Denise Frossard? Quando chegou na hora da votaÇÃO... aí requerimento porque o projeto não é ideal... aí sempre um arguMENto

D.F.

agora Rands

M.R. de quem não quer corriGIR... o atual estado de coisas

C.B. 
vocês TÊM maioria... porque inclusive o mensalão ajudou construir a maioria da Câmara dos deputados... então poderia ter votado se tivesse o desejo ( )

M.R.

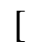

Senador... se o seu mensaLÃO... e esse tal mensalão... tivesse dado maioria... por que é que o governo perDEU... a presidência da CÂmara? por que é que o governo perdeu a eleição para o tribunal de contas se tivesse ( ) senador?

C.B.

\section{[}

perdeu porque não estava pagando... o mensalão segundo o Roberto Jefferson

M.R. [

não bate

C.B. é porque não estava mais pagando o mensalão... e aí perderam o controle aí da base do governo

M.R.

as suas idéias não estão batendo com os fatos senador

915 ((sobreposição de vozes))

I.S. Markun você pediu para aquecer... agora fala todos ao mesmo tempo e o telespectador não ouve

P.M. eu vou tentar botar ((muitos continuam a falar ao mesmo tempo)) ( ) Denise sen/ Denise Frossard por favor

D.F.

você me responda... me responda... eu estou ouvindo vocês dizendo aí e eu estou falando aqui como juíza eleitoral que fui a vida toda... há uma prática... de se esconder da justiça eleitoral o que acontece... realmente eu estou perPLExa diante do que se passa

M.R.

corrigir

e temos que

D.F. de todo mundo dizendo que isso é natural... não... NÃO... é natural

M.R.

mas tem que ser corrigido

930 D.F. não é natural

M.R. [

isto é claro é regular

D.F.

é uma PRÁtica de querer/ agora eu vou perguntar o seguinte... NESte momento trazer uma hipotética financiamento de campanha vamos fazer isso aqui aquilo outro... eu faço a pergunta a vocês que são políticos antigos... fosse outro sistema político... a la-dro-a-gem não aconteceria? CLAro que aconteceria... ela aconteceria porque a captura do Estado se dá por estes dezeNOve mil duzentos e dois CARgos de (preenchimento) ((mostra um papel com os dados relatados)) 
940

M.R.

agora são duas coisas

D.F.

J.E.C.

que existiam quando o senhor goverNAva... e que vai existir também... se não forem mudadas... quando o senhor vol/ voltará/ voltar a governar se é que isso vai acontecer

C.B.

M.R.

não só um momento... você já usou a palavra... deixe-me completar meu raciocício eu nã/ não vou monopolizar a palavra... vou apenas completar a minha perplexidade aqui... estou fazendo uma pergunta... fosse qual fosse o sistema político... nós estamos faLANdo... de... uma ladroagem... e aí eu me lembro do Chico Aní::sio... aí eu me lembro do Chico Aní::sio que disse o seguinte uma vez ele viajava de avião ao lado de uma moça muito bonita... e ele disse assim... "a senhora iria para cama comigo por um milhão?”... ela disse "sim claro" e ele disse "bom mas eu não tenho um milhão a senhora iria por cem?" ela disse "mas o senhor está pensando que eu sou prostituta?" ele disse "não essa primeira proposta já ficou decidida lá trás agora é uma questão de preço”... ((risos)) assim tamBÉM a a é questão dos ladrões do EsTAdo... é apenas uma questão de preço

J.E.C.

Denise então só só retomando aquilo que eu ia falar... veja só...éh senador César Borges... hoje no jornal eu acho que é a Folha de São Paulo... há uma declaração do miNIStro do TSE... falando "HÁ caixa dois nas eleições... mas infelizmente nós não temos como coibir”... ou seja é uma realidade TÃO noTÓria que até um juiz respeitado reconhece... portanto pare::ce

I.S.

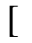

J.E.C. parece senador... que a memória... de seu partido começou dois anos para cá... DESde que eu me lembro por gente as pessoas que integram o PFL estão no poDER neste país... aliás o PFL só deixou de ser poder agora recentemente... e no entanto curiosamente... dentro do seu raciocínio dentro de sua análise parece que a corrupção nasCEU agora... surgiu agora... e TUdo se concentra agora... ANtes está TUdo perfeito... e depois que o PT deixar o poder está tudo perfeito... não é verdade senador... nós temos que punir quem do PT está envolvido nisso... e nós temos que atacar as CAUsas... esTRUturais que levam a essa realidade

C.B.

(quando) partido político tomou empréstimos (de empresas privadas) neste país quando aconteceu isso?

[

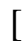

( ) usaram a empresa de publicidade do senhor Marcos Valério para tomar... quarenta milhões de reais... qual partido político já aconteceu na história brasileira?... dê um exemplo só

$$
\text { senador... senador... eu quero só saber }
$$

J.E.C. 
C.B.

$$
\text { não (não) apoiava }
$$

985 J.E.C.

não apoiava o Collor?... o presidente do seu parTIdo Jorge Bornhausen era miNIStro do Collor não era?

C.B. [

990

( ) veja tomou emprestado de uma empresa tomou emprestado de uma empresa que tinha contrato

I.S.

$$
[
$$

chefe de governo

C.B.

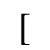

com o Correio ( ) dado como garantia repasso de recurso público para pagar os quarenta milhões que já está pago o PT não deve um tostão mais já está pago já está pago o empréstimo

J.E.C.

o presidente do seu parTIdo Jorge Bornhausen foi

1000

I.S. lembra... do governo Collor? do esquema PC Farias?

miNIStro do governo COllor o senhor não viveu esse período? o o senhor o senhor não

J.E.C.

esqueceu amnésia... amnésia (total)

[

o senhor não lembra do esquema PC

Farias... onde o presidente do seu partido era ministro de EsTAdo... também começou numa promiscuiDAde... deriVAda... do sistema eleitoral? a a memória se apaga não existiu o Collor no Brasil não existiu o o escândalo do governo Fernando Henrique Cardo::so não não o o governo do PFL nunca houve NAda... houve apenas aGOra... ou seja a corrupção nasceu com o PT senador será isso?

C.B.

\section{[}

(tanto existiu) que ( ) agora está tudo igual ao

governo Collor

P.M.

Jo/ José Eduardo... Gustavo

1015 G.F. não nasceu com o PT... mas o que surpreende é que o PT foi eleito para fazer diferente... o PT sempre adotou discurso da prática generalizada de condenação... aos partidos tradicionais aos políticos tradicionais brasileiros... o Brasil mudou em quinze anos... e toda vez que se compare o governo Collor é um perigo... pois há muito mais semelhança do que diferença com isso que está acontecendo agora... e não se pode alegar que é ingenuidade... O responsável pela denúncia por todo esse processo se chama Roberto Jefferson que acusado pelo PT na época do governo Collor... de ser da sua tropa de choque... ou seja o ministro José Dirceu... saBIa com quem estava lidando... não há ingênuo nessa história... e é bom observar... que:: nós não podemos cair nessa armadilha... de generalizar... toda vez que de forma inteligente... o deputado Roberto Jefferson joga essa suspeita... agora... somando-se a suspeita levantada pelo 
1025 governo... se gera uma IDÉia equivocada... de que nós temos que responder sistematicamente...NÃO... cada uma responde pelos seus atos... bem disse a Denise "há políticos muitos sérios que já passaram pelo governo do Brasil”... mas nós temos uma questão concreta

D.F.

1030

J.E.C.

é verdade

G.F. nós temos um contrato... que foi feito por partido... avalizado por empresário... que negou na CPI desrespeito à Comissão Parlamentar de Inquéritos... se descobriu um segundo contrato... e agora vem uma versão... que esse empresário num ato de benevolência... jamais vista na história do Brasil... faz um contrato no sistema privado... brasileiro... de quase quarenta milhões de reais atendendo um pedido de um amigo chamado Delúbio... e esse dinheiro foi utilizado para financiamento eleitoral... nós temos que investigar nesse momento... a origem... a intermediação... e a destinação desse recurso... a reforma política é necessária... CRIse é um momento de se dar um salto... uma oportunidade de purificação

M.R.

isso...concordo

J.E.C.

concordamos

1045

G.F. SEM ilusão... não vai acabar a corrupção no Brasil... como não acabou... em qualquer sistema no MUNdo... mas nós podemos melhorar os meios... de fiscalização isso já ocorreu numa história recente... e Olha... toda vez que se tenta jogar... para o governo passado... se incorre... num grande erro... foi um governo julgado pelo voto popular... e pela primeira vez na história do Brasil... uma série de medidas de mudanças profundas... de ordem... institucional foram realizadas portanto

J.E.C. $\quad[$

mas Fruet

I.S.

mas

G.F. nós temos que ter o olho na questão concreta... pensar como conseqüência... o encaminhamento éh de reformas... que possam melhorar no controle do sistema político brasileiro

I.S. $\quad[$

1060

em seguida Markun

J.E.C. [

só uma parte... breve apeSAR disso... eu acho que não pode haver esse ( ) senador César Borges... há gente boa e gente má em todos os partidos infelizmente... porque os partidos são formados por pessoas... e que se submetem às tentações ou resistem a elas... agora

C.B. 
mas também só havia gente boa do PT

J.E.C.

não deixa eu só concluir senador... um minutinho só senador... eu quero... só concluir... só concluir uma coisinha

1070

M.R.

\section{[} teve irregularidade

J.E.C. tamBÉM do governo do Fernando Henrique Cardoso... FRUto des/ dessa situação estrutural... nós nós tivemos problemas... senador... tivemos a acusação da compra de votos no congresso... tivemos outra/ outras situações de escândalo... o próprio Gustavo Fruet presiDIU a CPI do PROER onde existiam o indício sério de situações irregulares... ou SEja... nós temos que ter claro... que HÁ uma questão... que não se afasta da necessidade de puNIR os que praticam delitos... que é a questão estrutural... essa questão estrutural tem que ser enfrentada sim... com coragem e que aproveitemos a crise para fazer isso

P.M.

(Eduardo) nós precisamos fazer... um intervalo... e vamos continuar discutindo esse assunto... e eu queria antes de chamar o intervalo mostrar... mais algumas opiniões da população da cidade de São Paulo... que de alguma forma reflete... imagino... a opinião dos brasileiros

((apresentação de um filme em que algumas pessoas opinam sobre a crise))

((quarto bloco do programa))

P.M. a pergunta que eu gostaria de colocar... além de:: colocar em debate essas opiniões do público... é a seguinte... é::: são duas na verdade e nós temos um minuto e meio para cada um... se os senhores e as senhoras estão convencidos de que o presidente Lula... NÃO sabia de nada sobre a corrupção e eMENdo... será que isso não é TÃO GRAve quanto saBER? Gustavo

G.F. tem razão Markun... o presidente hoje está na seguinte situação... de um Lado... se ele sabia muito grave... e eu lembro que ex-ministro José Dirceu antes de sair... de forma TAxativa afirmou... "tudo que fazia Era do conhecimento do presidente da República" se do outro lado... ele não sabia... também é muito grave... porque de um presidente se espera algo mais do que ficar indignado e chorar... de um presidente se espera liderança... para que num momento de crise tomar atitude... nem que se signifique tomar decisões na própria carne... o Roberto Jefferson foi responsável... pela maior reforma ministerial... DEsse governo... o presidente poderia ter se antecipado... já na denúncia do Valdomiro Diniz... paSSOU... é o tempo que vai julgá-lo... principalmente o eleitor no ano que vem... mas nessa Hora... até para tranqüilizar os ouvintes... e os telespectadores... a investigação tomou uma dinâmica... que independe de qualquer tentativa de abafá-la... de resistência... ou até... generalizar idéia... de que todos são iguais todos os partidos são iguais... eu não caiu na armadilha de toda vez ter que defender pelas minhas atitudes... como fazem muitos parlamentares... que estão aqui também em defenderem suas posições... mas sem ficarem caindo nessa armadilha... de aceitar essas provocações... é o tempo que irá julgar cada um de nós... nós seremos julgados pelos resultados da CPI... mas em cima de um caso concreto... a reforma política... o financiamento público... pode ser uma conseqüência de melhora... mas nós estamos investigando uma denúncia... dentro da base aliAda... DO governo... envolvendo lideranças... proFUNdamente ligadas... ao presidente da República... que prometeu fazer diferente... para encerrar eu lembro do meu pai... nessa hora... ele dizia... o seguinte "quando a esperteza é muito grande vira bicho e come esperto" e tem muito esperto nessa história... que está enganando a sua história... a história do Partido dos Trabalhadores... que tem uma das histórias mais bonitas da democracia... brasileira mas que hoje vive um momento... de divisor de águas... tem a 
oportunidade de dar um salto... mas também... tem a oportunidade de mostrar para o Brasil... e reconhecer os Erros... nas suas composições... e na forma proMíScua... de relação com o Congresso Nacional

P.M. José Eduardo

J.E.C. eu acredito que:: o presidente Lula não TEM nenhum envolvimento com esses fatos... e acho:: é:: muito ruim imaginar que o presidente da República Markun... tenha que ter ciência de TUdo que acontece no uniVERso administrativo senão ele será um incompetente...por diVERsas vezes durante o governo o Fernando Henrique Cardoso... situações também ocorreram... e Fernando Henrique Cardoso tenho certeza absoluta não saBIa de CERtas situações que lá esTAvam colocadas... e ele... evidentemente não vai ser colocado nem por você Fruet ((olha e aponta para o deputado)) nem por ninguém como alguém que deveria saber e é incompetente por isso... então diante DEsse QUAdro... ((olha para câmera)) eu tenho CERteza que o presidente está preserVAdo... rigorosamente preservado desse escândalo e tem dados sinais muito CLAros na LInha é:: disso como disse "invesTIR em mim... vamos cortar na própria CARne” que é o coMANdo que ele tem dado a nós... e nós vamos seguir isso fielmente porque o PT construiu...durante vinte e cinco anos um patrimônio ético... e eu não tenho a menor dúvida... que a melhor maneira de nós mantermos esse patrimônio... é cortamos como diz o presidente "na carne"... assim que se comprovar o envolvimento de alGUÉM... do PT... militante dirigente parlamentar... ( ) nós temos que ser INtolerantes com aqueles que transgridem a ética e até tenho dito mais Markun... nós temos que ser TÃO ou MAIS intolerantes com aqueles do PT que transgridem a ética... do que nós fomos no paSSAdo com nossos adversários... portanto eu acho que::: é:: o PT tem que nesse momento um momento difícil sem dúvida... mas é um momento... DIferencial da nossa história...se nós mostrarmos com clareza o que nós queremos que é investiGAR e punir... pessoas que estão envolvidas no NOsso campo... eu tenho certeza absoluta que o nosso patrimônio ético sai RI-go-ro-sa-men-te ( ) ....apesar...de todo esse momento difícil que nós vivemos.

1140 P.M. Denise

D.F. infelizmente eu não tenho:: a posição dos dois... gostaria de TÊ-la... mas ontem eu a perdi... realmente se havia...algo/ uma dúvida com o presidente agora EU já não Tenho... porque ele veio a público Markun...não pra dar explicações...mas para convaliDAR e justifiCAR...as explicações de Valério e Delúbio...reitero o que eu disse aqui... gostaRI::a de não acreditar nisso... MAS ONtem quando ele falou eu passei a creditar nisso... e eu acho sinCEramente... que o presidente TEM que SER in-ves-ti-ga-do aGOra... ele ah: ele se joGOU...DENtro do proCEsso ((aponta para baixo onde há um cenário que representa um rio de lama)) e aí?...como é que FIca...o presidente que joga os seus três melhores ministros DENtro do partido... depois de ter...aPArelhado o EsTA::do...eu se fosse do PT e teria muita honra... tenho grandes amigos lá estão aqui o Rands... o Cardoso conheci a Deli agora... mas:....eu SINto que vários amigos meus foram angaNAdos... enganados por uma cúpula... que capturou...o es-TA-do...bra-si-LEI-ro...numa organização crimiNO::sa sim... e o fim era capturar o Estado... e por isso uSAram o crime de corrupção... inclusive a lavagem de dinheiro... lamen::to mas não imPULto ao PT... eu impulto a uma CÚpula... igual aquele que eu julguei...há treze anos atrás

\section{P.M. Ideli Salvatti}

I.S. em primeiro lugar eu queria deixar assim claro que o presidente Lula ah:: ele... tem... consciência... sempre teve... como nós do PT sempre tivemos... de que a corrupção é algo:: que está entranhado na máquina pública está:: é algo q/ eu sempre brinco né... como como mulher... que está encardido né... está encardido no tecido da máquina pública brasileira... e foi por isso que o presidente Lula... adotou uma série de medidas e orientações e:: ah:: orientações muito CLAras ah:: no seu governo... na estrutura de governo... através do Ministério da Justiça... através das ações da Polícia Federal... através da Controladoria Geral da União... para que nós pudéssemos ter uma série de:: operações de ações... e de modificações... inclusive 
legislativas que partiram né da da iniciativa do próprio governo no sentido de combater... e de reestruturar a máquina pública... na lógica de fazer o combate a corrupção... por isso que o presidente que tem dado uma demonstração clara... e as pessoas enxergam isso as pessoas vêem isso... as pessoas têm a VIsibilidade do combate à corrupção... através das ações claras que o governo desenvolveu ao longo desses dois anos e meio... é por isso que quando sai a pesquisa... a população não enxerga... o envolvimento do presidente a população é continua confiante no presidente... a população... ah quando é perguntada inclusive qual é a pessoa mais ah preparada para combater a corrupção? como apareceu agora na ( CNT Sensius) aparece o presidente Lula... então é por isso que para nós... ah não há nenhuma nenhuma ah prova... nada... que possa colocar... até porque o presidente deu TOdas as demonstrações até agora desse compromisso no combate a corrupção... e assim que a população ah vê e é dessa forma que nós estamos trabalhando sob a orientação dele... de combater... de investigar... e de punir... tudo e todos que estejam envolvidos com a corrupção... incluSIve... e talvez eu diria até... PRIoritariamente os nossos porque nós temos que dar o exemplo

\section{P.M. César Borges}

1180 C.B. Markun eu acho que:: o PT cometeu um grave equívoco... quando como partido... procurou aparelhar o governo... com os seus correligionários sem olhar para o mérito... nem a qualidade... daqueles que assumiriam a responsabilidade de governar o país... indicar apenas se tinha sido sindicalis::ta há tantos anos... se tinha sido mais ou menos fiel ao governo... com isso fizeram o aparelhamento que ficou extremamente difícil... o controle por parte do presidente da República... mas eu acho que quem... efetivamente... é o maior responsável é o presidente da República... nada seria feito sem a sua autorização... inclusive com a relação a saber ou não do mensalão... a própria revista Veja dessa semana traz cinco oportunidades onde ele foi informado... e veja bem o presidente não desmentiu em momento nenhum... o Roberto Jefferson disse que falou duas vezes com ele... apenas disseram que não foram duas... foi uma vez... mas falou... e nenhu::ma providência foi tomada então isso constitui-se um crime... de responsabilidade... e esse aparelhamento foi extremamente prejudicial a gestão:: administrativa do governo... e faciliTOU... que acontecesse as questões que estão acontecendo e os escândalos se... resumem aos Correios... se você/ vou dar mais uma vez o exemplo da Veja... você tem o Banco do Brasil... Henrique Pizzolato... o Banco do Brasil gastou no ano de

1195 dois mil e quatro duzentos e quarenta milhões de reais de publicidade... quem é a agência? SMP\&B né... então o tempo é curto eu vou encerrar... mas nós temos o problema do GameCorp também que é outra denúncia grave a ser apurada de tráfico de influência... então há com gran::de tráfico de influência... DENtro deste governo prejudicial a gestão da coisa pública no país... mas que o presidente tem responsabilidade TEM

\section{P.M. Maurício Hands}

M.R. sabe qual é a diferença? é que este governo... sabedor da realidade do EsTAdo brasileiro... o que surge... o que tem de denúncia... ele manda apurar... eu vejo infelizmente mui::to jogo de cena... eu vejo lá quantas CPIs lá no governo do governador César Borges foram permitidas na Assembléia Legislativa ou de outro modo quantas foram abafadas...esse governo e aí a senadora Ideli Salvatti está muito correta... TOdas as denúncias que surgem este governo está investigando... por isso foi aquele que fez MAIS operação da Polícia Federal... aquele que fortaleceu a Controladoria Geral da União... aquele que está indo a fundo... e cortando na própria carne... então o presidente da República sabe o povo brasileiro sabemos todos nós aqui... a não ser que queiramos fazer cena política... o povo brasileiro SAbe... que o presidente Lula não tinha conhecimento de de desvios que foram cometidos nesses financiamentos de eleição... e por isso Ele como todos nós estamos empenhados a punir... punir quem seja do PT que tenha cometido irregularidade... que seja da oposição... que seja de partido da base aliada... agora ficam algumas lições... em primeiro lugar... não se pode generalizar não se pode tirar... o todo pela parte... este Partido dos Trabalhadores é um partido com oitocentos e em si... a transformação e a inserção do povo na disputa política... e portanto fica essa grande 
lição que... quando nós votarmos... para o Executivo... mas precisamos votar também... para o Legislativo... porque um dos problemas... foi a necessidade que teve o presidente Lula... de fazer alianças que incorreram em métodos da política tradicional... então nós vamos... depurar... corrigir... punir... no partido... ou fora do partido... TOdos aqueles que tenham cometido irregularidades... nós queremos a verDAde... passar a limpo as instituições... estaTAIS e políticas desse país

P.M. bem nosso tempo acabou e eu queria deixar registrado uma coisa que não é:: não é digamos... mérito... meu nem mesmo da equipe que trabalha comigo porque televisão não se faz sozinho... mas é mérito da TV Cultura... que há deZOIto anos produz este programa semanalmente... e transforma este programa sempre num fórum de deBAtes seja... ele nesse formato de hoje... de um debate aceso e:: envolvendo pessoas com posições divergentes... seja no formato de entrevista coletiva que acontece toda segunda-feira... é que este programa está registrado para história... e daqui dezoito daqui a vinte trinta anos... nós vamos ter condição de reexamiNAR... o que aqui se passou... e quem tinha a razão... esse é o dado positivo e é o que pode contribuir... a TV Cultura... com o seu compromisso de jornalismo público... com o seu compromisso... de debater e discutir... abertamente... democraticamente as questões... espero que a gente tenha $\mathrm{co} / \mathrm{com} /$ conseguido botar mais $\mathrm{um} / . .$. uma areiazinha... ne::sse prato hoje a noite... agradeço a presença dos nossos debatedores a você que está em casa... e convidá-lo a estar aqui na próxima segunda-feira... com mais um Roda Viva... uma ótima semana e até lá 